Prepared in cooperation with the Bureau of Reclamation and the U.S. Fish and Wildlife Service

\title{
Effects of Groundwater Pumping on Agricultural Drains in the Tule Lake Subbasin, Oregon and California
}

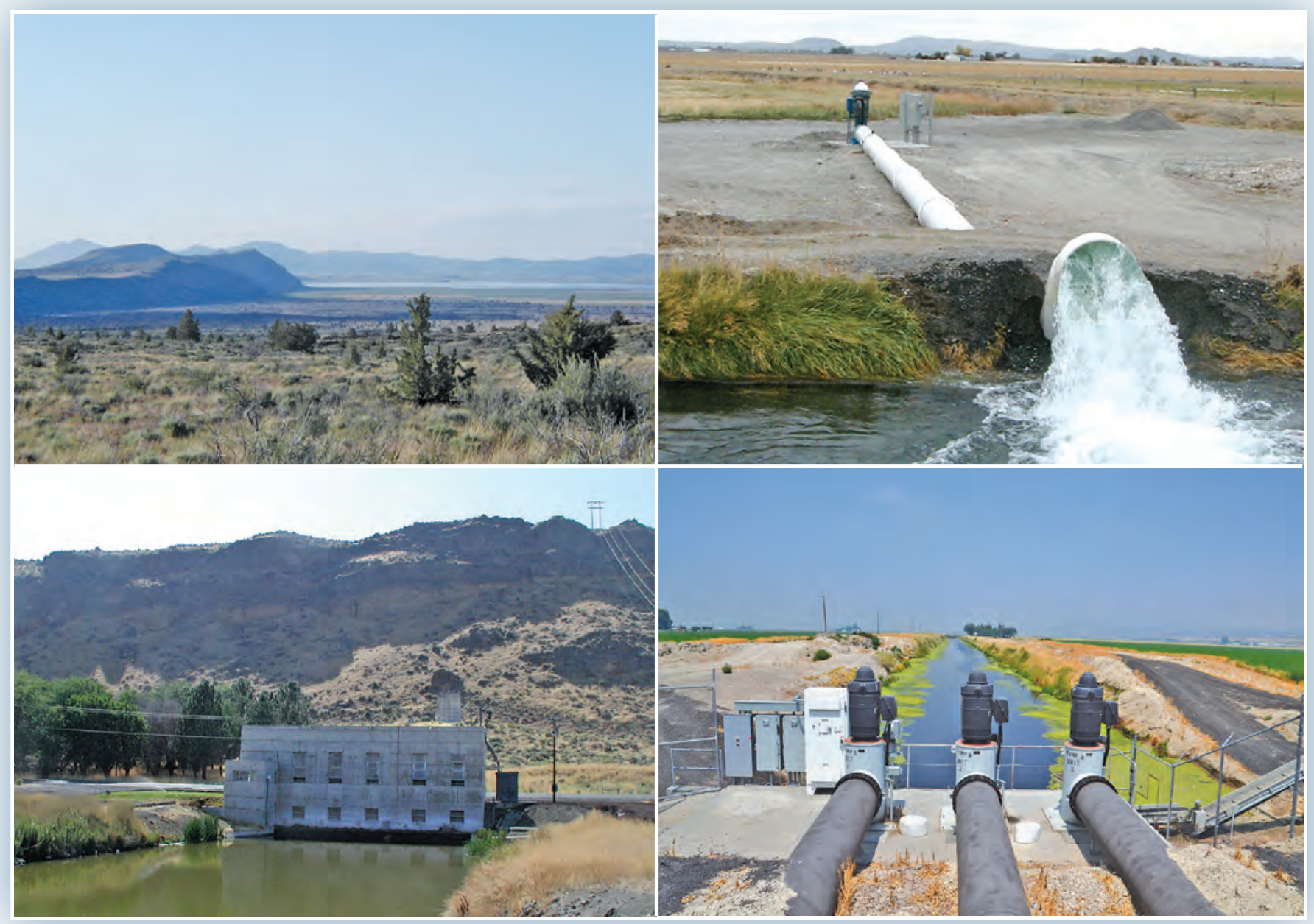

Scientific Investigations Report 2015-5087 


\section{Cover:}

Top left: Sheepy Ridge and the Tule Lake subbasin as seen looking north from Lava Beds National Monument, California. (Photograph by Marshall Gannett, U.S. Geological Survey.)

Top right: Pump A motors, with Drain 46 in background, Tulelake Irrigation District, Oregon and California. (Photograph taken by Brian Wagner, U.S. Geological Survey.)

Bottom left: Tulelake Irrigation District irrigation well 1 pumping into a canal, California. (Photograph by Marshall Gannett, U.S. Geological Survey.)

Bottom right: Pumping Plant D, looking west toward Sheepy Ridge, Tulelake Irrigation District, Oregon and California. (Photograph by Marshall Gannett, U.S. Geological Survey.) 


\section{Effects of Groundwater Pumping on Agricultural Drains in the Tule Lake Subbasin, Oregon and California}

By Esther M. Pischel and Marshall W. Gannett

Prepared in cooperation with the Bureau of Reclamation and the U.S. Fish and Wildlife Service

Scientific Investigations Report 2015-5087 


\title{
U.S. Department of the Interior SALLY JEWELL, Secretary
}

\section{U.S. Geological Survey \\ Suzette M. Kimball, Acting Director}

\author{
U.S. Geological Survey, Reston, Virginia: 2015
}

For more information on the USGS - the Federal source for science about the Earth, its natural and living resources, natural hazards, and the environment—visit http://www.usgs.gov or call 1-888-ASK-USGS.

For an overview of USGS information products, including maps, imagery, and publications, visit http://www.usgs.gov/pubprod/.

Any use of trade, firm, or product names is for descriptive purposes only and does not imply endorsement by the U.S. Government.

Although this information product, for the most part, is in the public domain, it also may contain copyrighted materials as noted in the text. Permission to reproduce copyrighted items must be secured from the copyright owner.

Suggested citation:

Pischel, E.M., and Gannett, M.W., 2015, Effects of groundwater pumping on agricultural drains in the Tule Lake subbasin, Oregon and California: U.S. Geological Survey Scientific Investigations Report 2015-5087, 44 p., http://dx.doi.org/10.3133/sir20155087.

ISSN 2328-0328 (online) 


\section{Contents}

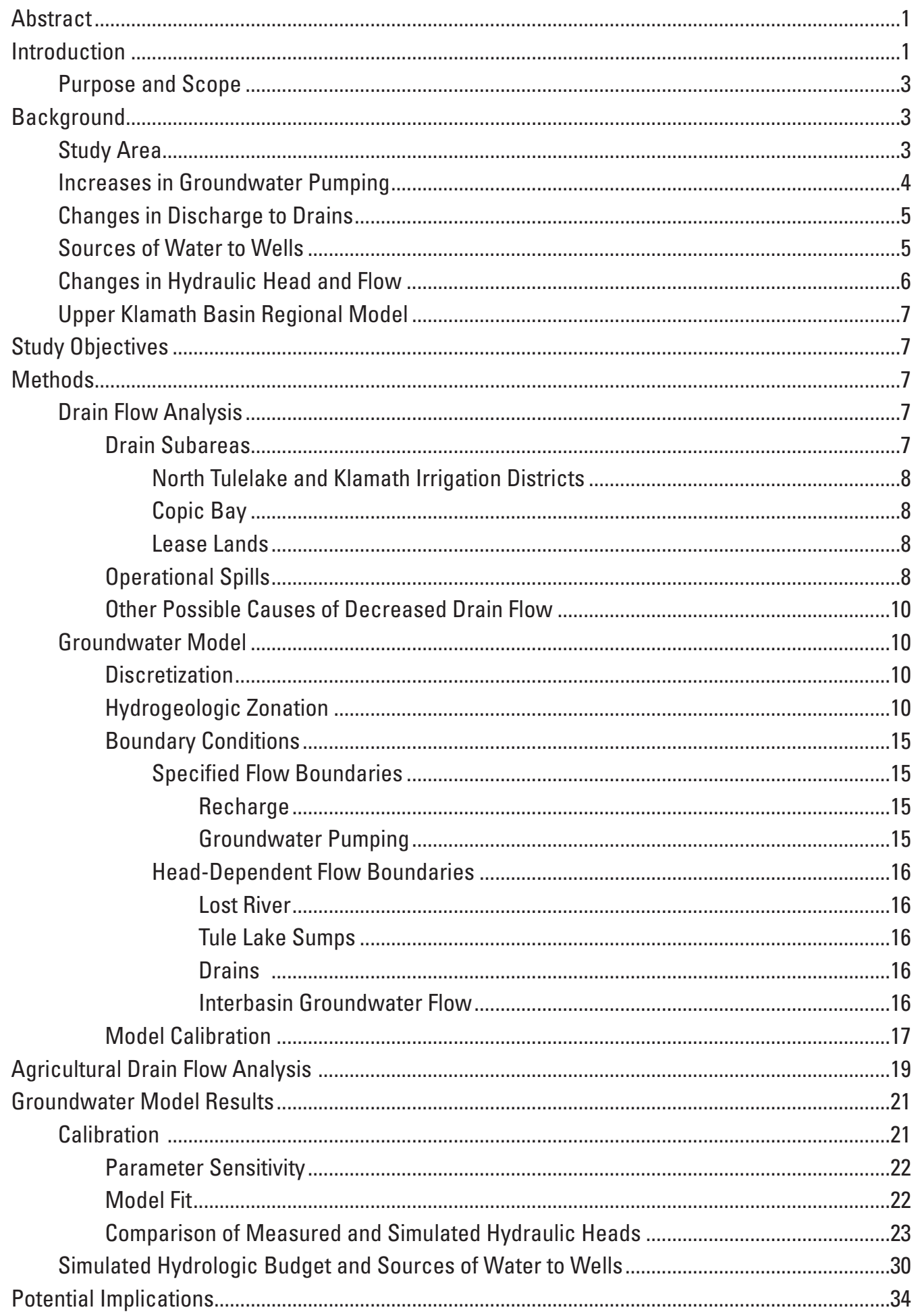




\section{Contents-Continued}

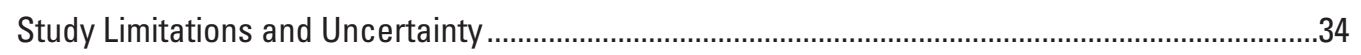

Uncertainty in the Drain-Flow Analysis ..............................................................................

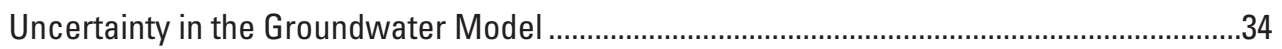

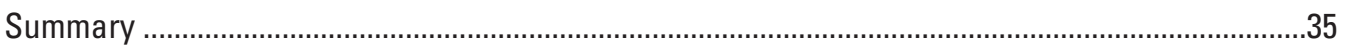

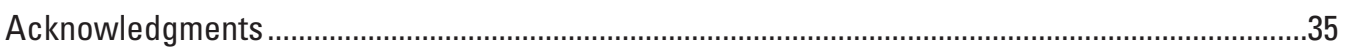

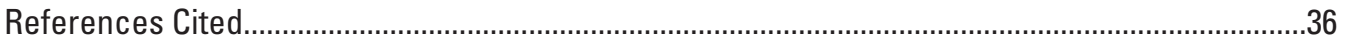

Appendix A. Model Observation Wells …………………..............................................................

\section{Figures}

1. Map showing Tule Lake study area of the upper Klamath Basin, Oregon and California

2. Photograph showing example of an agricultural drain in the Tule Lake subbasin, California

3. Graph showing total diversions, D Plant pumpage, and ratio of D Plant pumpage to total diversions, Tule Lake subbasin, Oregon and California, 1961-2011 ......5

4. Hydrographs showing four observation wells in the Tule Lake subbasin, California .......6

5. Photograph showing example of a drain pump in the Tulelake Irrigation District

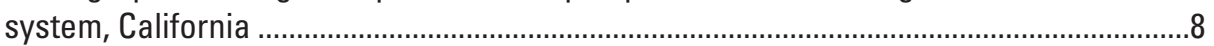

6. Map showing subareas and drain pumps used in analysis of drain flow, Tule Lake subbasin, Oregon and California .........................................................................

7. Map showing groundwater-model grid and boundary conditions, Tule Lake subbasin, Oregon and California.....

8. Maps showing hydrogeologic zonation of the Tule Lake groundwater model, Tule Lake subbasin, Oregon and California..

9. Cross sections of Tule Lake groundwater model, Tule Lake subbasin, Oregon and California

10. Map showing locations of observation wells for the Tule Lake subbasin model, Oregon and California

11. Graph showing yearly volume of water from pumps integrating the North Tulelake and Klamath Irrigation District (TID/KID) subarea, Oregon and California .......20

12. Graph showing yearly volume of water from pumps integrating the Copic Bay subarea, Tule Lake subbasin, California

13. Graph showing yearly volume of water from pumps integrating the Lease Lands subarea, Tule Lake subbasin, California 


\section{Figures-Continued}

14. Graph showing composite scaled sensitivities of parameters in the Tule Lake groundwater model.

15. Graph showing weighted residuals and weighted simulated hydraulic head values, Tule Lake subbasin, Oregon and California

16. Graphs showing observed and simulated hydraulic heads for selected observation wells, Tule Lake subbasin, Oregon and California

17. Graphs showing water levels in U.S. Geological Survey observation wells 430837121473201 (28.00S/08.00E-17DBC01), about 80 miles north-northwest of the Tule Lake subbasin, and 414043121155501 (44.00N/06.00E-03P01M), about 10 miles southeast of the Tule Lake subbasin, Oregon and California

18. Graph showing observed and simulated decrease in flow to drains relative to drain flow in 2000, Tule Lake subbasin, Oregon and California

19. Graph showing simulated water budget components of the Tule Lake subbasin, Oregon and California

20. Graph showing simulated cumulative change in volume of selected budget components of the Tule Lake subbasin, Oregon and California

21. Map showing spatial distribution of simulated reduction in discharge to drains, calculated as the discharge to drains in 2006 subtracted from the discharge to drains in 2000, Tule Lake subbasin, Oregon and California

\section{Tables}

1. Layer thicknesses for the Tule Lake groundwater model.............................................10

2. MODFLOW-2000 packages and files used in the Tule Lake subbasin model ...................17

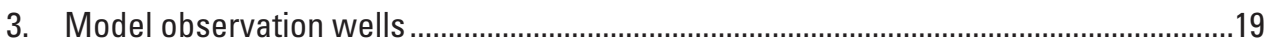

4. Calibrated values of parameters for the Tule Lake subbasin groundwater flow model, Oregon and California .

5. Simulated cumulative change in volumetric budget, Tule Lake subbasin, Oregon and California 


\section{Conversion Factors}

Inch/Pound to International System of Units

\begin{tabular}{|c|c|c|}
\hline Multiply & By & To obtain \\
\hline \multicolumn{3}{|c|}{ Length } \\
\hline foot $(\mathrm{ft})$ & 0.3048 & meter (m) \\
\hline mile (mi) & 1.609 & kilometer (km) \\
\hline \multicolumn{3}{|c|}{ Area } \\
\hline acre & 0.4047 & hectare (ha) \\
\hline acre & 0.004047 & square kilometer $\left(\mathrm{km}^{2}\right)$ \\
\hline square foot $\left(\mathrm{ft}^{2}\right)$ & 929.0 & square centimeter $\left(\mathrm{cm}^{2}\right)$ \\
\hline square foot $\left(\mathrm{ft}^{2}\right)$ & 0.09290 & square meter $\left(\mathrm{m}^{2}\right)$ \\
\hline \multicolumn{3}{|c|}{ Volume } \\
\hline acre-foot (acre-ft) & 1,233 & cubic meter $\left(\mathrm{m}^{3}\right)$ \\
\hline \multicolumn{3}{|c|}{ Flow rate } \\
\hline acre-foot per year (acre-ft/yr) & 1,233 & cubic meter per year (m³/yr) \\
\hline acre-foot per year (acre-ft/yr) & 0.001233 & cubic hectometer per year $\left(\mathrm{hm}^{3} / \mathrm{yr}\right)$ \\
\hline foot per second $(\mathrm{ft} / \mathrm{s})$ & 0.3048 & meter per second $(\mathrm{m} / \mathrm{s})$ \\
\hline foot per year (ft/yr) & 0.3048 & meter per year $(\mathrm{m} / \mathrm{yr})$ \\
\hline cubic foot per second $\left(\mathrm{ft}^{3} / \mathrm{s}\right)$ & 0.02832 & cubic meter per second (m³/s) \\
\hline
\end{tabular}

\section{Datums}

Vertical coordinate information is referenced to the National Geodetic Vertical Datum of 1929 (NGVD 29).

Horizontal coordinate information is referenced to the North American Datum of 1927 (NAD 27).

Elevation, as used in this report, refers to distance above the vertical datum. 


\title{
Effects of Groundwater Pumping on Agricultural Drains in the Tule Lake Subbasin, Oregon and California
}

\author{
By Esther M. Pischel and Marshall W. Gannett
}

\section{Abstract}

Since 2001, irrigators in the upper Klamath Basin have increasingly turned to groundwater to compensate for reductions in surface-water allocation caused by shifts from irrigation use to instream flows for Endangered Species Act listed fishes. The largest increase in groundwater pumping has been in and around the Bureau of Reclamation's Klamath Irrigation Project, which includes the Tule Lake subbasin in the southern part of the upper Klamath Basin. Agricultural drains on the Klamath Project are an important source of water for downstream irrigators and for the Tule Lake and Lower Klamath Lake National Wildlife Refuges. U.S. Geological Survey regional groundwater-flow model simulations and records of irrigation-return flow pumped from the Tule Lake subbasin into the adjacent Lower Klamath Lake subbasin have indicated that water-level declines from pumping may be causing decreased flow of shallow groundwater to agricultural drains.

To better define the effect of increased pumping on drain flow and on the water balance of the groundwater system, the annual water volume pumped from drains in three subareas of the Tule Lake subbasin was estimated and a fine-grid, local groundwater model of the Tule Lake subbasin was constructed. Results of the agricultural-drain flow analysis indicate that groundwater discharge to drains has decreased such that flows in 2012 were approximately 32,400 acre-ft less than the 1997-2000 average flow. This decrease was concentrated in the northern and southeastern parts of the subbasin, which corresponds with the areas of greatest groundwater pumping. Model simulation results of the Tule Lake subbasin groundwater model indicate that increased supplemental pumping is the dominant stress to the groundwater system in the subbasin. Simulated supplemental pumping and decreased recharge from irrigation between 2000 and 2010 totaled 323,573 acre-ft, 234,800 acre-ft (73 percent) of which was from supplemental pumping. The response of the groundwater system to this change in stress included about 180,500 acre-ft (56 percent) of decreased groundwater discharge to drains and a 126,000 acre-ft
(39 percent) reduction in aquifer storage. The remaining 5 percent came from reduced groundwater flow to other model boundaries, including the Lost River, the Tule Lake sumps, and interbasin flow.

\section{Introduction}

The allocation of water between agriculture and aquatic wildlife has been challenging for resource managers in the upper Klamath Basin of southern Oregon and northern California (fig. 1). In 2001, drought conditions resulted in nearly all of the available water in the Upper Klamath Basin being reallocated to maintain water levels in Upper Klamath Lake to protect the endangered Lost River and shortnose suckers, and to maintain flows in the Klamath River to protect the threatened coho salmon (National Research Council, 2004). In response to this reallocation of water, irrigators have increasingly turned to groundwater to offset the shortages in surface water availability. The largest increase has been in and around the Bureau of Reclamation's Klamath Irrigation Project (Project), which includes the Tule Lake subbasin in the southern part of the upper Klamath Basin (Gannett and others, 2007).

Groundwater pumping has resulted in water-level declines in wells near the centers of pumping, which affects directions and rates of groundwater flow. Results of U.S. Geological Survey (USGS) groundwater modeling efforts (Gannett and others, 2012), analysis of monitoring well data, and hydrologic budget information from the Bureau of Reclamation and irrigation districts that operate in the Tule Lake subbasin indicate that pumping-related hydraulic head changes may be resulting in decreased flow to agricultural drains. The lowering of hydraulic heads in aquifers may be inducing downward flow of shallow groundwater, decreasing lateral flow toward drains. Decreased shallow groundwater discharge to agricultural drains has potential implications for Project operations and for water supplies to the Tule Lake and Lower Klamath National Wildlife Refuges. 


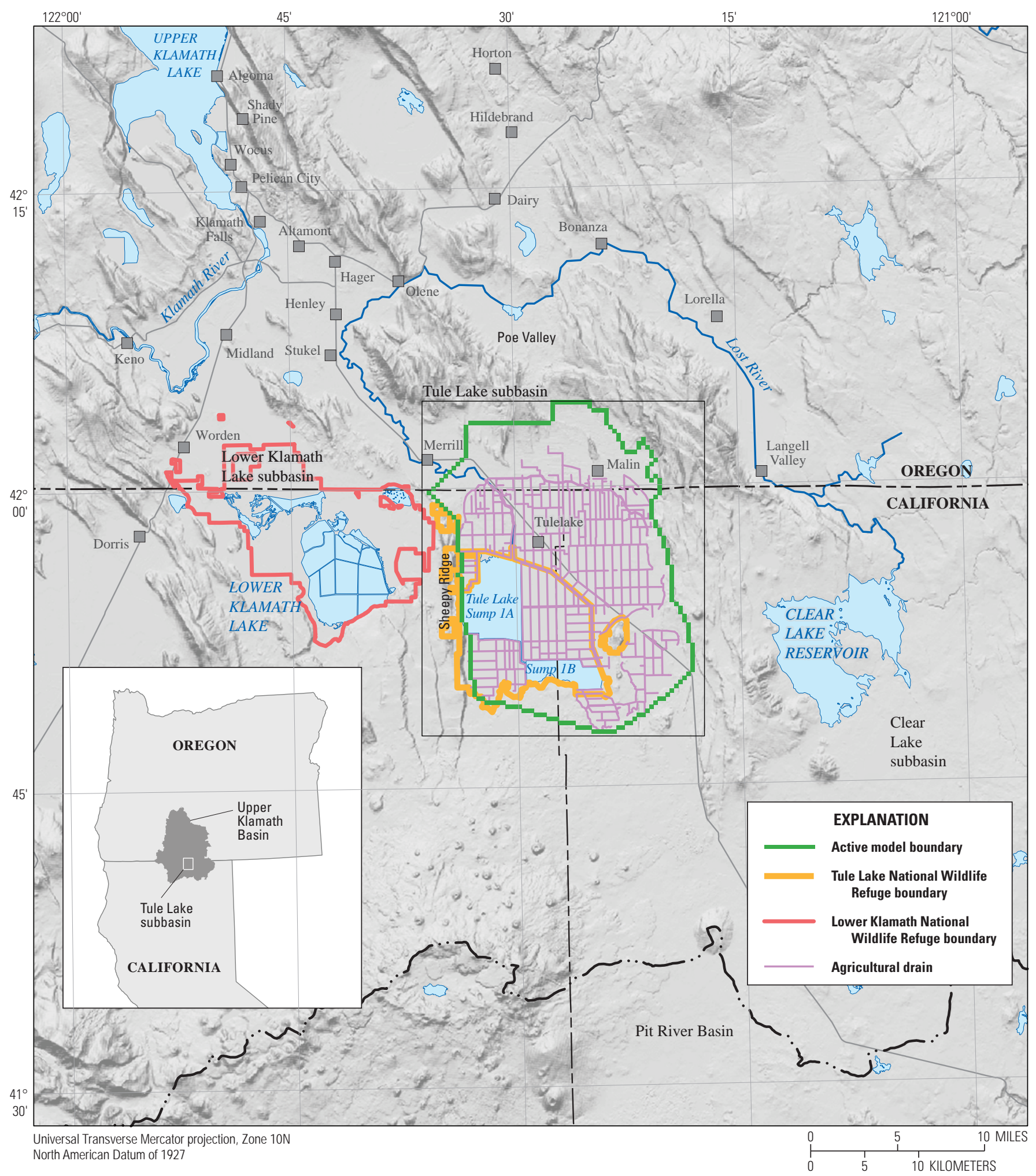

Figure 1. Tule Lake study area of the upper Klamath Basin, Oregon and California. 


\section{Purpose and Scope}

This report presents the results of a cooperative study with the Bureau of Reclamation and U.S. Fish and Wildlife Service to develop a quantitative understanding of the connection between volcanic and overlying sedimentary aquifers in the Tule Lake subbasin of the upper Klamath Basin to assess the effect of pumping on agricultural drains. As part of that goal, data on diversions, operational spills, and drain flows from irrigation districts that serve the Tule Lake subbasin were analyzed to evaluate changes in the water balance of the subbasin. Additionally, a groundwater-flow model of the Tule Lake subbasin was developed to integrate knowledge about the groundwater hydrology of the subbasin and to explore the degree to which increased groundwater pumping may be affecting flow in drains.

\section{Background}

\section{Study Area}

The Tule Lake subbasin is in the southeastern part of the upper Klamath Basin and straddles the Oregon-California border (fig. 1). Prior to development, the Tule Lake subbasin contained a large lake with an area exceeding 96,000 acres fringed by extensive wetlands. In 1912, a canal and dam were constructed to divert the flow of the Lost River to the Klamath River, cutting off inflow to Tule Lake (LaRue, 1922). Much of the lake was drained and is now under cultivation. The Tule Lake subbasin is a structural basin created by faulting of middle to late Tertiary volcanic rocks. The basin has been filled with predominantly fine-grained sediment to depths locally exceeding $1,800 \mathrm{ft}$. The basin-filling sediment is saturated, and wells that produce from it have modest yields because of low to moderate permeability. Beneath the sediment, the basin is underlain by a thick sequence of highly permeable basaltic lava flows that are also saturated. Wells in the underlying lava generally produce large volumes of water suitable for irrigation. At the southern edge of the Tule Lake subbasin, permeable Quaternary lava flows and vent deposits overlie and are interbedded with the upper parts of the basin-filling sediment (Gannett and others, 2007). Aquifers within these Quaternary volcanic deposits are also used for irrigation.

In this report, the low-permeability basin-fill sediment will be referred to as the "sedimentary aquifer," and the high-permeability basalt lava flows underlying the basinfill sediment will be referred to as the "deep volcanic aquifer." The Quaternary volcanics at the southern edge of the Tule Lake subbasin will be referred to as the "shallow volcanic aquifer.”

Much of the Tule Lake subbasin is within boundaries of the Project, which is irrigated with water primarily from Upper Klamath Lake. Water diverted from Upper Klamath Lake is transferred through a series of canals and applied to crops in large areas of the lower Lost River Basin and Tule Lake subbasin. The Tule Lake subbasin includes the Klamath Irrigation District (KID) and Tulelake Irrigation District (TID). A certain amount of the diverted water is lost through canal leakage during transmission and through deep percolation in fields, recharging the shallow parts of the groundwater system. Generally, the land gently slopes toward the Tule Lake sumps, which are the ultimate collectors of irrigation tailwater in the subbasin.

In addition to supply canals, the Project area is crisscrossed by agricultural drains. Agricultural drains accumulate excess water that has percolated to the shallow subsurface. If this water were not collected in the drains and pumped out, soils in the basin would become saturated and unsuitable for farming. Drains in the Project area are generally large open ditches extending roughly $10 \mathrm{ft}$ below land surface and commonly extending laterally many hundreds or thousands of feet (fig. 2). In contrast, canals are generally at elevations above land surface to allow gravity flow to fields.

Water enters the drain system as groundwater discharge from shallow flow within the soil (interflow) or as overland surface flow. Shallow groundwater discharging to drains begins either as precipitation, as applied irrigation water, or as water that seeped from the canal system. Water applied to crops generally either returns to the atmosphere through evapotranspiration (ET) or percolates beneath the root zone and recharges the shallow parts of the groundwater system.

Once in the shallow parts of the Tule Lake subbasin groundwater system, water flows either laterally and discharges to the network of agricultural drains, or vertically through the shallow sedimentary aquifer to the underlying volcanic aquifer. Comparison of water levels in shallow and deep wells indicates that there are no upward gradients in the groundwater system. (Eaves and others, California Department of Water Resources, unpub. data, 2002; Gannett and others, 2007). Lateral flow in deeper volcanic deposits is toward the southern boundary of the basin (Gannett and others, 2007). A local connection between the shallow and deep aquifers is evidenced by the response of water levels in the deep volcanic aquifer to the onset of canal operation each spring (Palmer and others, 2006; Gannett and others, 2007). Isotopic analysis of groundwater in aquifers supplying deep irrigation wells in the subbasin also suggests a hydraulic connection between the shallow and deep aquifer (Palmer and others, 2006).

Another source of water to agricultural drains is operational spill, which occurs in the transition between the KID (which irrigates the northern part of the Tule Lake subbasin in Oregon) and the TID (which irrigates within the rest of the subbasin). Operational spill is excess water that must be discharged at the end of a conveyance system when the flow in the system exceeds demand. Operational spills occur because districts may keep more water in supply canals than needed at a given time to provide a buffer for the variable demands of water users. Operational spill from the KID is discharged to the TID drain system at the boundary between two districts, roughly at the State line. 


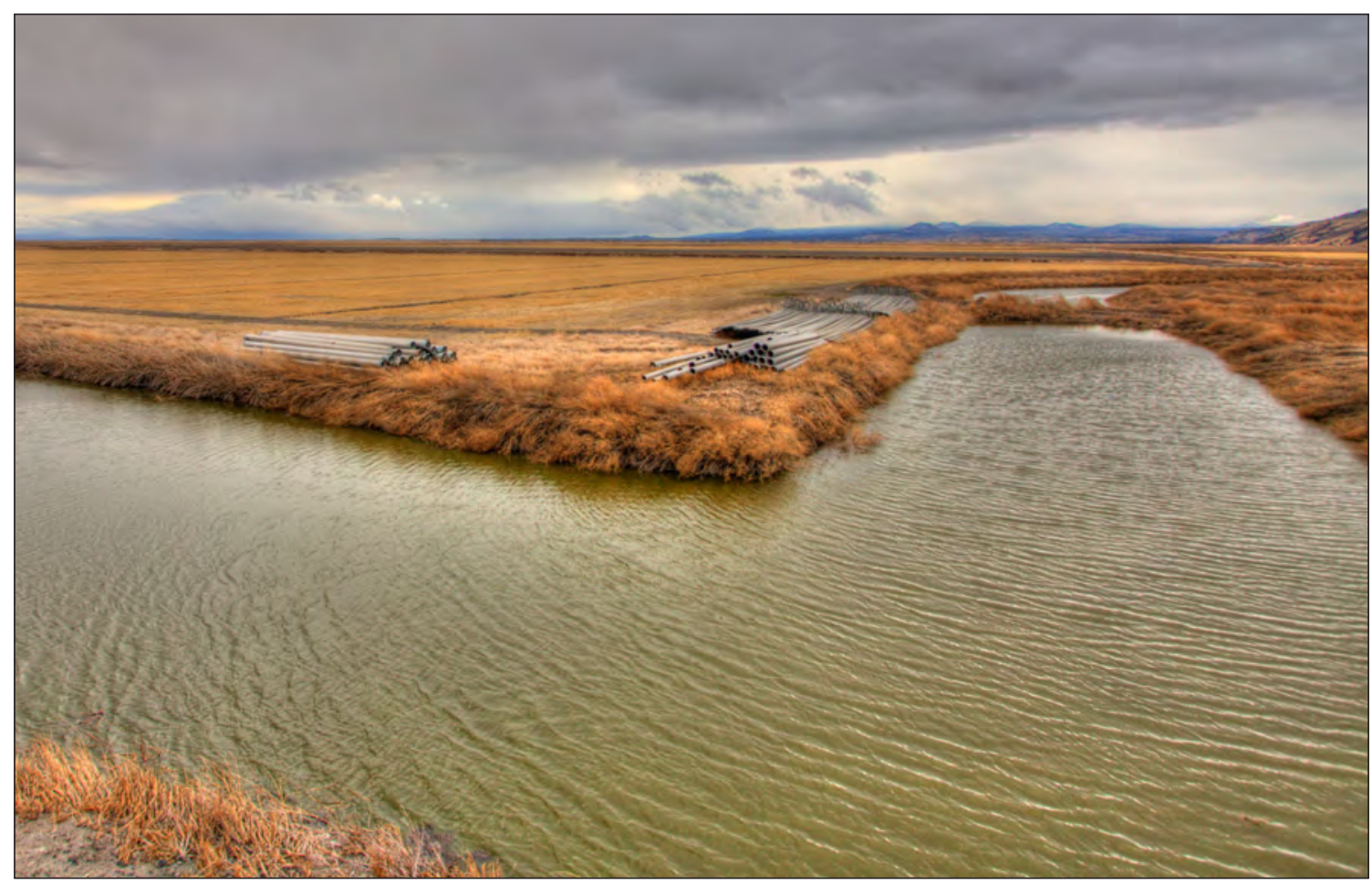

Figure 2. Example of an agricultural drain in the Tule Lake subbasin, California. Photograph taken by Ben Perkins, Portland State University, March 29, 2012. Used with permission.

Water in the drain system either gets pumped back into the distribution canal system or flows to the Tule Lake sump system, the remnant of Tule Lake. The Tule Lake sumps consist of two interconnected lakes that are located in the southern and western parts of the basin, called Sump 1A and Sump 1B (fig. 1). Since 1942, water from the sumps has been pumped by Pumping Plant D (D Plant) through a tunnel in Sheepy Ridge, westward into the Lower Klamath Lake subbasin (fig. 1). Large parts of the TID rely on drain flows for their irrigation supply. Additionally, water that drains to the Tule Lake sumps is a critical part of the water supply for the Tule Lake and Lower Klamath Lake National Wildlife Refuges (fig. 1), comprising 75 and 67 percent of each refuge's total inflow, respectively (Risley and Gannett, 2006). A change in shallow groundwater discharge to agricultural drains, therefore, has consequences for the irrigation project and for water management of the refuge system. Part of the water pumped to the Lower Klamath Lake Refuge is eventually returned to the Klamath River.

\section{Increases in Groundwater Pumping}

Since 2001, groundwater pumping has increased in the Upper Klamath Basin in response to changes in surfacewater management and to a series of drier-than-average years. Much of this increase was related to programs to supplement pumping for the Project. In 2000, total pumping in the upper Klamath Basin was estimated to be 150,000 acre-ft (not including supplemental pumping in Oregon). Additional pumping for the Project began in 2001 and reached 75,800 acre-ft by 2004 . Of this additional pumping, 61,000 acre-ft took place in the Lower Klamath Lake subbasin and lower Lost River drainage, which includes the Tule Lake subbasin (Gannett and others, 2007). Supplemental groundwater pumping continued through 2007. No reported Project-sponsored supplemental groundwater pumping occurred in 2008 and 2009, but drought conditions in 2010 resulted in supplemental pumping of more than 100,000 acre-ft. 


\section{Changes in Discharge to Drains}

Monthly TID records of total flows for diversions, pump stations, and canals for the Project are of particular importance to the analysis of the change in drain flows. Chief among the pumping stations is the D Plant, which lifts water from the Tule Lake sumps through Sheepy Ridge to the Lower Klamath Lake subbasin. Because the sumps are the ultimate collector of drain water from the Project, flow through the D Plant is a reasonable proxy for net discharge to drains in the Tule Lake subbasin.

Records of water volumes moved through the D Plant indicate decreased flow to agricultural drains on the Project since 2001 (fig. 3). Flow through the D Plant over the past decade has decreased by 61,000 acre-ft (from 81,000 acre-ft in 2000 to 20,000 acre- $f t$ in 2011). There was, however, no corresponding decrease in diversions (fig. 3), so the difference was largely due to decreased flow to drains.

\section{Sources of Water to Wells}

Surface water features such as wetlands, streams, springs, and drains are potential sources of water to wells (Barlow and Leake, 2012). As a well is pumped, most of the water initially supplied to the well is from aquifer storage. If pumping continues, a cone of depression forms in the aquifer around the well, which over time can capture groundwater that would otherwise flow to surface water features (Theis, 1940). Captured water consists of either a reduction in the natural discharge of groundwater from the aquifer to the surface features or an increase in the natural or artificial recharge rate to the aquifer (Theis, 1940; Reilly and others, 2008; Barlow and Leake, 2012). The manifestation of these effects to surface water features depends on pumping rate, duration, and the geometry and hydraulic characteristics of the aquifer being pumped.

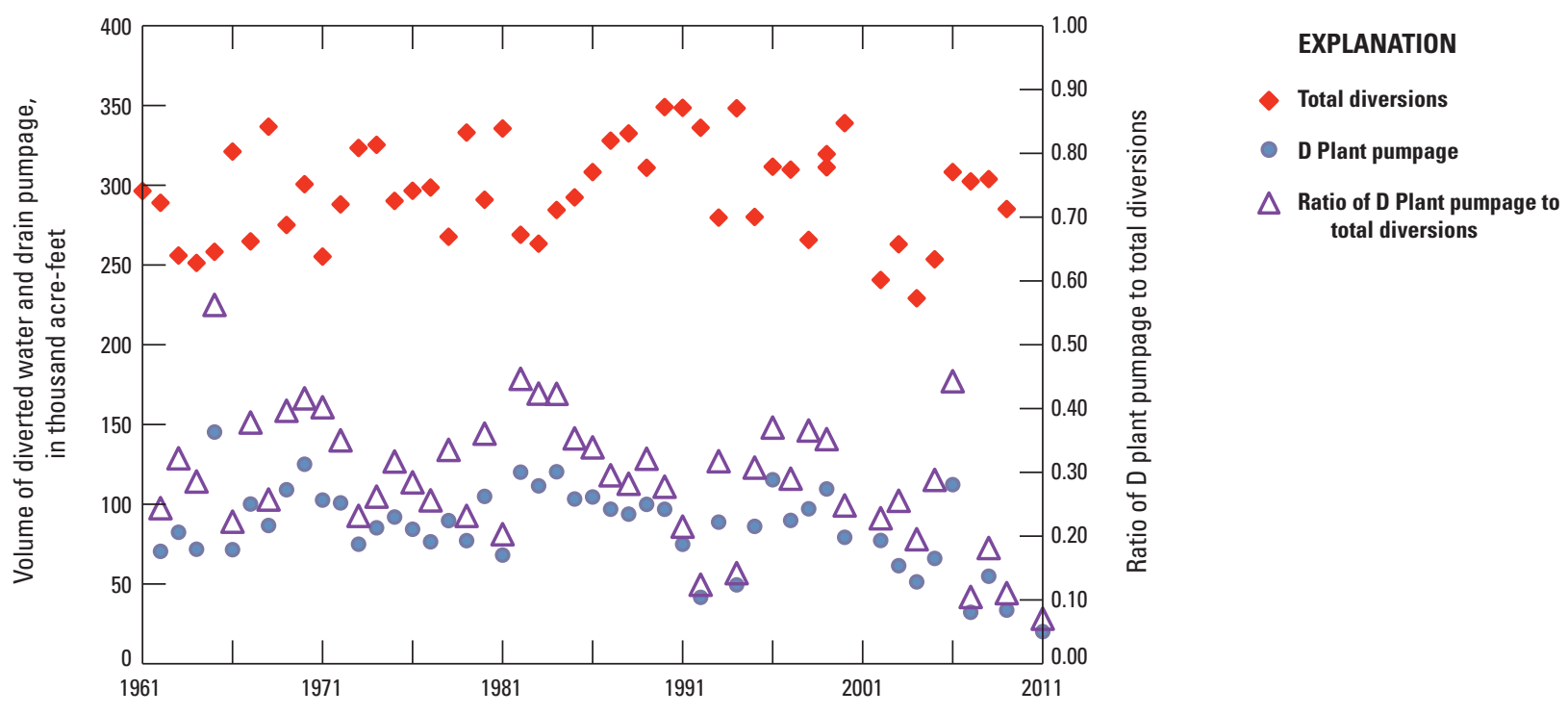

Figure 3. Total diversions (defined as the sum of March through October A Canal diversions and Lost River Diversion Channel deliveries), D Plant pumpage, and ratio of D Plant pumpage to total diversions, Tule Lake subbasin, Oregon and California, 1961-2011. Data points for 2001 and 2010 have been removed because Klamath Irrigation Project operations were severely curtailed during those years. 


\section{Changes in Hydraulic Head and Flow}

Groundwater pumping in the Project area from 2001-10 has removed groundwater from storage, resulting in water-level declines in the area's aquifers. Between 2001 and 2004, total declines of more than $10 \mathrm{ft}$ were documented in the deep volcanic aquifer over large areas of the Project, with declines exceeding $15 \mathrm{ft}$ over the northern part of the Tule
Lake subbasin (Gannett and others, 2007). Recent analysis by the Oregon Water Resources Department documents water-level declines since 2001 of 10-20 ft in areas of the Klamath Valley and northern part of the Tule Lake subbasin, with declines of 20-30 ft locally (Gall, 2011). Water-level measurements show that declines occur in all geologic units at all depths, but are largest in the deep volcanic aquifer underlying the area (fig. 4).

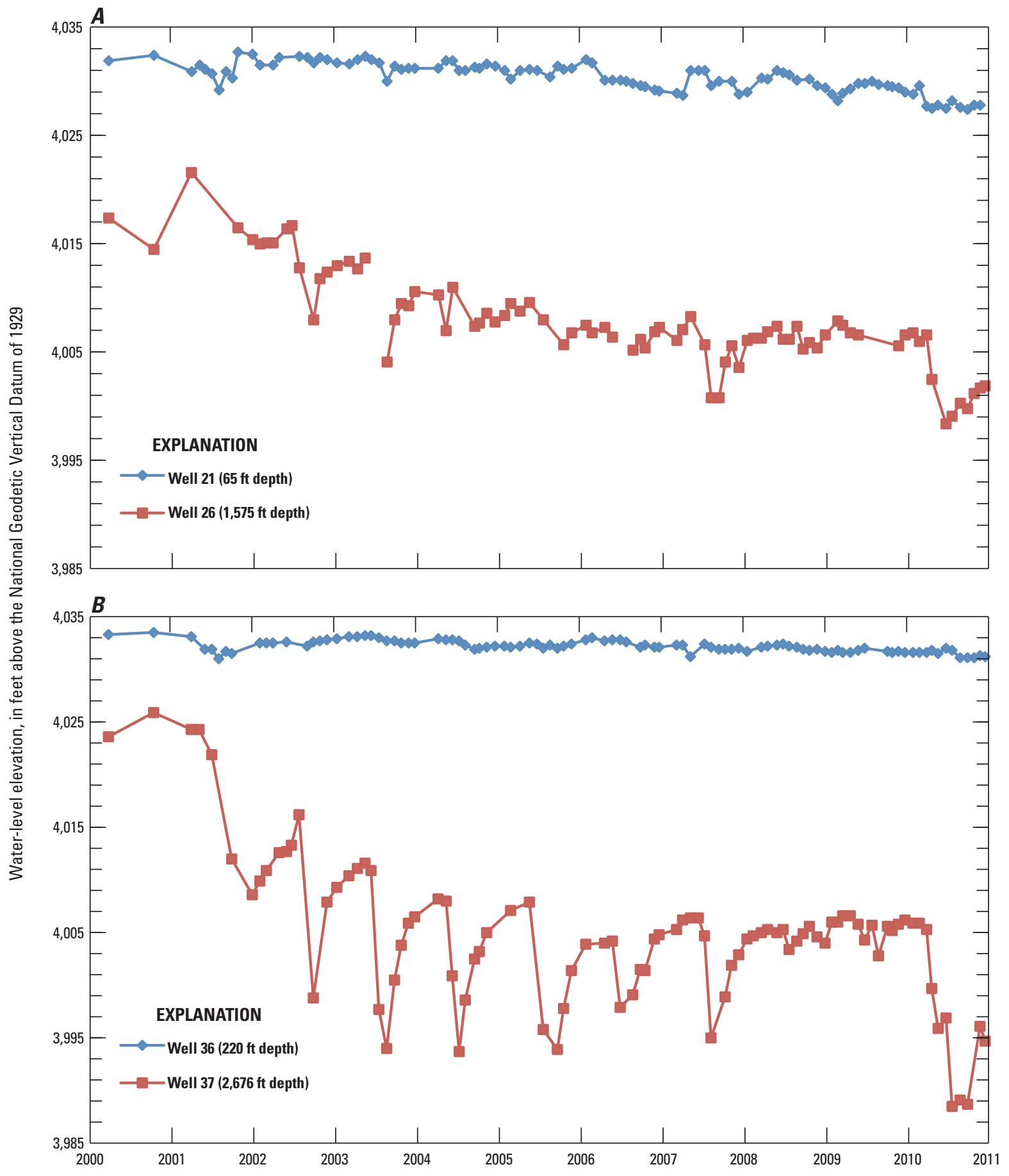

Figure 4. Four observation wells in the Tule Lake subbasin, California. Hydraulic heads declined more rapidly in deep zones than in shallow zones during the period of record (2001-11), which increased the downward vertical hydraulic gradient. Well numbers correspond to identification numbers used in the Tule Lake groundwater model. Well locations are shown in figure 10 and table 3. 
Groundwater moves from regions of high hydraulic head to low hydraulic head (Freeze and Cherry, 1979). In the Tule Lake subbasin, hydraulic heads have historically been lower in the deep volcanic aquifer than in the shallow sedimentary aquifer, indicating a component of downward vertical flow. Hydraulic heads at depth have declined faster than those in shallower wells over the past decade (fig. 4), increasing the downward hydraulic head gradient. Thus, the proportion of shallow groundwater flowing vertically to the deep aquifer rather than laterally discharging to drains has increased.

\section{Upper Klamath Basin Regional Model}

The USGS developed a groundwater-flow model for the upper Klamath Basin to simulate regional groundwater flow to help assess the resource and test management scenarios within the basin (Gannett and others, 2012). Simulations of pumping in the Tule Lake subbasin indicate that a substantial portion of the water pumped from the deep volcanic aquifer is ultimately captured from diminished discharge to drains. The model simulation results are consistent with everything known about the groundwater system, and with independent data on changes in water levels and drain discharge (as indicated by records from the D Plant).

Owing to the coarseness of the model grid, however, this USGS regional-scale flow model cannot simulate the details of the observed changes in vertical hydraulic head gradients. For example, the model cannot accurately simulate the vertical hydraulic head gradients observed within the sedimentary aquifer because the sediment is represented as a single layer in the model. Consequently, information from dozens of observation wells in the Tule Lake subbasin was not fully used for model calibration or to evaluate model accuracy.

\section{Study Objectives}

Simulations from the regional model and the marked drop in volumes of water pumped through the D Plant suggest that agricultural drains are affected by groundwater pumping. Other factors, however, could affect the D Plant volumes. Increased electrical power costs since 2000 have made it desirable to keep as much water as possible on the Tule Lake side of Sheepy Ridge. However, the ability to store, evaporate, or consumptively use this water is limited. Additionally, changes in diversion volumes, irrigation efficiency, or cropping patterns could affect drain flows (and D Plant volumes).

The goal of this investigation was to determine the magnitude of changes to drain flow in the Tule Lake subbasin and the degree to which increased groundwater pumping could be responsible for these changes. To understand the effect of increased groundwater pumping on drains, this goal has been divided into two objectives:

1. Construct a quantitative hydrologic budget of the drains to estimate changes in groundwater discharge to drains as groundwater pumping increased.

2. Develop a fine-grid groundwater model of the Tule Lake subbasin to explore the connection between groundwater and surface water in the subbasin.

\section{Methods}

\section{Drain Flow Analysis}

To evaluate the effect of increased groundwater pumping on drain flow, the change in volume pumped by the TID from drains (which reflects the change in flow to the drains from groundwater discharge and other sources) over time was analyzed. The TID manages the irrigation infrastructure, including drains, in the Oregon and California areas of the Tule Lake subbasin. TID infrastructure includes 24 pumps (fig. 5) that lift water from agricultural drains back into the water delivery system (canals and laterals) for reuse or to the Tule Lake sumps for storage and removal to Lower Klamath National Wildlife Refuge (through the D Plant). The TID maintains monthly records of the volumes pumped from these drain pumps, which are located throughout the TID system. To analyze these data, monthly time series for 1997-2012 were summed to create yearly volumes for pumps that remove water from specific areas.

\section{Drain Subareas}

When evaluating drain pump data to estimate net groundwater discharge, care must be taken to avoid double accounting of water. Drain water to be reused is pumped into a canal or lateral where it is either transported to another part of the Project or applied to land adjacent to the drain. If the water is reused in an area close to the drain, some of the water might become drain flow again. If volume from all of the drain pumps is summed for the entire irrigation district, the water that is recycled and enters the drain system again is being counted more than once. To avoid such double accounting, the irrigation districts were split into three subareas for which "terminal" pumps that discharge water outside the subarea could be identified. Yearly volumes were calculated for these terminal drain pumps and then summed to provide an estimate of total pumped volume per year for the entire irrigation district. 


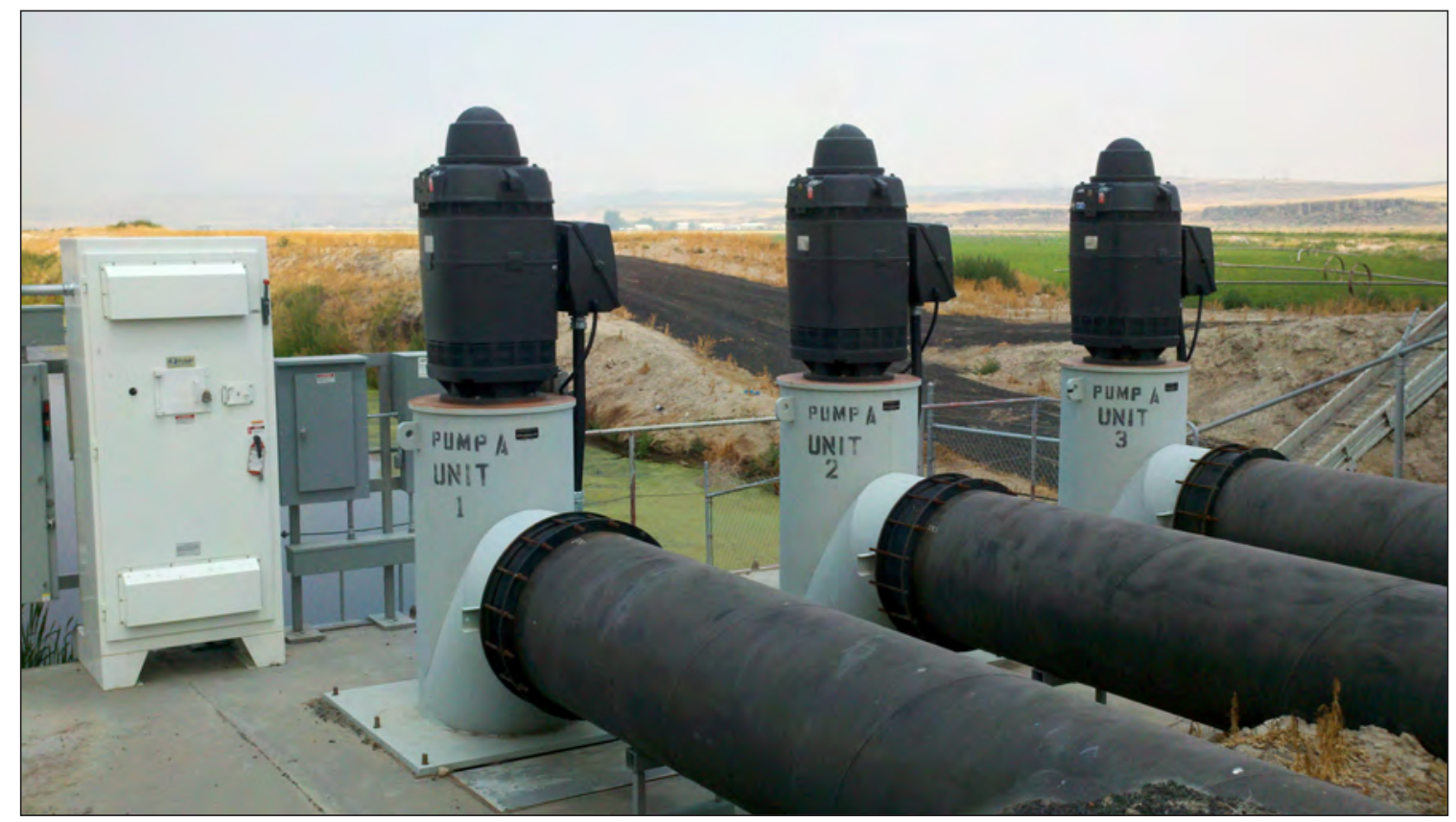

Figure 5. Example of a drain pump (pump A) in the Tulelake Irrigation District system, California. Photograph taken by Esther Pischel, U.S. Geological Survey, July 31, 2013.

\section{North Tulelake and Klamath Irrigation Districts}

North TID/KID is the largest of the subareas (fig. 6). It extends from the northern part of the Tule Lake subbasin south to the Copic Bay subarea and east to the Lease Lands subarea. Pumping from wells occurs in this subarea primarily to the north and east. The drain pumps that integrate this area are $3,4,5,6,12,27$, and A. These pumps move drain water into major canals that supply water to other subareas; little or none of this water is reused in the North TID subarea.

\section{Copic Bay}

Copic Bay is in the southeastern corner of the study area (fig. 6). Groundwater pumping takes place throughout this subarea. Pump B is located at the end of the Copic Bay system and integrates most of the drain flow. Pump B discharges into Sump 1B, and the water is not recycled in the Copic Bay subarea.

\section{Lease Lands}

Tule Lake National Wildlife Refuge contains 17,000 acres of Federal land that is leased to farmers. These lands are referred to as the "Lease Lands" (fig. 6). The Lease Lands are located directly south and east of Sump 1A and north of Sump 1B, and include the lowest elevation areas in the subbasin. The pumps that integrate this region are pumps $9,10,10 \mathrm{~A}, 11$, and $\mathrm{C}$, which pump directly into Sumps 1A and $1 \mathrm{~B}$. The water pumped from the drains into the sumps is not reused in the subarea, reducing the chance that drain water will be double accounted. Unlike the North TID/KID and Copic Bay subareas, little to no groundwater pumping takes place in the Lease Lands.

\section{Operational Spills}

To evaluate the changes that have taken place in drain flow because of changes in the groundwater system, the component of the drain flow that is from operational spill by the KID must be subtracted because changes in surface-water deliveries to drains could mask changes occurring in the groundwater component of flow. Although the operational spill volumes recorded by the KID are not precise, they are the best information available to understand the magnitude of spills to TID drains. Backspill from canals to maintain water levels in drains for pumps to work effectively is another quantifiable source of additional water to drains. This occurs at pump A, one drain pump used in this analysis. Annual volumes of water spilled to the drain near pump A were subtracted from the total drain pumpage. Operational spill from KID and TID backspills are two sources of drain inflow that can be reasonably estimated. Some potential sources of surface water to drains, such as direct runoff from fields (overland flow), cannot be as easily quantified and are assumed to have remained constant during the period analyzed. 


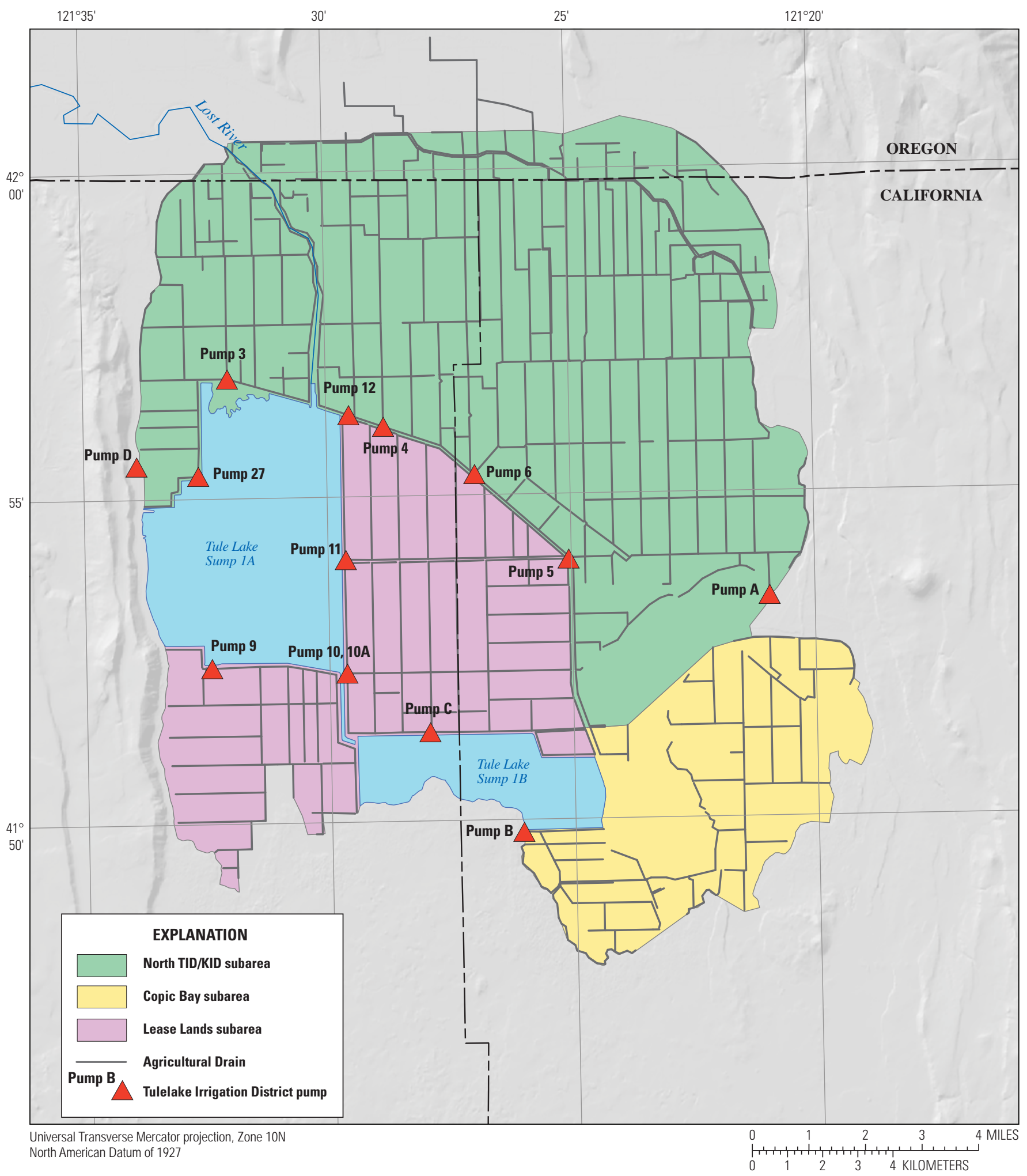

Figure 6. Subareas and drain pumps used in analysis of drain flow, Tule Lake subbasin, Oregon and California. Although not included in the analysis of drain flow, the D Plant is included here for reference. 


\section{Other Possible Causes of Decreased Drain Flow}

Factors other than groundwater pumping could contribute to decreases in drain flow, including reductions in surface-water diversions, increased irrigation efficiency, or reductions in acreage farmed in the subbasin. Total annual diversion volumes (defined as the sum of March-October A-Canal diversions and Lost River Diversion Channel deliveries), although variable, did not change systematically between 2000 and 2010, whereas D Plant pumpage decreased (fig. 3). Moreover, the ratio of D Plant volumes to total annual diversions decreased in a manner similar to the D Plant volumes, indicating that increasingly smaller proportions of diverted water end up at the D Plant (fig. 3).

Irrigation efficiency has not increased significantly from at least 2001 through 2012 in the Tule Lake subbasin. In the TID, which covers most of the Tule Lake subbasin, the main types of irrigation are solid-set sprinkler and wheel-line irrigation. About 18 percent of the acreage in the TID is flood irrigated. These irrigation methods have, for the most part, remained constant (Brad Kirby, Tulelake Irrigation District, oral commun., 2014).

Likewise, the acreage farmed has not changed significantly from 2001 through 2012 (Brad Kirby, Tulelake Irrigation District, oral commun., 2014). Cropping patterns have remained steady since 2002. Major crops grown in the Tule Lake subbasin are alfalfa, grains such as barley and wheat, potatoes, onions, and mint.

\section{Groundwater Model}

A smaller-scale, fine-grid groundwater model based on the larger-scale regional groundwater model (Gannett and others, 2012) was constructed, integrating hydrologic and geologic data for the subbasin. To be consistent with the regional model and to take advantage of its parameter estimation capabilities (Hill and others, 2000), the Tule Lake groundwater model uses the USGS MODFLOW 2000 modeling code (Harbaugh and others, 2000). Subbasin geometry and starting values for certain model parameters were used from the regional model. The model was calibrated to water level time series from 24 wells in the study area using trial-and-error and inverse methods. The calibration was also constrained by observed changes in drain flows and independent estimates of recharge.

\section{Discretization}

To address the limitations of the regional model and more accurately simulate pumping and water levels, the Tule Lake subbasin was discretized at a finer scale in the horizontal and vertical dimensions. Finer discretization allows for finer resolution of drains, vertical hydraulic head gradients, and hydrogeologic zonation to better determine effects on drain flows from increased groundwater pumping.
Model cells in the Tule Lake groundwater model have a lateral dimension of 1,250 by 1,250 ft (one-fourth the area of cells in the regional model), which captures the resolution of important features such as drains while limiting the number of model cells for computational efficiency. The model domain is 84 rows north to south, 67 columns east to west (fig. 7), and 12 layers, for a total of 67,536 model cells. All layers are modeled as confined, and layer thicknesses range from 25 to $700 \mathrm{ft}$ (table 1). For transient models, time is discretized using stress periods and time steps. The Tule Lake groundwater model has been constructed to simulate quarterly stress periods for water years $2000-10$, preceded by a single steady-state stress period (a water year begins on October 1 and ends on September 30; for example, the 2000 water year started October 1, 1999 and ended September 30, 2000.) The steady state stress period simulates initial conditions for the transient simulation.

\section{Hydrogeologic Zonation}

The zonation of the model (fig. 8) is based on the hydrogeology of the upper Klamath Basin presented in Gannett and others (2007) and is specified in the model using the Layer Property Flow package (figs. 8 and 9). The youngest hydrogeologic units in the subbasin represented in the model are Quaternary sediments (Qs) and Quaternary volcanics (Qv). The Quaternary sediments are the topmost part of the basin-fill sediment and are modeled in layer 1. Quaternary volcanics are present in the southernmost part of the model and were determined to be about $150 \mathrm{ft}$ thick, based on drillers' logs; they extend from layer 1 to layer 4 . Tertiary sediments of younger basins (Tsy) compose the remainder of the basin-fill sediment and are in layers 2-11. Underlying the basin-fill sediment and cropping out on the fringes of the subbasin are Tertiary sediments and volcanic rocks (Tsv). Tsv is present in all 12 layers. Faulting occurs in the subbasin, related predominantly to Basin and Range extension. These faults are on the west and east boundaries of the subbasin.

Table 1. Layer thicknesses for the Tule Lake groundwater model.

[Hydrogeologic units represented: Qs, Quaternary sediments; Qv, Quaternary volcanics; Tsv, Tertiary sediments and volcanics; Tsy, Tertiary sediments of younger basins]

\begin{tabular}{ccl}
\hline Layer & $\begin{array}{c}\text { Thickness } \\
\text { (feet) }\end{array}$ & $\begin{array}{c}\text { Hydrogeologic units } \\
\text { represented }\end{array}$ \\
\hline 1 & 25 & Qs, Qv, Tsv \\
2 & 25 & Qv, Tsv, Tsy \\
3 & 50 & Qv, Tsv, Tsy \\
4 & 50 & Qv, Tsv, Tsy \\
5 & 50 & Tsv, Tsy \\
6 & 100 & Tsv, Tsy \\
7 & 200 & Tsv, Tsy \\
8 & 200 & Tsv, Tsy \\
9 & 300 & Tsv, Tsy \\
10 & 400 & Tsv, Tsy \\
11 & 500 & Tsv, Tsy \\
12 & 700 & Tsv \\
\hline
\end{tabular}


$121^{\circ} 40^{\prime}$

35

$30^{\prime}$

$25^{\prime}$

$121^{\circ} 20^{\prime}$

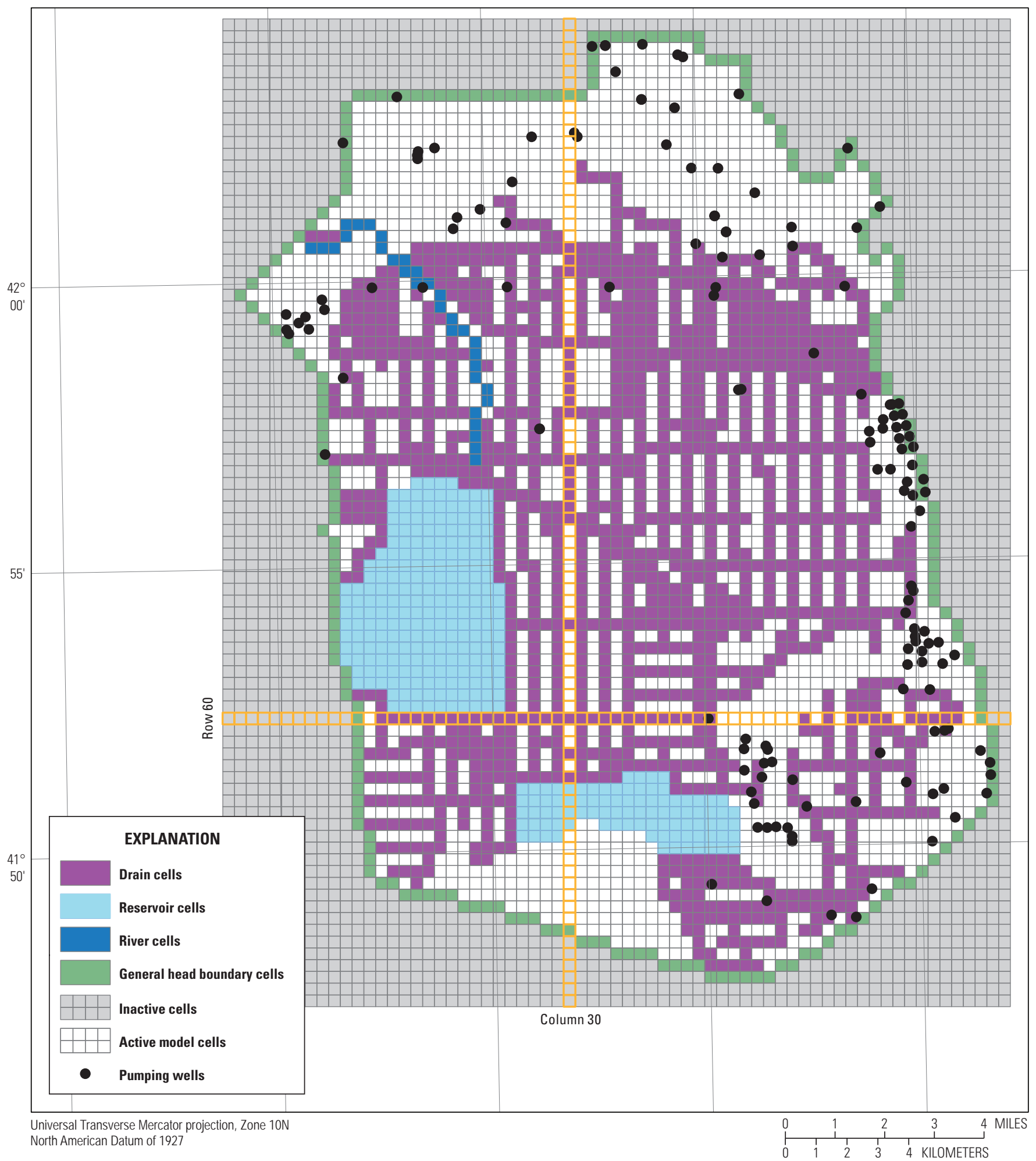

Figure 7. Groundwater-model grid and boundary conditions, Tule Lake subbasin, Oregon and California. Highlighted column 30 and row 60 correspond to sections shown in figure 9. 


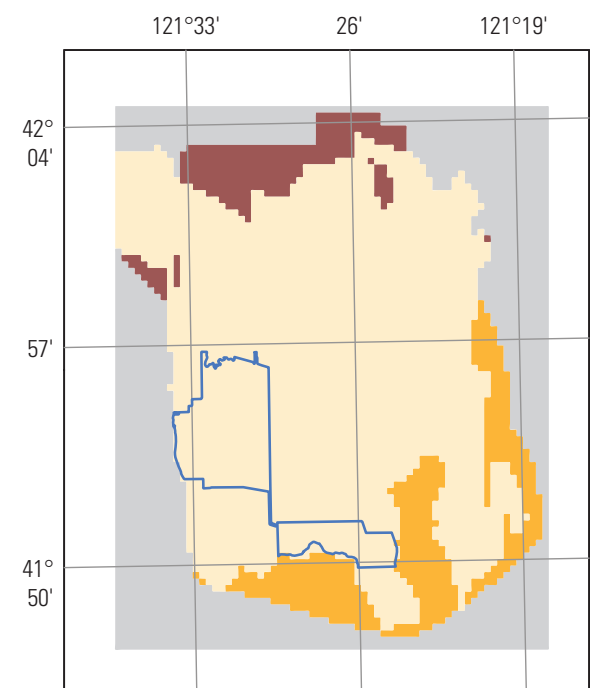

Layer 1, 0-25 feet

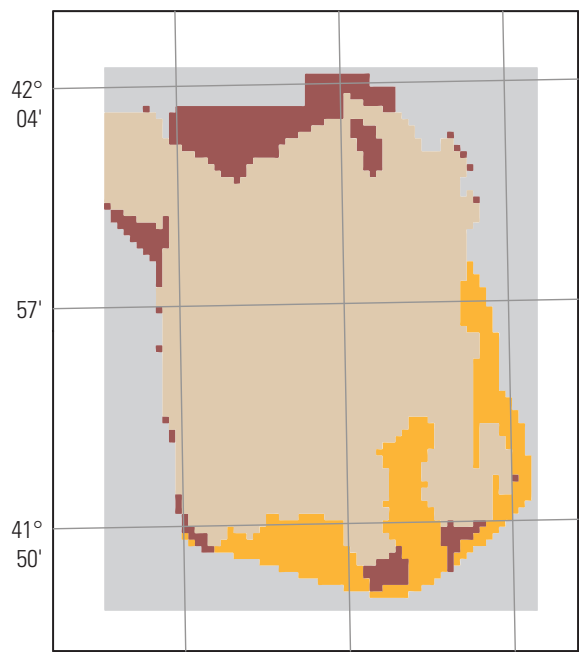

Layer 4, 100-150 feet

Universal Transverse Mercator projection, Zone 10N North American Datum of 1927

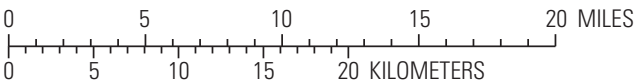

\section{EXPLANATION}

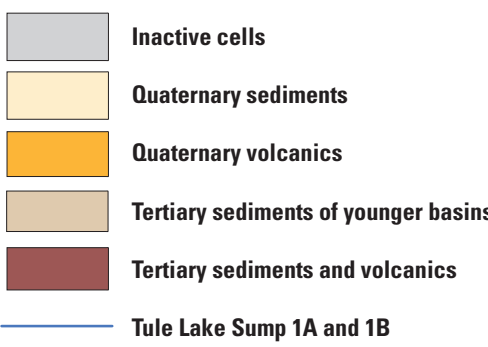

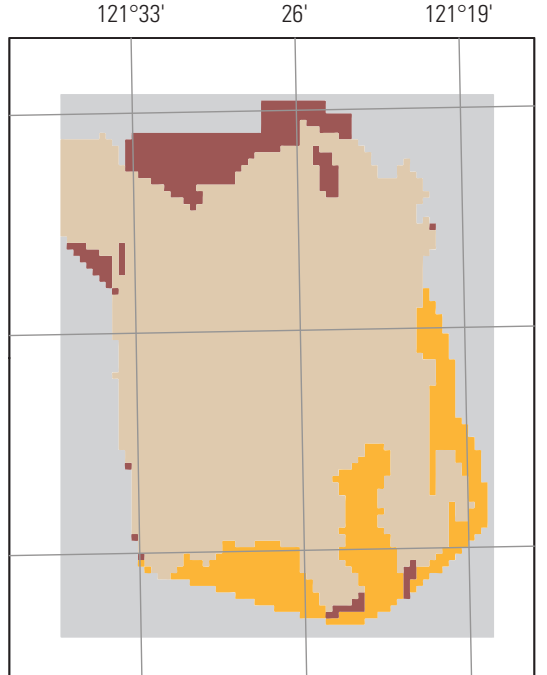

Layer 2, 25-50 feet

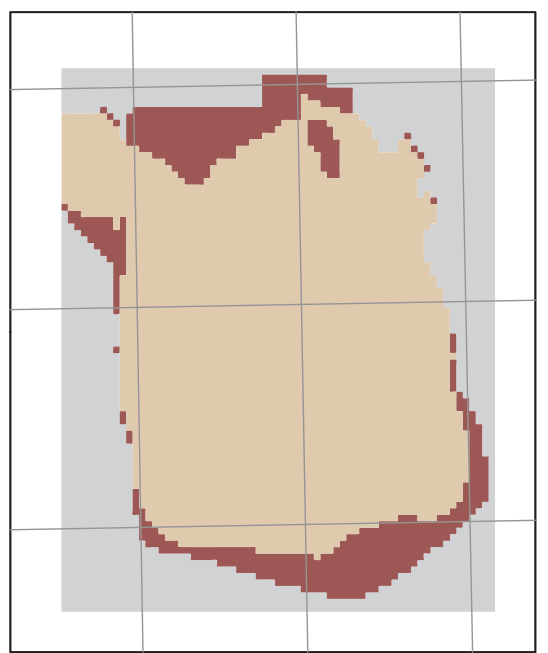

Layer 5, 150-200 feet

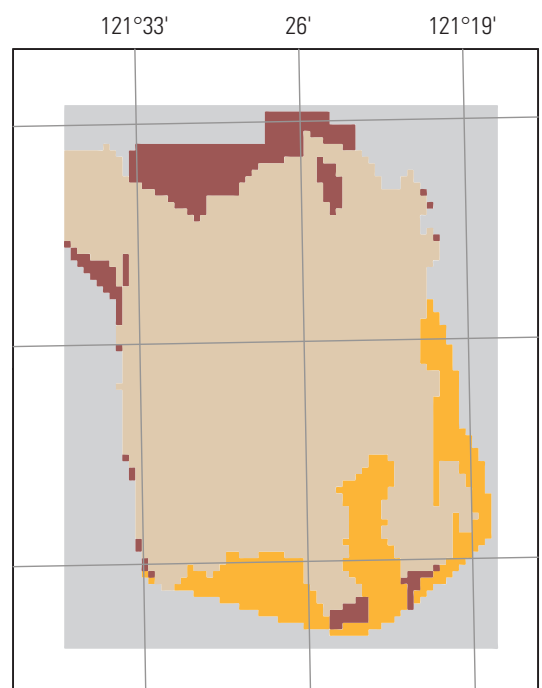

Layer 3, 50-100 feet

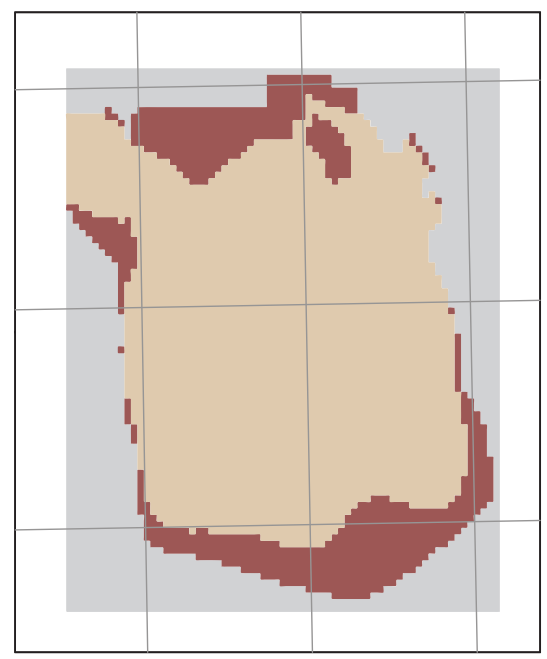

Layer 6, 200-300 feet

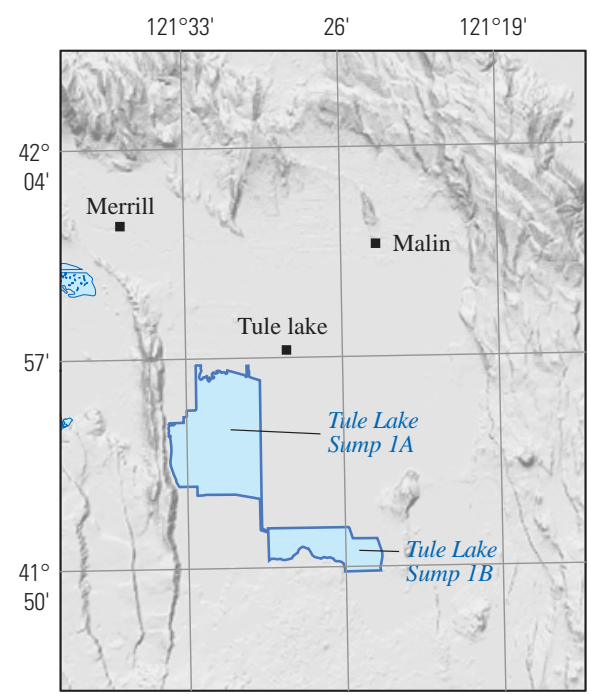

Figure 8. Hydrogeologic zonation of the Tule Lake groundwater model, Tule Lake subbasin, Oregon and California. The Tule Lake sumps, shown in the index map, are shown in the first layer as a spatial reference. Depth interval follows each layer number. 


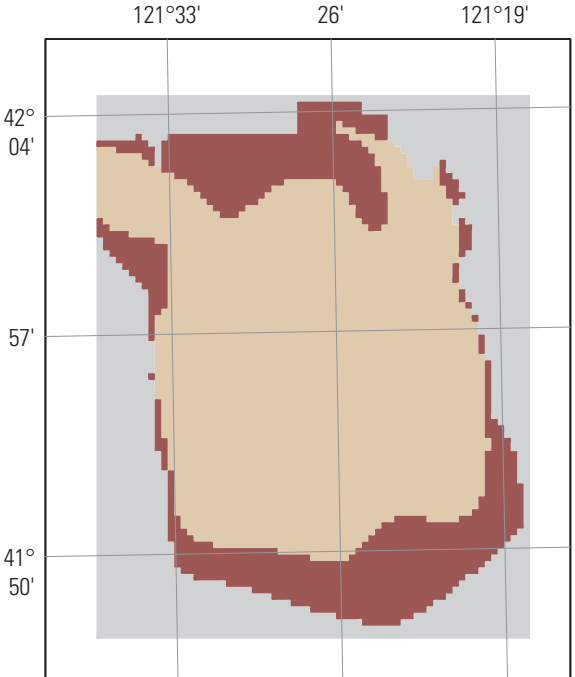

Layer 7, 300-500 feet

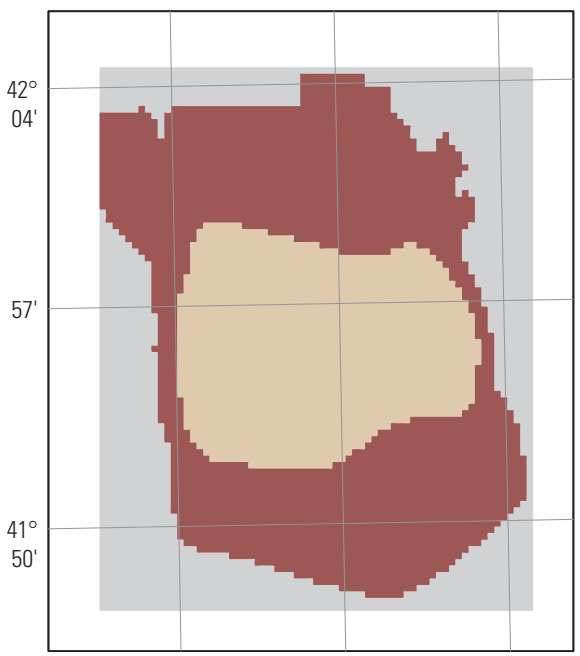

Layer 10, 1,000-1,400 feet

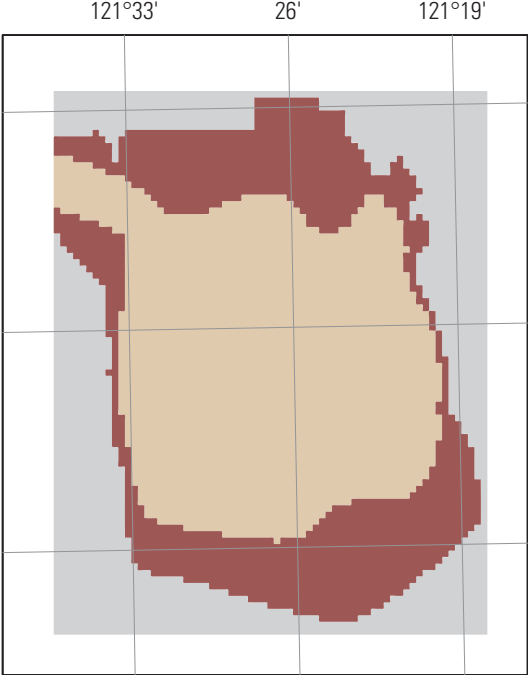

Layer 8, 500-700 feet

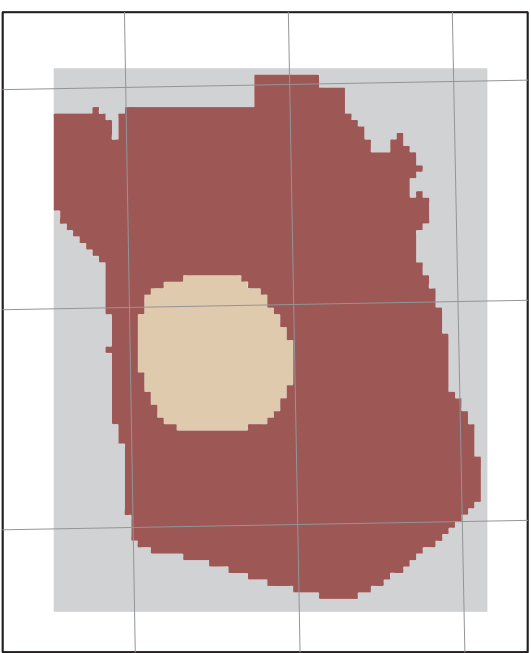

Layer 11, 1,400-1,900 feet

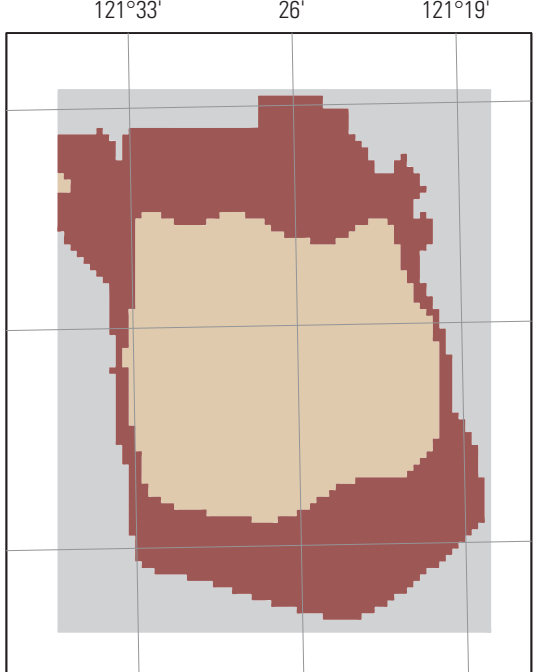

Layer 9, 700-1,000 feet

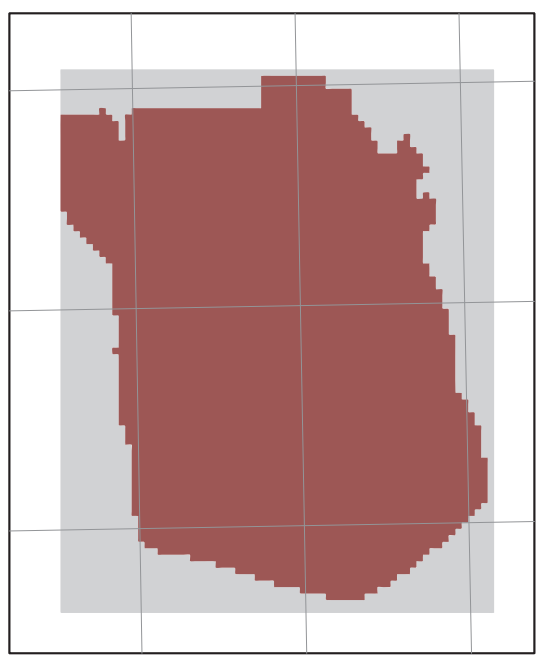

Layer $12, \quad 1,900-2,600$ feet

Universal Transverse Mercator projection, Zone 10N North American Datum of 1927

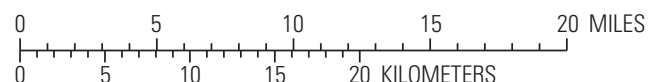

\section{EXPLANATION}

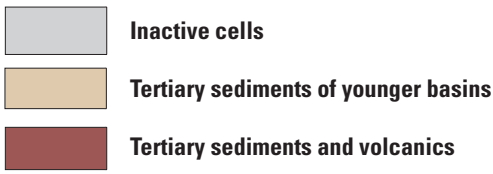

Figure 8.-Continued 


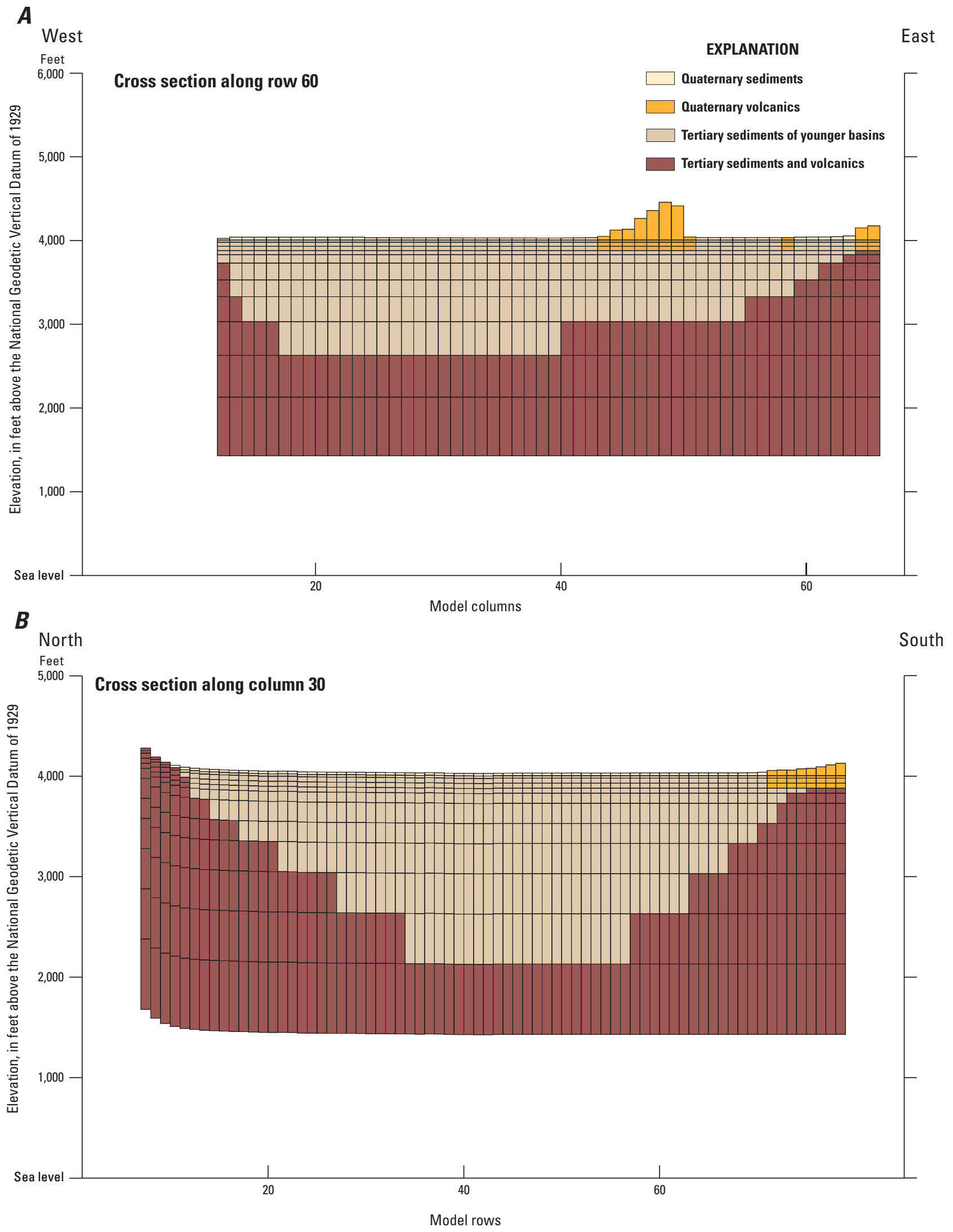

Figure 9. Tule Lake groundwater model, Tule Lake subbasin, Oregon and California. ( $A$ ) Section west to east along model row 60 , and $(B)$ section north to south along model column 30 . Row and column locations are shown in figure 7. 


\section{Boundary Conditions}

Boundary conditions determine the way in which water is allowed to move into or out of the groundwater model. Boundary conditions for the Tule Lake groundwater model are shown in figure 7.

\section{Specified Flow Boundaries}

Specified flow boundaries are those across which groundwater flows into or out of the model at specified rates. These specified rates can vary in time and space. Specified flow boundaries in this model are areally distributed recharge and pumping wells.

\section{Recharge}

Recharge is water that infiltrates to the water table and becomes groundwater (Anderson and Woessner, 1992). The primary source of recharge in the Tule Lake subbasin is infiltration of applied irrigation water and canal leakage. Precipitation is also a source of recharge but is comparatively small. The volume of recharge from precipitation was estimated using the Precipitation-Runoff Modeling System and was taken directly from the upper Klamath Basin regional model (Gannett and others, 2012). Recharge rates from water year 1980 (which are close to the long-term average [Gannett and others, 2012]) were varied on a seasonal basis and repeated during the simulation to simplify model analysis.

Recharge from infiltration of irrigation water and canal leakage was estimated for the regional model by Gannett and others (2012) using a water balance calculated for the Project by the Irrigation Training and Research Center (Burt and Freeman, Irrigation Training and Research Center, unpub. data, 2003). A value of $1 \mathrm{ft} / \mathrm{yr}$ was applied to the Project area. Gannett and others (2012) detail the calculation of recharge volumes for the regional model. Because simulated net recharge accounts for ET, it is not explicitly simulated in the model. Throughout this report, net recharge is referred to simply as recharge.

Given that irrigation canal leakage is a predominant source of recharge in the Tule Lake subbasin, refinements to recharge were made in the Tule Lake subbasin model based on two factors relating to irrigation: (1) relatively low density of canals in the northern part of the study area and (2) curtailed Project diversions in the dry years 2001 and 2010. The low density of canals in the northern part of the study area means that less recharge can be expected due to canal leakage. Adjusting recharge to reflect the lower density of canals resulted in more accurate simulation of water-levels in that area. The final value of recharge in the northern part of the study area, assuming constant ET and irrigation efficiency, was approximately $0.25 \mathrm{ft} / \mathrm{yr}$.
The other refinement of recharge in the Tule Lake model was related to curtailed irrigation diversions in 2001 and 2010. In all years except 2001 and 2010, a $1.0 \mathrm{ft} / \mathrm{yr}$ recharge rate was used. The Project received considerably less surface water for irrigation during the dry years of 2001 and 2010, and artificial recharge from deep percolation of applied irrigation water and canal leakage was likely reduced in the same proportion as the reduced diversions. To account for decreased diversions, recharge was scaled back throughout the model domain to 32 percent in 2001 and 55 percent in 2010 to match the scaling-back of irrigation diversions those years.

\section{Groundwater Pumping}

Groundwater pumped from wells also is represented as a specified-flow boundary. Groundwater pumping is commonly divided into two categories: primary and supplemental. Primary pumping is water pumped to irrigate land where groundwater is the sole source of water. Supplemental pumping is water pumped to irrigate land normally irrigated by surface water during times when surface water is not available, such as drought. Most of the supplemental pumping in the Tule Lake subbasin over the past decade has been part of government-sponsored efforts. A smaller (but generally less well quantified) amount of supplemental pumping occurs privately. For this study, primary pumping and private supplemental pumping is referred to as "background pumping," and the term "supplemental pumping” is reserved hereafter for pumping done under government-sponsored programs.

Background pumping rates are based on surveys of crop type and irrigation methods, analysis of satellite imagery, water rights information, and flowmeter readings, and are derived from the work of Gall (2011) and Gannett and others (2007). In the Tule Lake subbasin, background pumping (which includes primary and private-supplemental pumping) averages about 7,970 acre-ft/yr.

Supplemental pumping rates are based on information from the Bureau of Reclamation, Oregon Water Resources Department (OWRD), and the Klamath Water and Power Authority (KWAPA). Supplemental pumping in the model averages 23,500 acre-ft/yr. The pumping data were provided in differing formats depending on the year and the agency. For 2001-04, the pumping data were provided as an annual total for individual wells or groups of wells. For 2005-07, the data were provided as the aggregate total of pumping for all supplemental wells. The quarterly pumping volume used in the model for each well in 2005-07 was calculated in proportion to the relative pumping volumes in 2004 (2004 data were provided for single wells or well groups). No supplemental pumping was reported for 2008 and 2009, and for 2010, data were provided well by well by OWRD and KWAPA. 
Effects of Groundwater Pumping on Agricultural Drains, Tule Lake Subbasin, Oregon and California

Some values for supplemental pumping were modified from reported values to adjust for possible under- or overestimation of pumping rates. For example, although there was no stated Project-sponsored pumping in 2008 and 2009, hydrograph data during those years show some effects greater than what would be expected solely from estimated background pumping. To account for this in the model, supplemental pumping rates in 2008 and 2009 were adjusted until simulated pumping resulted in observed drawdowns. Additionally, supplemental pumping rates in 2001-04 were adjusted to reflect new information on actual pumping capacities of wells and to better match observed drawdowns in hydrograph data.

The average rate of pumping is defined for each stress period in cells that contain a pumping well. Pumping data were most commonly provided as annual totals, so the exact timing of pumping is poorly known. Moreover, some data were provided as total pumped-water volumes for groups of wells, or all wells for a particular year. This uncertainty in the exact location and timing of pumping limited the ability to precisely match observed water table fluctuations. Wells are assigned to single layers based on the open interval of the wells and water-bearing zones described by drillers.

\section{Head-Dependent Flow Boundaries}

Head-dependent flow boundaries in the model include the Lost River, Tule Lake sumps, drains, and interbasin groundwater flow. The rate of groundwater flow to or from these features is controlled by the difference between the hydraulic head in the cell and the hydraulic head of the feature (such as the stage of the river, sump, or drain).

\section{Lost River}

The Lost River is the only river in the study area, and is modeled using MODFLOW's river (RIV) package (McDonald and Harbaugh, 1988). The RIV package was used instead of a more sophisticated package such as the streamflow routing (SFR) package because it met the needs of the study. The spatial extent of the river within the model domain was determined using digital geographic information system (GIS) data, and river width and stage were determined using 1:24,000 USGS topographic maps. Water from a RIV boundary can move to or from the groundwater system, depending on the hydraulic head difference between the river and the cell in which it is simulated. The rate of flow is proportional to the riverbed conductance. The initial riverbed conductance was calculated based on estimates of aquifer properties from the regional model and then adjusted during calibration.

\section{Tule Lake Sumps}

The Tule Lake sumps are simulated as reservoirs in the model because they are artificially controlled. As such, MODFLOW's reservoir (RES) package was used. The spatial extent of each sump was determined using a USGS 1:24,000 topographic map. Stage measurements of the Tule Lake sumps were not available during the simulation period, so the water level in each sump was fixed at a long-term average value of 4,033 ft (Gannett and others, 2007). Water moves to or from the sumps in proportion to the hydraulic head difference between the sumps and the cells in which they are modeled and the conductance of the reservoir bottom. The initial RES conductance was calculated based on estimates of aquifer properties from the regional model and then adjusted during calibration.

\section{Drains}

Agricultural drains are modeled using MODFLOW's drain (DRN) package. The spatial distribution of drains in the study area was delineated using GIS data provided by the Bureau of Reclamation. The drain elevation in MODFLOW was set to $10 \mathrm{ft}$ below land surface based on field observations and the regional model calibration, and the drain width was set to a constant $10 \mathrm{ft}$. Like other head-dependent flow boundaries, the flow of water to the drain is dependent on the hydraulic head difference between the drain and the cell in which it is modeled and the conductance of the drain bottom. Unlike other head-dependent flow boundaries, flow in drain cells is unidirectional; that is, flow can occur only from the groundwater system to the drain (as opposed to a river cell, for example, in which flow can move from the groundwater system to the river or from the river to the groundwater system). This is because drains are designed to provide an outlet for shallow groundwater to be carried away and do not function as a source of groundwater to the aquifer like a river. The initial drain conductance was calculated based on estimates of aquifer properties from the regional model and then adjusted during calibration.

\section{Interbasin Groundwater Flow}

Interbasin groundwater flow represents horizontal flow across the model domain boundaries. Interbasin groundwater flow from the Tule Lake subbasin southward toward the Pit River Basin (fig. 1) is discussed in Gannett and others (2007). Additionally, interbasin flow is expected across other model boundaries because the permeable Tertiary volcanics and basin-filling sediment in the subbasin extend beneath the fault-block ridges that separate the Tule Lake subbasin from the Poe Valley to the north, the Clear Lake subbasin 
to the east, and the Lower Klamath Lake subbasin to the west, allowing groundwater to flow between these areas (fig. 1). Flow to and from adjacent areas was simulated using MODFLOW's general head boundary (GHB) package. GHB cells, therefore, are located around the edge of the model domain.

General head boundaries are similar to river or reservoir boundaries in that flow to or from the model is controlled by hydraulic head relations between the model cells and an external source or sink. Head values adjacent to the model were derived from hydraulic head contours from Gannett and others (2007). The initial GHB conductance was calculated by using estimates of aquifer properties from the regional model then adjusted during model calibration. A list of MODFLOW packages used in this model is shown in table 2.

\section{Model Calibration}

Calibration is a process in which model structure and parameters are adjusted to achieve the best fit between simulated and observed values of hydraulic heads and flows. The observed, or measured, values used to calibrate the Tule Lake model included spring (March, or sometimes March and April) water-level measurements from 24 observation wells located throughout the subbasin (fig. 10, table 3). Spring water levels were used to minimize error due to drawdown during pumping. Although there are 42 observation wells in the modeled area, 18 were not used because the water levels contained anomalous values caused by stresses not simulated in the model, such as localized canal influence and nearby groundwater pumping. The changes in summed drain pumpage from the three Tule Lake subareas (fig. 6) used in the drain flow analysis were also used to constrain calibration. The model was calibrated using both trial-and-error and parameter estimation methods. The trial-and-error method involves iteratively adjusting model structure and model parameters (such as hydraulic conductivity) to achieve an acceptable match between simulated and observed hydraulic head values. Parameter estimation is an automated process in which non-linear regression is used to determine parameter values that provide the best overall fit between observations and simulated values. In total, there are 21 parameters. Sixteen of these parameters were estimated using parameter estimation. The remaining parameters were determined using trial-and-error calibration. Parameters in the model include hydraulic conductivity (HK), vertical anisotropy (VANI), and specific storage (SS) for the four geology types present in the model; the recharge multiplier, which can be used to scale recharge up and down; and the conductance of the general head boundaries, drain bed, and river bed. The model simulates the hydrogeologic system as entirely confined, so specific yields are not part of the parameter set; rather, specific storage is included for each geology type in the model.
Table 2. MODFLOW-2000 packages and files used in the Tule Lake subbasin model.

MODFLOW-2000 processes, packages, and files

Basic (BAS) Package
Output Control (OC) Option file
Discretization (DIS) file
Layer Property Flow (LPF) Package
Multiplier (MULT) file
Zone (ZONE) file
Preconditioned Conjugate-Gradient (PCG) Solver Package
Observation (OBS) Process
Sensitivity (SEN) Process
Parameter-Estimation (PES) Process
Head-Observation (HOB) Package
Drain (DRN) Package
River (RIV) Package
Reservoir (RES) Package
General Head Boundary (GHB) Package
Recharge (RCH) Package
Well (WEL) Package

The specific storage of the Tsy and Tsv are each split into two parameters, one for the upper section (layers 2-4 for Tsy and layers 1-4 for Tsv) and one for the lower section (layers 5-11 for Tsy and layers 5-12 for Tsv). This allowed flexibility in estimating the specific storage for geology types that span multiple model layers.

The parameter estimation process of MODFLOW 2000 uses a weighted least-squares objective function, $\mathrm{S}(\mathrm{b})$, to quantitatively compare observed and simulated values:

$$
S(b)=\sum_{i=1}^{N} \omega_{i}\left[y_{i}-y_{i}^{\prime}(b)\right]^{2}
$$

where

b is a vector containing values of each of the parameters being estimated,

$\mathrm{N}$ is the number of observations,

$y_{i}$ is the ith observation being matched by the regression,

$\mathrm{y}_{\mathrm{i}}^{\prime}(\mathrm{b}) \quad$ is the simulated value which corresponds to the ith observation (a function of b), and

$\omega_{\mathrm{i}} \quad$ is the weight for the ith observation (Hill, 1998).

Only hydraulic heads were used for parameter estimation. Weights for hydraulic-head measurements were based on measurement error. Because most well elevations were surveyed and all observations are springtime measurements, weights were based on an assumed standard deviation of $1 \mathrm{ft}$. The regression process calculates the set of parameter values that minimize the objective function, providing the best fit given a particular model (Hill, 1998). 


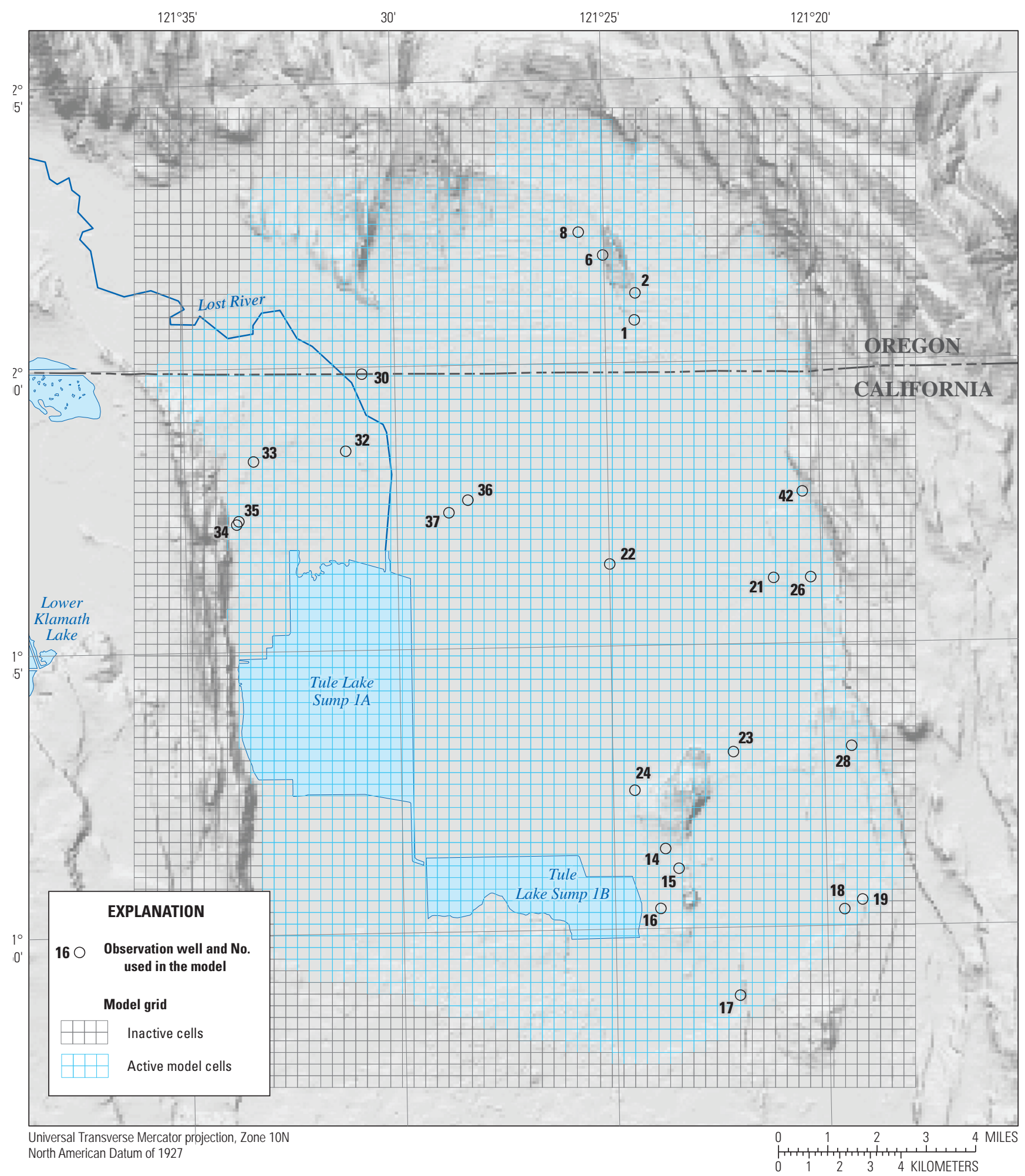

Figure 10. Locations of observation wells for the Tule Lake subbasin model, Oregon and California. 
Table 3. Model observation wells.

[CASGEM, California Statewide Groundwater Elevation Monitoring; NWIS, National Water Information System; -, not applicable]

\begin{tabular}{|c|c|c|c|c|c|c|}
\hline $\begin{array}{c}\text { Model } \\
\text { well No. }\end{array}$ & State & Location & $\begin{array}{l}\text { NWIS site } \\
\text { identifier }\end{array}$ & $\begin{array}{c}\text { State } \\
\text { well No. }\end{array}$ & $\begin{array}{c}\text { CASGEM } \\
\text { station } \\
\text { identifier }\end{array}$ & $\begin{array}{l}\text { CASGEM } \\
\text { well No. }\end{array}$ \\
\hline 2 & Oregon & $41.00 \mathrm{~S} / 12.00 \mathrm{E}-10 \mathrm{CCC} 01$ & 420116121241801 & KLAM 11254 & - & - \\
\hline 6 & Oregon & 41.00S/12.00E-09BAD01 & 420154121250301 & KLAM 51611 & - & - \\
\hline 8 & Oregon & $41.00 \mathrm{~S} / 12.00 \mathrm{E}-04 \mathrm{CBC} 01$ & 420220121253701 & KLAM 10462 & - & - \\
\hline 16 & California & $46.00 \mathrm{~N} / 05.00 \mathrm{E}-09 \mathrm{~J} 02 \mathrm{M}$ & - & 46N05E09J002M & - & $418393 \mathrm{~N} 1214003 \mathrm{~W} 001$ \\
\hline 17 & California & $46.00 \mathrm{~N} / 05.00 \mathrm{E}-23 \mathrm{G} 02 \mathrm{M}$ & - & 46N05E23G002M & 36891 & 418133N1213697W001 \\
\hline 18 & California & $46.00 \mathrm{~N} / 06.00 \mathrm{E}-07 \mathrm{~K} 02 \mathrm{M}$ & - & 46N06E07K002M & 24092 & $418385 \mathrm{~N} 1213278 \mathrm{~W} 001$ \\
\hline 19 & California & $46.00 \mathrm{~N} / 06.00 \mathrm{E}-08 \mathrm{E} 01 \mathrm{M}$ & - & 46N06E08E001M & 24093 & 418410N1213207W001 \\
\hline 21 & California & $47.00 \mathrm{~N} / 05.00 \mathrm{E}-01 \mathrm{~N} 01 \mathrm{M}$ & - & 47N05E01N001M & 37478 & 419361N1213534W001 \\
\hline 28 & California & $47.00 \mathrm{~N} / 06.00 \mathrm{E}-30 \mathrm{H} 01 \mathrm{M}$ & - & 47N06E30H001M & 23459 & 418863N1213240W001 \\
\hline 30 & California & $48.00 \mathrm{~N} / 04.00 \mathrm{E}-16 \mathrm{~L} 02 \mathrm{M}$ & - & 48N04E16L002M & 23471 & 419980N1215138W001 \\
\hline 32 & California & $48.00 \mathrm{~N} / 04.00 \mathrm{E}-28 \mathrm{D} 01 \mathrm{M}$ & - & 48N04E28D001M & 23472 & 419756N1215209W001 \\
\hline 33 & California & $48.00 \mathrm{~N} / 04.00 \mathrm{E}-30 \mathrm{~F} 01 \mathrm{M}$ & - & 48N04E30F001M & 23473 & $419726 \mathrm{~N} 1215574 \mathrm{~W} 001$ \\
\hline 34 & California & $48.00 \mathrm{~N} / 04.00 \mathrm{E}-31 \mathrm{M} 01 \mathrm{M}$ & - & 48N04E31M001M & 37484 & $419542 \mathrm{~N} 1215655 \mathrm{~W} 001$ \\
\hline 35 & California & $48.00 \mathrm{~N} / 04.00 \mathrm{E}-31 \mathrm{~N} 02 \mathrm{M}$ & - & 48N04E31N002M & 23474 & 419534N1215666W001 \\
\hline 36 & California & $48.00 \mathrm{~N} / 04.00 \mathrm{E}-35 \mathrm{G} 01 \mathrm{M}$ & - & 48N04E35G001M & 37485 & $419608 \mathrm{~N} 1214731 \mathrm{~W} 001$ \\
\hline 37 & California & $48.00 \mathrm{~N} / 04.00 \mathrm{E}-35 \mathrm{~L} 02 \mathrm{M}$ & - & 48N04E35L002M & 48704 & $419568 \mathrm{~N} 1214809 \mathrm{~W} 001$ \\
\hline 42 & California & $48.00 \mathrm{~N} / 05.00 \mathrm{E}-36 \mathrm{~A} 02 \mathrm{M}$ & - & 48N05E36A002M & 36329 & 419614N1213411W001 \\
\hline
\end{tabular}

\section{Agricultural Drain Flow Analysis}

To estimate changes in groundwater discharge to drains, an analysis was performed on spill and drain pumping data provided by the KID and TID, respectively. Changes in drain flow since 2000 are calculated as the difference between the 2012 drain pumpage and the 1997-2000 average drain pumpage, after accounting for operational and back spills. The 1997-2000 average drain pumpage is the best available data for estimating the volume of water pumped from the drains prior to 2001, when groundwater pumping increased significantly in response to shortages of surface water. Because the drain pumping data are used as a proxy for drain flow, the following paragraphs will reference drain flow rather than pumpage.
In the North TID/KID area, drain flow decreased by 22,300 acre-ft from the average 1997-2000 flow to 2012 flow (fig. 11).

The area with the next greatest change in drain flow is the Copic Bay area, where 2012 drain flows were about 7,300 acre-ft less than the 1997-2000 average after following an approximate linear decrease (fig. 12).

In the Lease Lands area, drain flow decreased by 2,800 acre-ft between 2000 and 2012 (fig. 13). Unlike the North TID/KID and Copic Bay areas, no clear long-term trend in drain flow is apparent in this area. On a long-term average basis, the change in Lease Lands drain flow has been minor.

The drain analysis shows that drain flow has decreased from 2000 to 2012. In total, the drain flows from the three areas in 2012 is about 32,400 acre-ft less than the 1997-2000 average. 


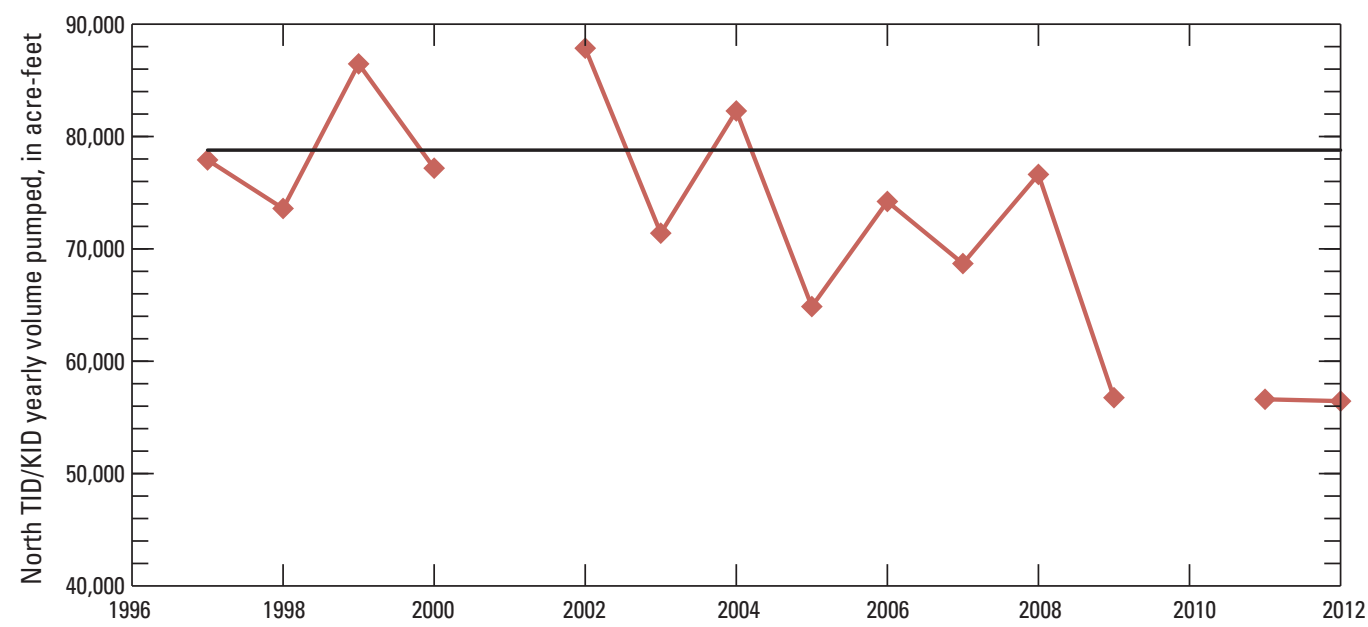

Figure 11. Yearly volume of water from pumps integrating the North Tulelake and Klamath Irrigation District (TID/KID) subarea, Oregon and California. Reference line shows average 1997-2000 pumping. Data for 2001 and 2010 were omitted because of the effects of severely curtailed surface-water deliveries during those years.

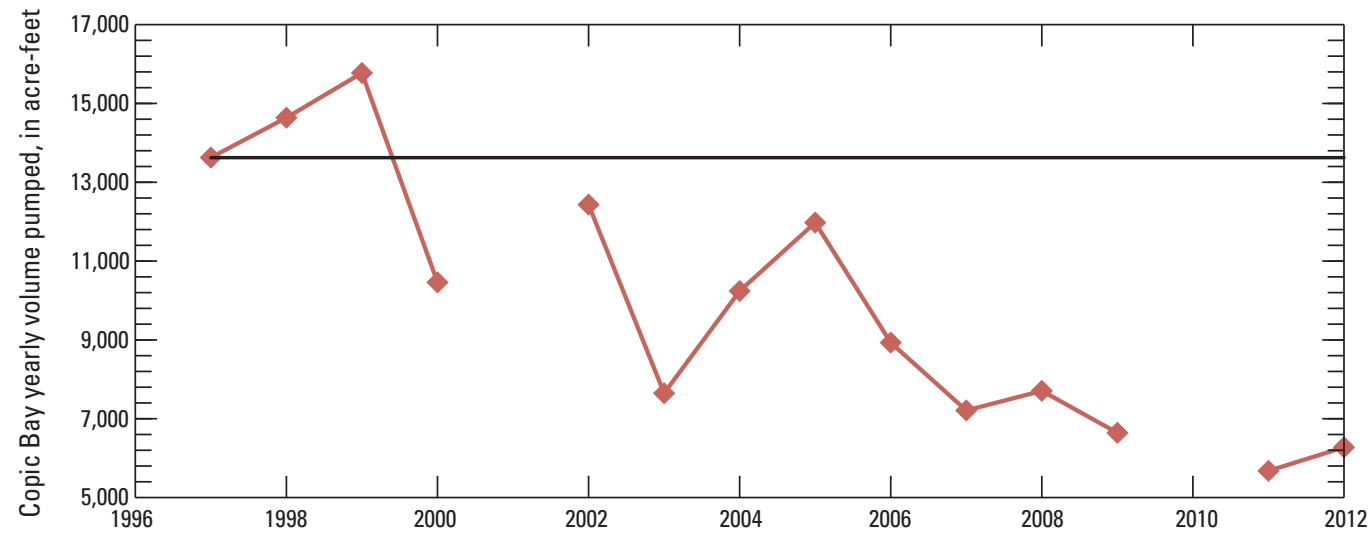

Figure 12. Yearly volume of water from pumps integrating the Copic Bay subarea, Tule Lake subbasin, California. Reference line shows average 1997-2000 pumping. Note the scale change between this and graphs for the other subareas. Data for 2001 and 2010 were omitted because of the effects of severely curtailed surface-water deliveries during those years.

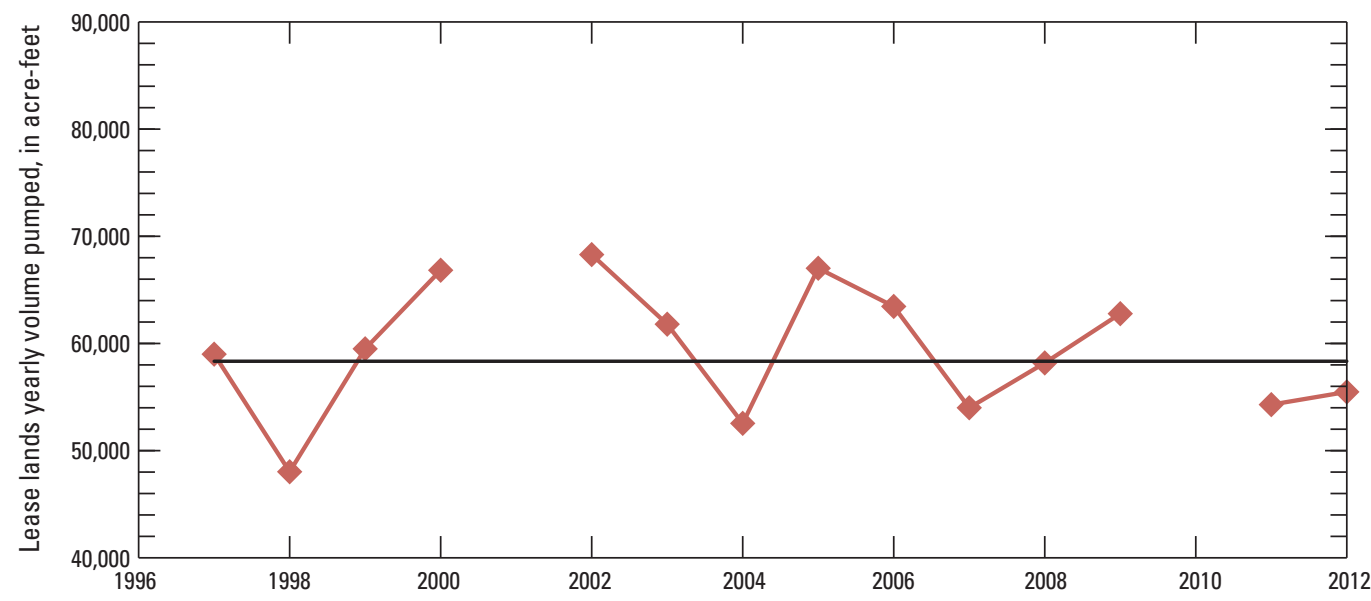

Figure 13. Yearly volume of water from pumps integrating the Lease Lands subarea, Tule Lake subbasin, California. Reference line shows average 1997-2000 pumping. Data for 2001 and 2010 were omitted because they were drier-than-average years and do not reflect typical conditions. 


\section{Groundwater Model Results}

\section{Calibration}

The purpose of model calibration is to determine the model structure and parameter values that provide the best fit between measured and simulated values. The final parameter values (table 4) are within ranges estimated in previous studies (for example, Gannett and others, 2012). HK, VANI, and SS parameters for each geology type have the same name in both the upper Klamath regional and Tule Lake models, except SS for Tsy and Tsv. These have each been split into two parameters for the upper and lower aquifers, as discussed previously in section, "Model Calibration."

Some parameter values differ between the Tule Lake model and the upper Klamath Basin regional groundwater model of Gannett and others (2012). The SS parameter values for the Tsv unit are smaller than values for the same geology type in the upper Klamath Basin regional model. Values of storativity (the product of specific storage and aquifer thickness) are, however, within reasonable ranges. The SS parameter of the Tsv unit is split between the upper part (SS_TSVU; layers 1-4) and the lower part (SS_TSVL; layers 5-12) of the model. Storativity values for the upper layers range from $1 \times 10^{-6}$ to $2 \times 10^{-6}$. These are slightly less than the typical range of values for confined aquifers $\left(10^{-5}\right.$ to $\left.10^{-3}\right)$. However, because there are no observation wells to inform the model about water level changes in the upper part of the Tsv unit, the model is not sensitive to this parameter (fig. 14), meaning it has little effect on calibration results. Storativity values for the lower layers range from $2 \times 10^{-6}$ to $3 \times 10^{-5}$. The arithmetic mean of Tsv storativity values for the lower eight layers of the model is $1.3 \times 10^{-5}$, a typical value for storativity in a confined volcanic aquifer (Freeze and Cherry, 1979) and comparable to the regional model. High SS_QS and SS_QV parameters reflect unconfined conditions near land surface.

The vertical anisotropy parameter (which controls the ratio of horizontal to vertical hydraulic conductivity) for the Qs unit is two orders of magnitude different between the regional and Tule Lake models (17.6 and 5,290, respectively). Both values, however, are within reasonable ranges for sedimentary deposits. The high value of vertical anisotropy in the Tule Lake model is reasonable given the nature of the Quaternary deposits in the basin. Lake sediments are typically stratified with alternating coarse-and fine-grained deposits, which means that water is more likely to flow horizontally through the coarse-grained deposits than vertically through the lower permeability fine-grained deposits. Due to the relatively coarse vertical discretization, the regional model could not simulate the shallow vertical head gradients and was relatively insensitive to the vertical anisotropy of Quaternary sediments (see Gannett and others, 2012, fig. 11). Because of the finer vertical discretization, the Tule Lake model is better able to simulate vertical head gradients. The high vertical anisotropy in the Quaternary sediments (which are in only the upper $25 \mathrm{ft}$ of the model) resulted in more accurate simulation of the observed downward vertical head gradients.

Table 4. Calibrated values of parameters for the Tule Lake subbasin groundwater flow model, Oregon and California.

[Abbreviations $\mathrm{ft} / \mathrm{s}$, foot per second; $\mathrm{ft}^{-1}, 1 /$ foot]

\begin{tabular}{|c|c|c|c|c|}
\hline Parameter type & Zone or boundary & Label & Value & Unit \\
\hline Hydraulic conductivity & Quaternary sedimentary rocks & HK_QS & $1.59 \mathrm{E}-3$ & $\mathrm{ft} / \mathrm{s}$ \\
\hline Vertical anisotropy & Quaternary sedimentary rocks & VANIIQS & $5.29 \mathrm{E}+3$ & Dimensionless \\
\hline Hydraulic conductivity & Quaternary volcanic rocks & HK_QVV & $9.90 \mathrm{E}-5$ & $\mathrm{ft} / \mathrm{s}$ \\
\hline Vertical anisotropy & Quaternary volcanic rocks & VANI_QV & $1.14 \mathrm{E}+1$ & Dimensionless \\
\hline Specific storage & Quaternary volcanic rocks & SS_QV & $9.92 \mathrm{E}-4$ & $\mathrm{ft}^{-1}$ \\
\hline Specific storage & Tertiary basin-filling sediment_-Layers $2-4$ & SS_TSYYU & $7.46 \mathrm{E}-5$ & $\mathrm{ft}^{-1}$ \\
\hline Specific storage & Tertiary basin-filling sediment-Layers 5-11 & SS_TSYL & $6.76 \mathrm{E}-5$ & $\mathrm{ft}^{-1}$ \\
\hline Hydraulic conductivity & Tertiary sediments and volcanics & HK_TSV & $3.25 \mathrm{E}-5$ & $\mathrm{ft} / \mathrm{s}$ \\
\hline Vertical anisotropy & Tertiary sediments and volcanics & VANI_TSV & $1.14 \mathrm{E}+1$ & Dimensionless \\
\hline Specific storage & Tertiary sediments and volcanics-Layers $1-4$ & SS_TSVU & $3.92 \mathrm{E}-8$ & $\mathrm{ft}^{-1}$ \\
\hline Muliplier & Drain conductance & DRN_COND & $2.94 \mathrm{E}+1$ & Dimensionless \\
\hline Muliplier & Recharge & RECḦARGE & $1.00 \mathrm{E}+0$ & Dimensionless \\
\hline Muliplier & Riverbed conductance & RIV_COND & $1.00 \mathrm{E}-2$ & Dimensionless \\
\hline
\end{tabular}




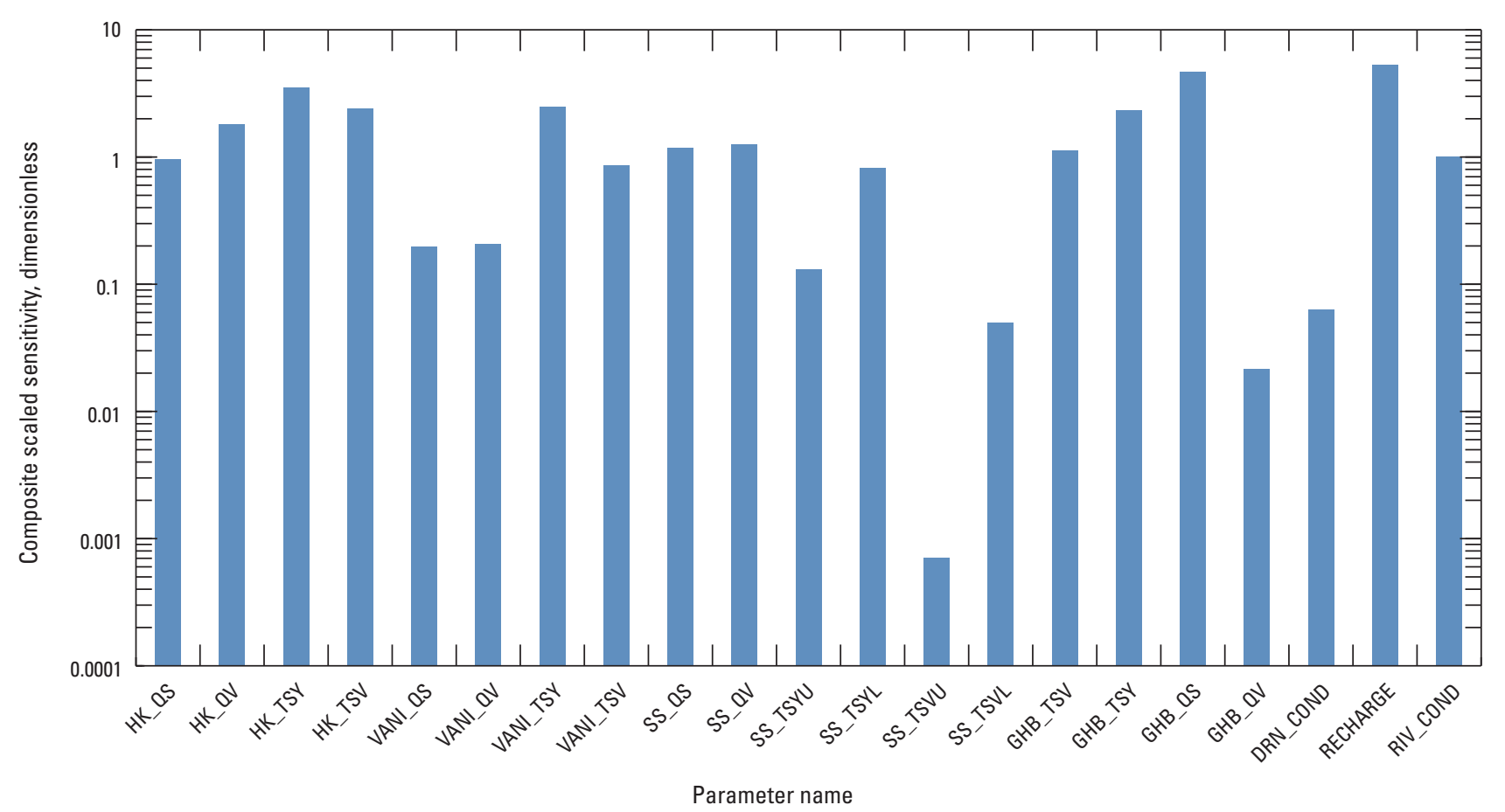

Figure 14. Composite scaled sensitivities of parameters in the Tule Lake groundwater model. Parameter names are defined in table 4.

The values for the hydraulic conductivity and vertical anisotropy of the Tertiary sediments of younger basins (basin fill: HK_TSY, VANI_TSY) for the regional and Tule Lake models are different by one order of magnitude $\left(2.9 \times 10^{-}\right.$ ${ }^{4}$ and $2.7 \times 10^{-5}$, respectively for HK TSY, and 250 and 62 , respectively for VANI_TSY). Although the values are different, the ratio of HK:VANI, which is equivalent to the vertical hydraulic conductivity, is nearly the same. Although the hydraulic conductivity values for the basin fill are different by an order of magnitude, both are within the typical range for sedimentary aquifers (Freeze and Cherry, 1979).

Other values of hydraulic conductivity in the model are within the typical range for their respective geology types (Freeze and Cherry, 1979), and SS values other than those for Tsv are reasonably close to values in the regional model (Gannett and others, 2012). Other parameters include the conductance of the drains, the bed of the Lost River, and the general head boundaries. These parameters, like the HK, VANI, and SS parameters, were optimized during parameter estimation to find the best match between observed and simulated hydraulic head values. Recharge parameter values were not changed during calibration.

\section{Parameter Sensitivity}

MODFLOW calculates the scaled sensitivity of each observation to each parameter and a composite scaled sensitivity for each parameter (see Hill, 1998, eqs. 8-10, p. 14-15, for the calculation of scaled sensitivities and composite scaled sensitivities). The composite scaled sensitivity is a measure of the total information provided by the observations for the estimation of a particular parameter (Hill, 1998). Parameters that have sensitivities that are significantly lower (more than two orders of magnitude) than other parameters are considered to be relatively insensitive; that is, the parameter value can change significantly without substantially changing model fit. The composite scaled sensitivities of parameters in the Tule Lake model are shown in figure 14. Most parameters are within two orders of magnitude, except SS_TSVU, the specific storage of the lower part of the aquifer composed of Tertiary sediments and volcanics. The insensitivity of this parameter is due in part to the few observations available to constrain it. The model was most sensitive to Recharge, GHB_QS, and HK_TSY.

\section{Model Fit}

The fit between simulated and observed values can be evaluated using graphical analysis of residuals, diagnostic statistics, and graphical inspection of observed and simulated hydraulic head plots (Hill, 1998). To identify possible error and bias in the model, it is also useful to evaluate the patterns of model residuals (observed minus simulated hydraulic heads).

Residuals from the Tule Lake model plotted with weighted simulated hydraulic-head values (fig. 15) show a slight trend-hydraulic heads are overestimated with increasing simulated hydraulic-head value. Overall, there is a slight negative bias, indicating that simulated hydraulic-head values tend to be too high. This bias may be an artifact of 


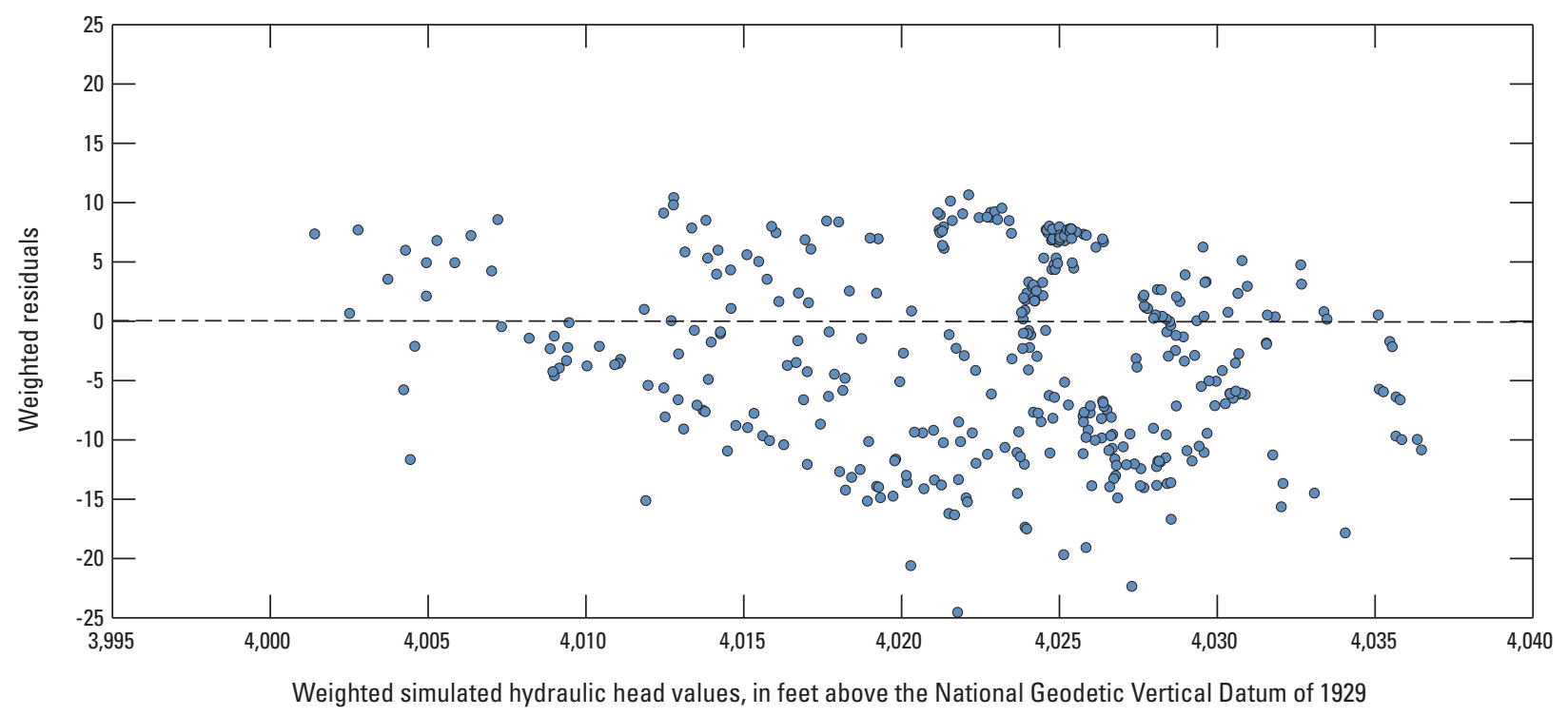

Figure 15. Weighted residuals (measured hydraulic head minus simulated hydraulic head) and weighted simulated hydraulic head values, Tule Lake subbasin, Oregon and California.

model discretization or because the generally drier climatic trend during the 2000s, which lowered observed hydraulic heads late in the simulation period, is not represented in the model.

Other statistical measures of model fit are the calculated error variance, standard error, and fitted standard error of the regression. These statistics provide means of assessing the average magnitude of model residuals (Hill, 1998). The calculated error variance, $\mathrm{s}^{2}$, is calculated as:

$$
s^{2}=\frac{S(b)}{(N-N P)}
$$

where

$\mathrm{S}(\mathrm{b})$ is the objective function value (equation 1),

$\mathrm{N}$ is the number of observations, and

NP is the number of estimated parameters (Hill, 1998).

The standard error of the regression, $\mathrm{S}$, is the square root of the calculated error variance. The smaller these values are, the closer the fit is to observed data. For the Tule Lake model, the calculated error variance, $s^{2}$, is 71.4. The standard error of the regression, $\mathrm{S}$, is 8.5 .

The fitted standard error of the regression is a more intuitive means of understanding the average magnitude of residuals (Hill, 1998). The fitted standard error of the regression is the product of the standard error of the regression and the statistic used to determine the weights. In the Tule Lake model, the statistic used to calculate weights was the standard deviation of the measurement error, $1 \mathrm{ft}$. The resulting fitted standard error of the regression is $8.5 \mathrm{ft}$. This means that over the entire active model domain, most simulated hydraulic head values are within about $8.5 \mathrm{ft}$ of the measured value.

\section{Comparison of Measured and Simulated Hydraulic Heads}

One goal of model calibration is to find an acceptable fit between simulated hydraulic-head values and field observations. During model calibration, focus was placed on matching springtime values of observed hydraulic head in order to match long-term trends in the data. Many shortterm fluctuations in the observed hydraulic heads reflect stresses that could not be accurately simulated in the model because of incomplete information on the geographic location and timing of pumping stresses. The long-term decreasing trend in hydraulic head is captured by the model in nearly all of the observation wells (figs. 16A-H). Simulated water level trends in some wells show recovery after 2007 (for example, figs. 16C-E). The simulated recovery may partly result from underestimates of pumping in 2008 and 2009. Although no supplemental groundwater was purchased by the Bureau of Reclamation or KWAPA during those years, the observed hydraulic head data show that there is a pumping signal, indicating that groundwater pumping continued (figs. 16D, E, and H). There is also a probable climate signal not accounted for in the model. To simplify the model, average recharge was assumed. There was, however, a drying trend in the upper Klamath Basin during the period of the simulation. The drying trend can be seen in wells outside the area affected by irrigation pumping (figs. 17A and B, about 80 mi north-northwest and $10 \mathrm{mi}$ southeast of the Tule Lake subbasin, respectively). The omission of this drying trend in the model may be partly responsible for the simulated water-level rise in some wells late in the simulation period. 


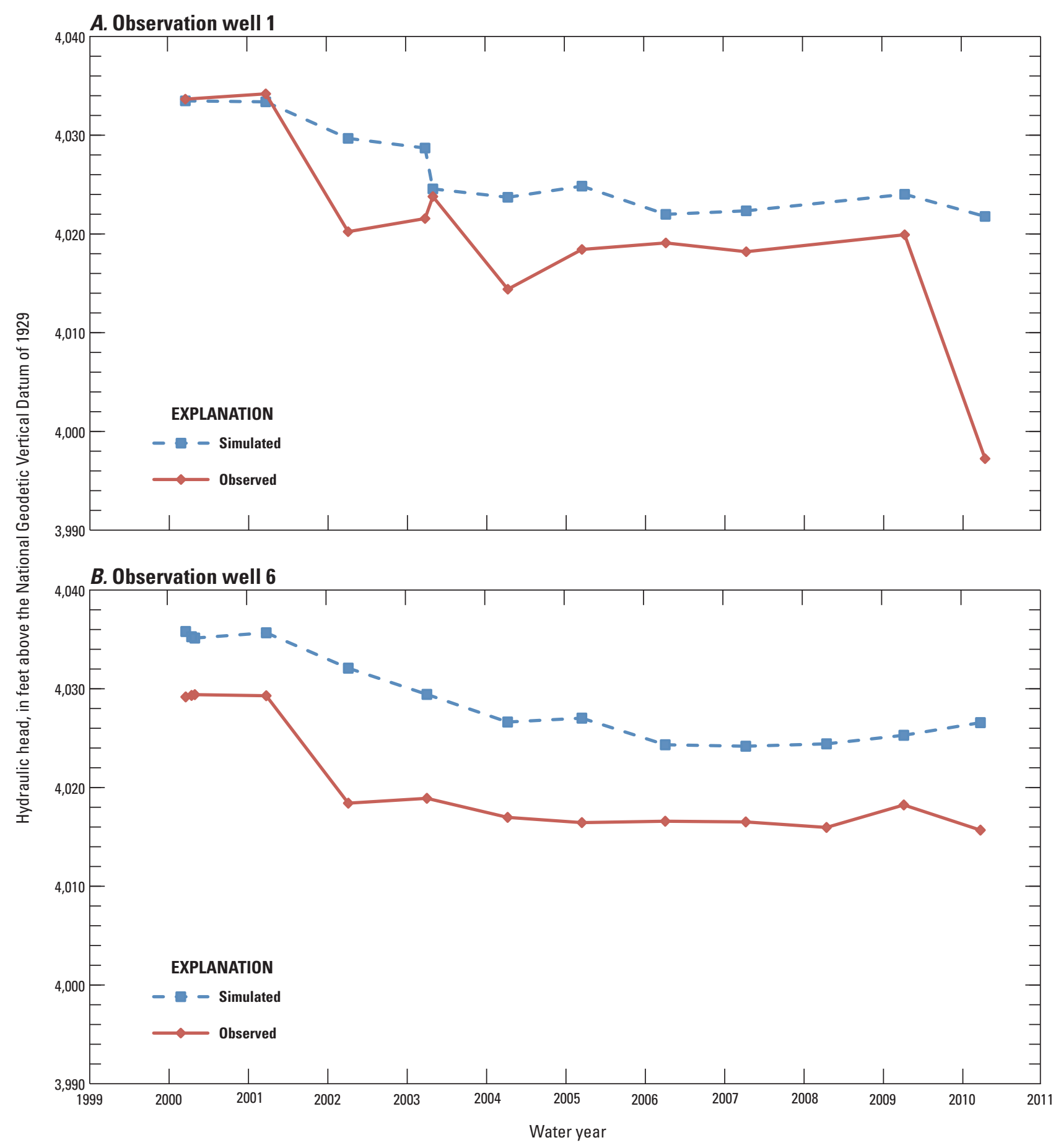

Figure 16. Observed and simulated hydraulic heads for selected observation wells, Tule Lake subbasin, Oregon and California. 


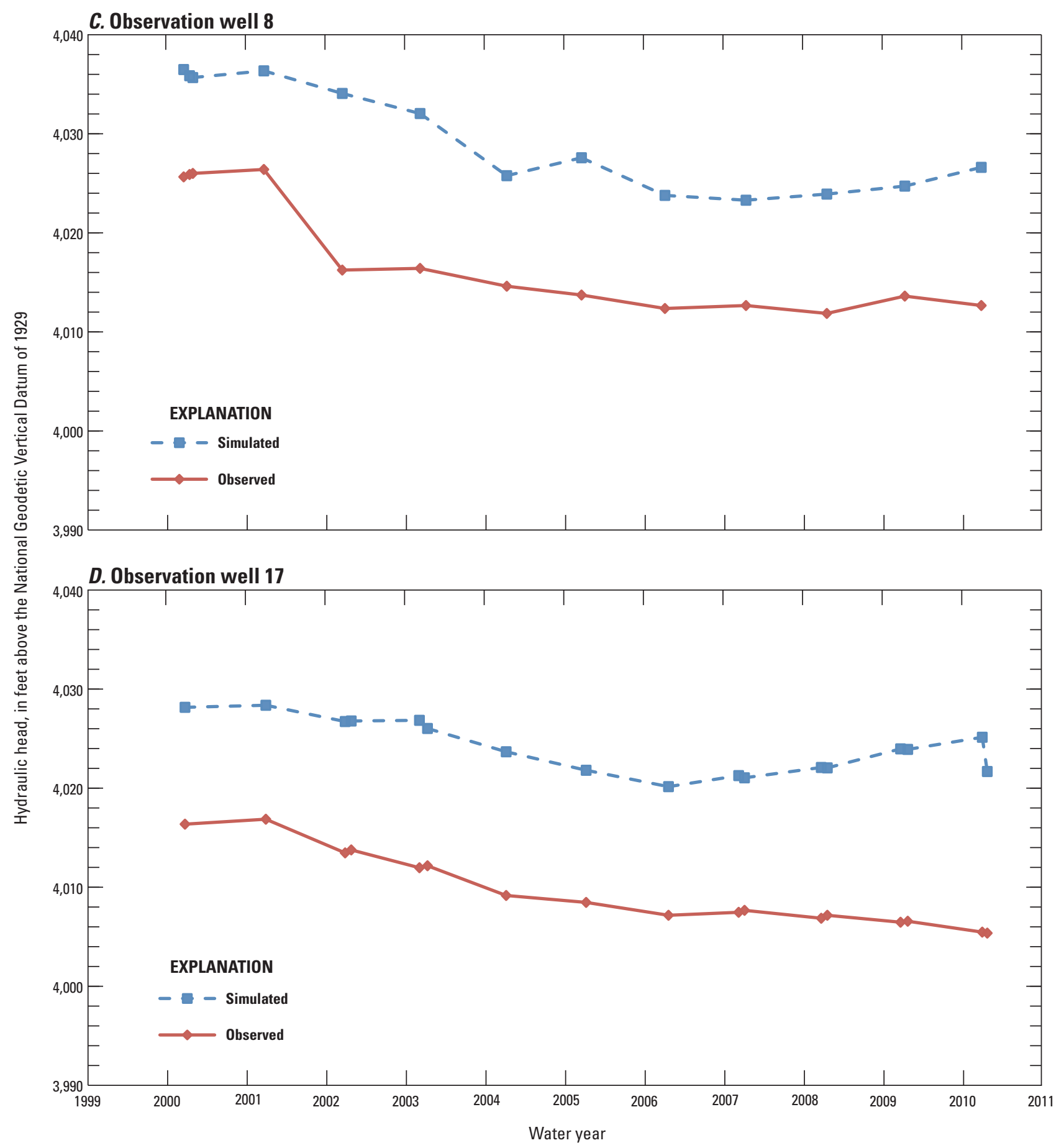

Figure 16.-Continued 


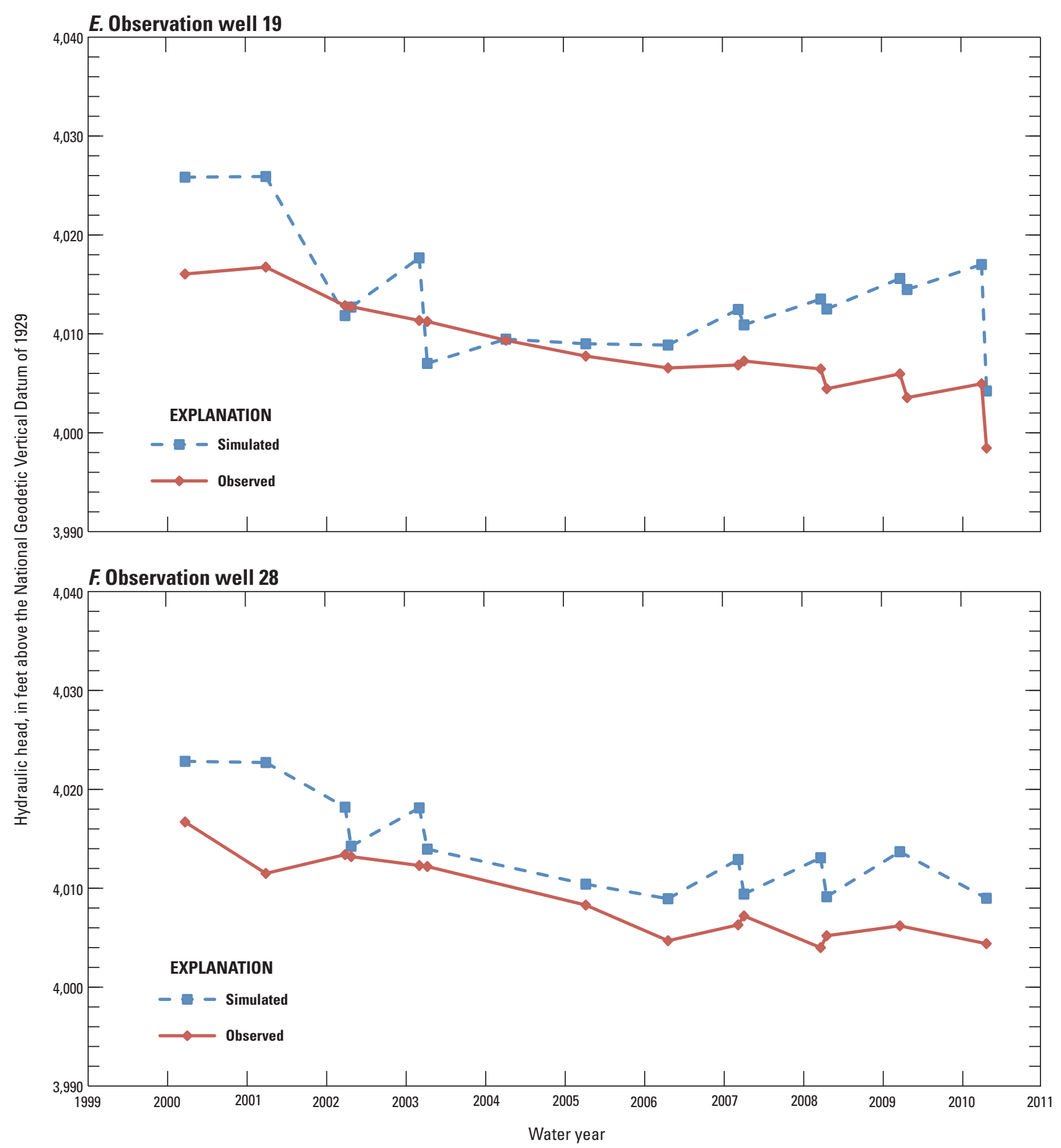

Figure 16.-Continued 


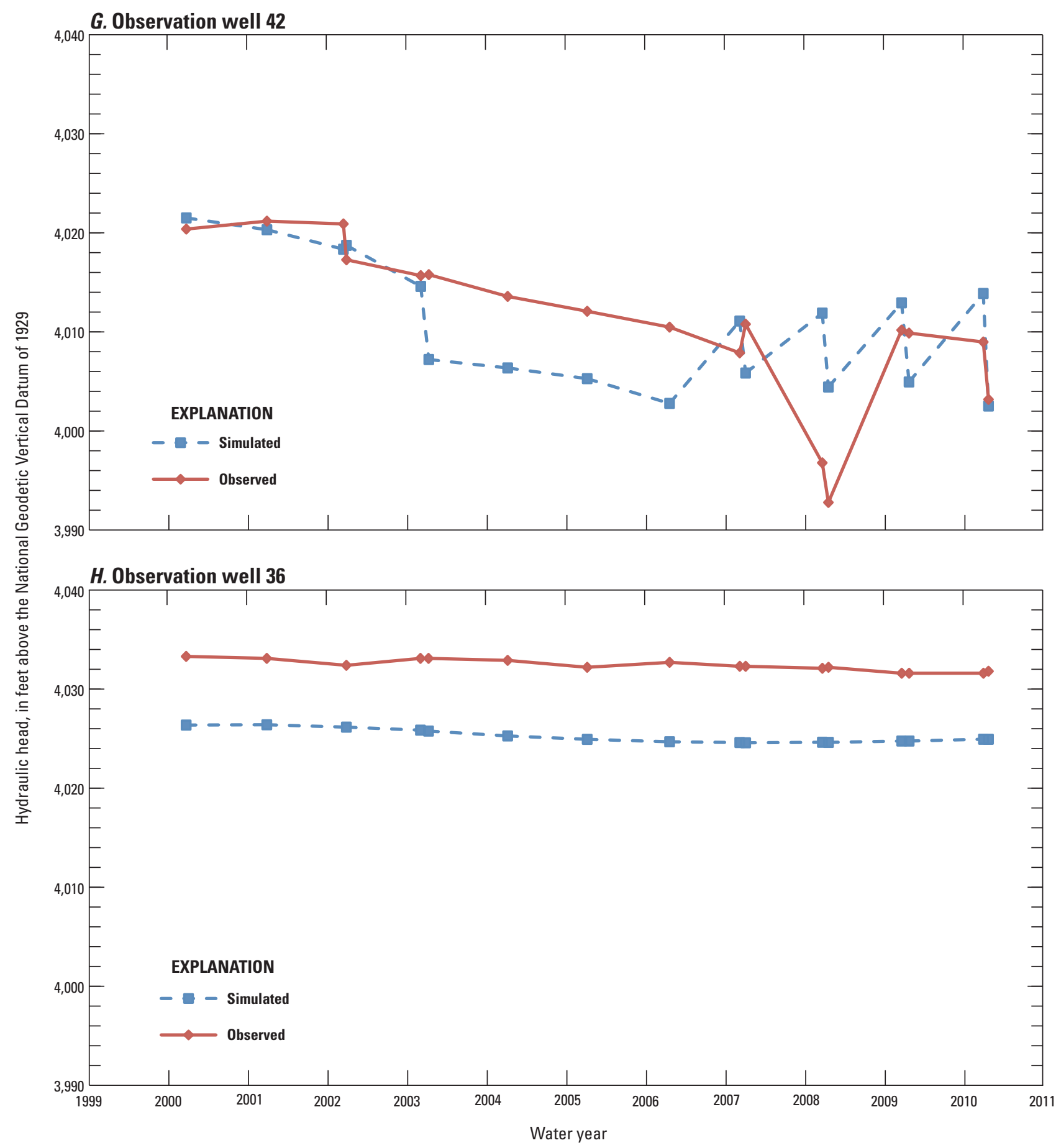

Figure 16.-Continued 


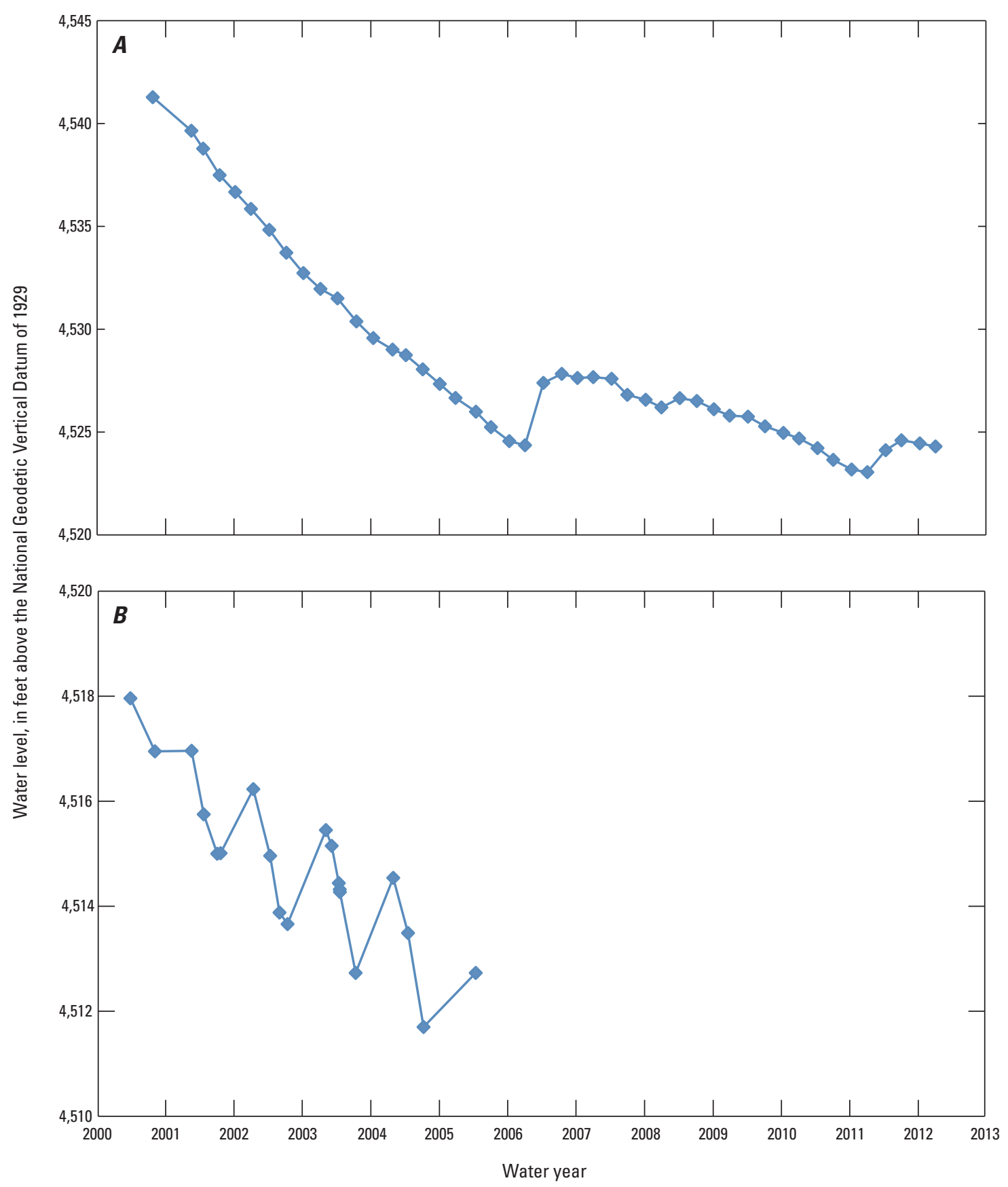

Figure 17. Water levels in U.S. Geological Survey observation wells $(A) 430837121473201$ (28.00S/08.00E-17DBC01), about 80 miles north-northwest of the Tule Lake subbasin, and $(B)$ 414043121155501 (44.00N/06.00E-03P01M), about 10 miles southeast of the Tule Lake subbasin, Oregon and California. 
The match between simulated and observed water levels varies from year to year in some wells, primarily because of uncertainty in the pumping data. The pumping rates for wells were provided, in some cases, as either an annual total for all wells or as totals for individual wells or groups of wells. The seasonal distribution of pumping is generally not known. Consequently, there is uncertainty as to the timing and spatial distribution of pumping. Simulated water levels reflect this uncertainty. Another potential cause of the difference between observed and simulated water levels is localized canal recharge. Recharge from irrigation in the model is distributed evenly over the irrigation district. In reality, some irrigation canals provide localized recharge to the groundwater system. Shallow wells near leaky canals show a signal from this recharge in their hydrographs. The spatial and temporal variability of canal leakage is not included in the model.

Like the simulated and observed hydraulic heads, the simulated and observed reduction in drain flow also can be compared (fig. 18). The observed decrease in drain flow is calculated from the summed decreased drain flow for the North KID/TID, Lease Lands, and Copic Bay subareas of the Tule Lake subbasin. To calculate drain flow decreases, the observed drain flow in 2000 was considered to be the base, pre-pumping condition, and the drain flow for each subsequent year (until 2010) was subtracted from the 2000 value.

Changes in simulated drain flows were calculated in a similar manner. Simulated decreases in drain flow in 2001 and 2010 were less than observed, likely because factors in addition to groundwater pumping, such as diminished interflow and surface runoff due to curtailed Project operations influenced drains as well. In years when supplemental groundwater pumping was the largest post-2000 stress on the system and effects due to drought and curtailed Project diversions played a relatively minor role, simulated and observed changes in drain flows are similar (fig. 18).

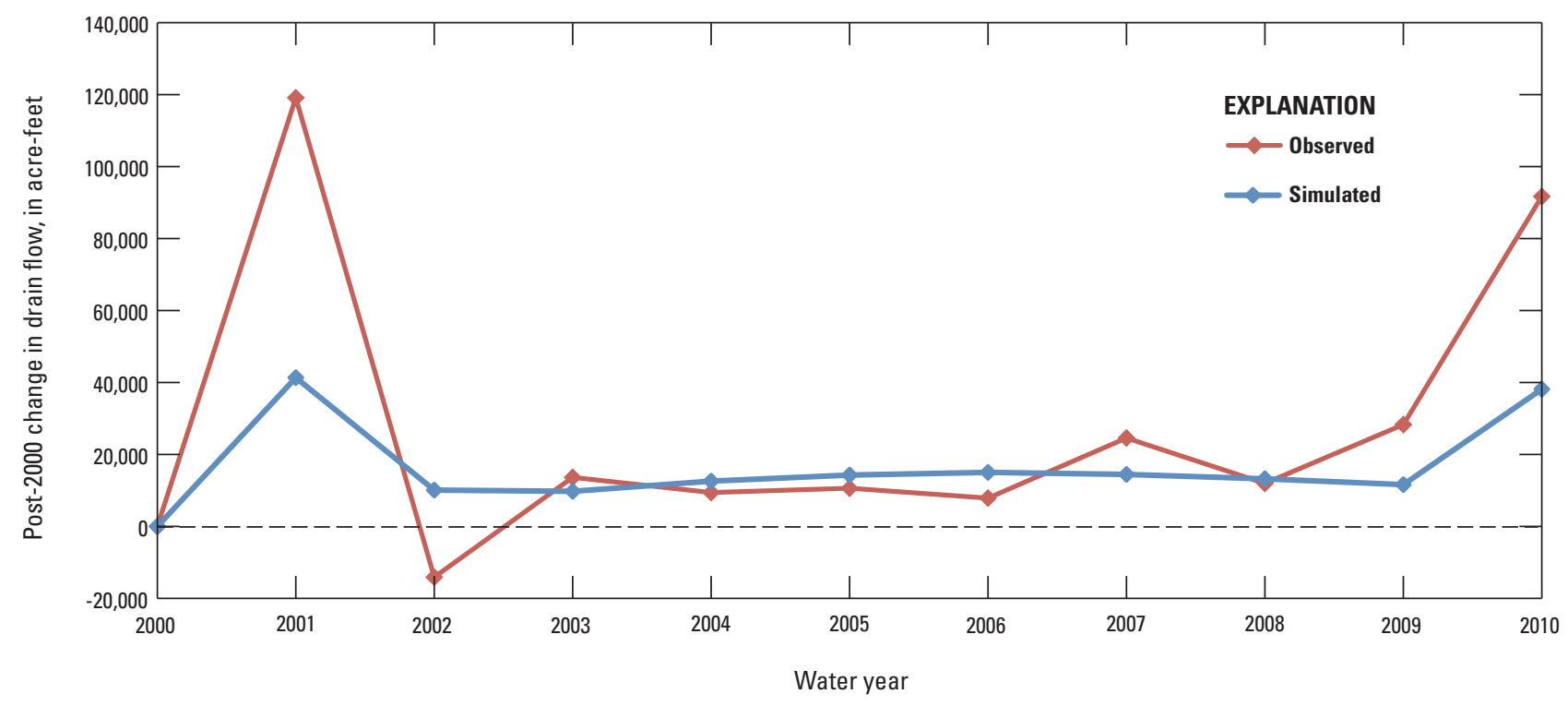

Figure 18. Observed and simulated decrease in flow to drains relative to drain flow in 2000, Tule Lake subbasin, Oregon and California. Observed decrease in flow to drains represents drain flow decreases from all three areas of the Tule Lake subbasin. 


\section{Simulated Hydrologic Budget and Sources of Water to Wells}

The groundwater model can be used to quantify the changes in groundwater flow to and from model boundaries such as drains, rivers, lakes, and adjacent basins, and to and from groundwater storage in response to pumping (fig. 19).

Recharge and pumping are specified in the model. Other flows, such as those to or from adjacent subbasins, drains, the Lost River, the Tule Lake sumps, and groundwater storage vary in response to these external stressors. Recharge is the largest budget component and, except for 2001 and 2010, is the same each year in simulations, varying seasonally.
Recharge was decreased in 2001 and 2010 to reflect diminished canal leakage and infiltration of applied irrigation water resulting from curtailed Project operations. Recharge was scaled back to 32 percent in 2001 and 55 percent in 2010 to reflect the diminished irrigation application those years. Recharge is positive in figure 19 because it represents a source of water. Pumping varies from year to year in response to demand for supplemental irrigation water and is shown as a negative value in figure 19 because it represents a sink for water.

The next largest flux of groundwater in the model is discharge to agricultural drains. Drains are the primary avenue by which groundwater leaves the model. Like pumping, the drain flux is negative because it represents a sink for water.

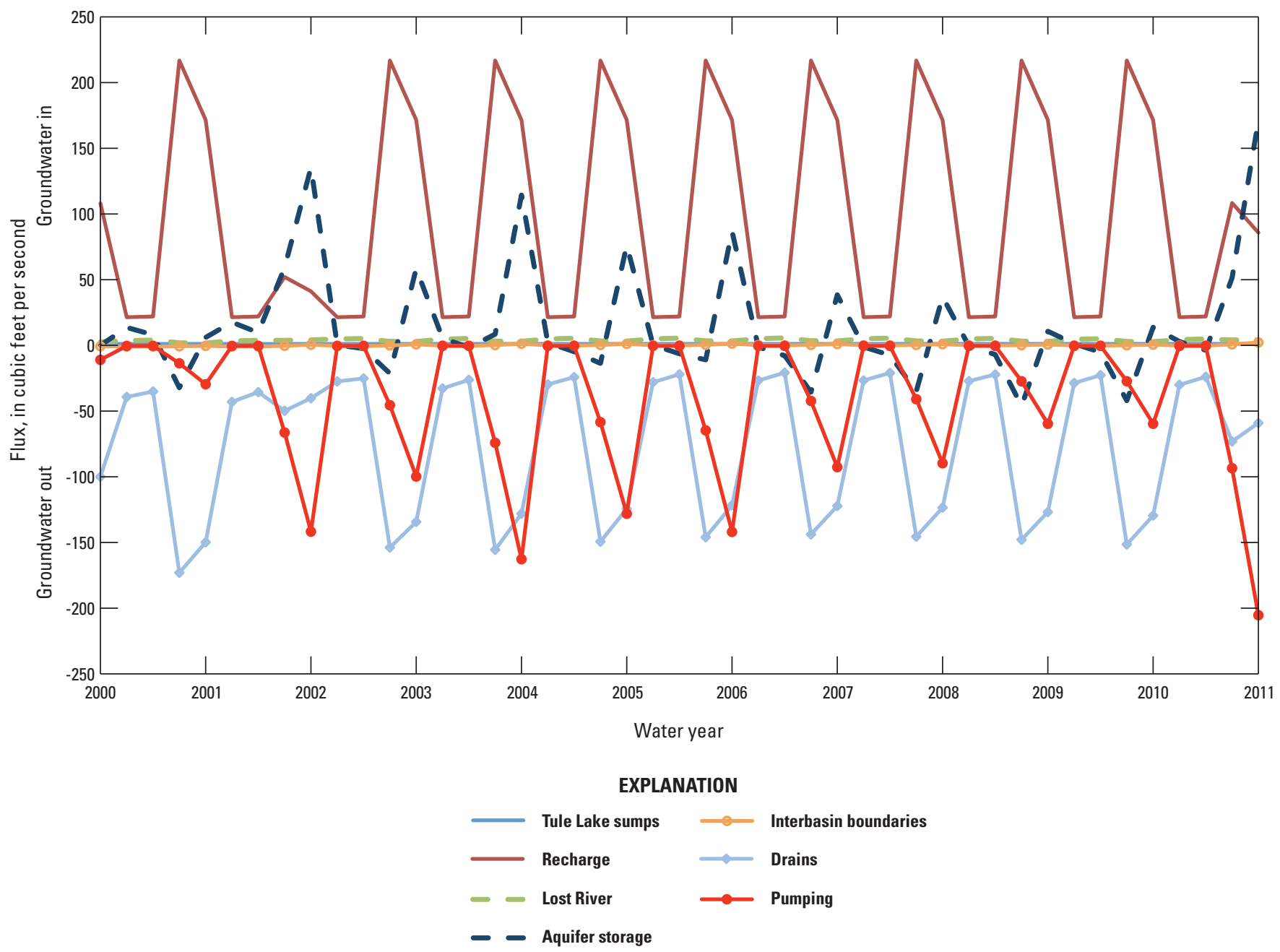

Figure 19. Simulated water budget components of the Tule Lake subbasin, Oregon and California. 
The remaining major flux is net change in aquifer storage, which represents the change in water stored in the aquifer over time. Storage is the only flux that can be either positive or negative. A positive value indicates that storage is a source of water (commonly to wells) and is reflected as a water-level decline. A negative value indicates that water (commonly from recharge) is going into storage, which results in a rising water level. Other components such as interbasin flow, and net flow to other surface water bodies (Lost River and Tule Lake sumps), are small in comparison.
The major budget components of the model changed during the simulation period in response to changes in recharge and pumping. During the first years of the simulation (2001-05) the storage term was mostly positive, indicating that water was coming from storage in response to increased pumping and decreased recharge in 2001. Groundwater levels declined during this period. From 2006 to 2010 changes in storage fluctuate closely around zero, indicating that pumped groundwater was coming mostly from diminished drain flows.

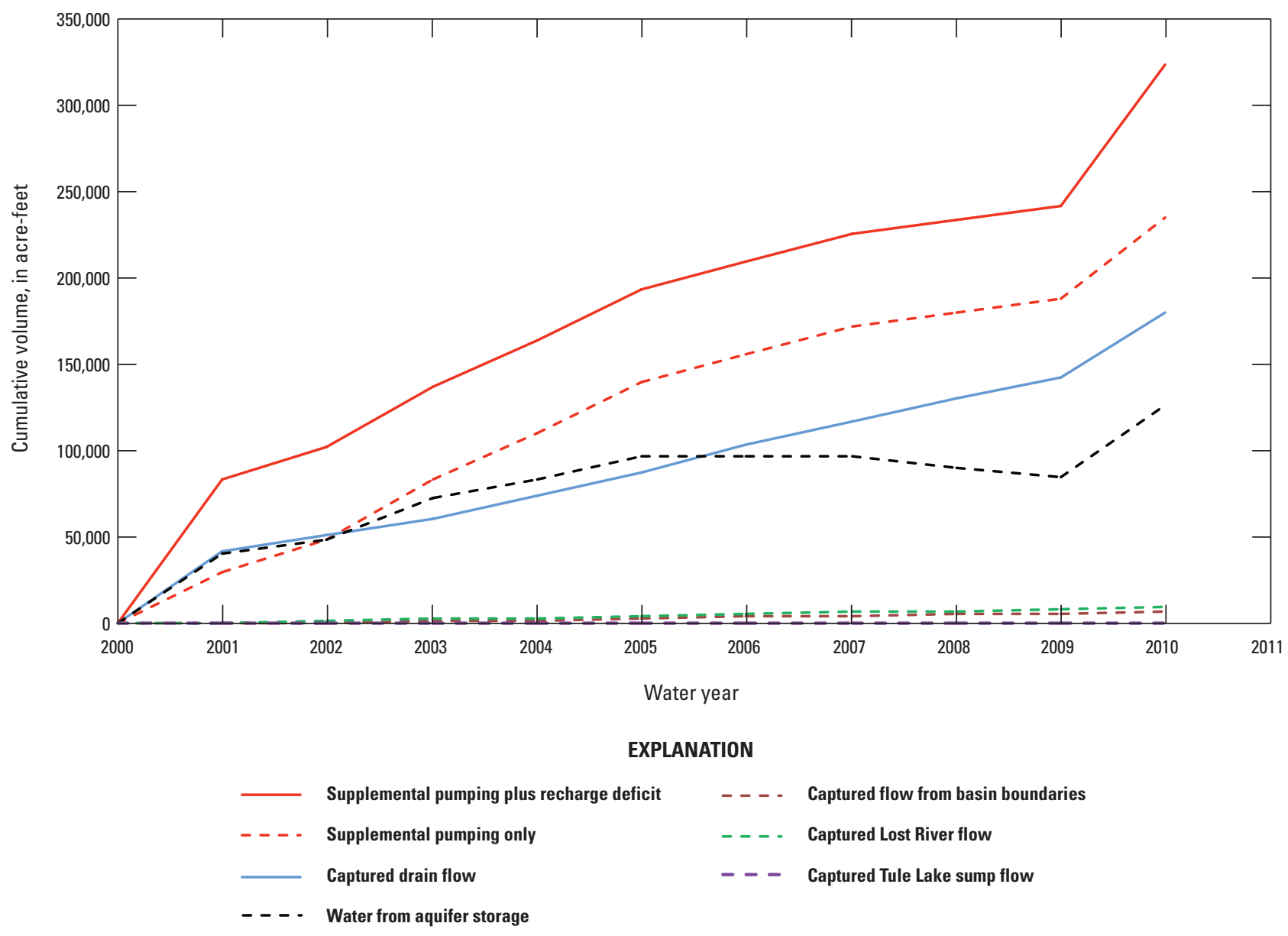

Figure 20. Simulated cumulative change in volume of selected budget components of the Tule Lake subbasin, Oregon and California. 
Groundwater levels were mostly stable during this period. Aquifer storage spiked positively again in 2010 in response to diminished recharge resulting from curtailed Project operation due to drought and to a large increase in pumping. Water levels declined sharply as a result.

Another representation of each budget component can be seen in figure 20. Whereas figure 19 shows the instantaneous rates of flow associated with each budget component at the end of each model stress period, figure 20 shows the cumulative volumes of these budget components. The line representing cumulative supplemental pumping plus the recharge deficit represents the total stress on the groundwater system. The recharge deficit is the stress on the groundwater system resulting from decreases in recharge. As the total stress is imposed on the groundwater system, the other model boundaries (agricultural drains, aquifer storage, interbasin boundaries, the Lost River, and the Tule Lake sumps) vary in response. Other lines in figure 20 show the cumulative change in storage and the cumulative volume captured from each model boundary due to supplemental pumping and decreased recharge in 2001 and 2010.

Annual water levels (groundwater storage), drain flows, and other boundary fluxes were relatively stable prior to 2001 because pumping was relatively constant. When pumping sharply increased and recharge diminished in 2001, aquifer storage and discharge to drains began to decrease as a result. This is shown in figure 20 as an increase in the volume captured from both drains and storage in 2001. Although simulated recharge returned to normal conditions after 2001, pumping remained above 2000 levels. The cumulative volumes of decreased, or captured, drain flow and storage tracked closely with cumulative supplemental pumping and decreased recharge, until about 2005 (fig. 20, table 5). From 2005 to 2009 , cumulative storage remains approximately constant (with the slope becoming slightly negative) indicating that storage was no longer a major source of water. At this point, most pumped water was from diminished groundwater discharge to drains. Another drought year (2010) led to a sharp increase in pumping and diminished recharge. This forced the system further out of equilibrium, resulting in sharp increases in captured drain flow and aquifer storage.

The sources of water most affected by groundwater pumping are agricultural drains and storage. The cumulative volume of supplemental pumping and reduced recharge (the
Table 5. Simulated cumulative change in volumetric budget, Tule Lake subbasin, Oregon and California.

[Negative values represent losses to the groundwater system. Positive values represent sources of water]

\begin{tabular}{lcc}
\hline \multicolumn{1}{c}{ Budget element } & $\begin{array}{c}\text { Cumulative } \\
\text { change } \\
\text { (acre-feet) }\end{array}$ & $\begin{array}{c}\text { Totals } \\
\text { (acre-feet) }\end{array}$ \\
\hline Supplemental pumping & $-234,758$ & $-323,573$ \\
Recharge deficit & $-88,815$ & \\
\hline Aquifer storage & 126,089 & 323,180 \\
Drains & 180,596 & \\
Lost River & 9,471 & \\
Interbasin boundaries & 6,795 & \\
Tule Lake sumps & 229 & -393 \\
\hline \multicolumn{2}{c}{ Difference } & \\
\hline
\end{tabular}

total stress on the groundwater system) between 2000 and 2010 (which includes annual supplemental irrigation and diminished recharge in 2001 and 2010) totaled 323,573 acre-ft. Supplemental pumping is the primary stress on the system; of the 323,573 acre-ft of cumulative pumping and decreased recharge, 234,800 acre-ft (73 percent) resulted from increased pumping above 2000 levels (table 5). The response of the groundwater system to this change in stress included about 180,500 acre-ft of decreased groundwater discharge to drains (about 56 percent of the total stress) and a 126,000 acre-ft reduction in aquifer storage (which amounts to about 39 percent of the total stress and is reflected by groundwater level declines). The remaining 5 percent of the stress (about 16,500 acre-ft) is reflected as decreased groundwater flow to other boundaries, including the Lost River, the Tule Lake sumps, and interbasin flow.

The greatest decrease in discharge to drains occurs in the northern and southeastern parts of the study area (fig. 21) where pumping wells are concentrated. In areas where pumping does not occur, drain effects are much less. This is consistent with the results of the Klamath/Tulelake Irrigation District drain analysis, in which most of the effect to drains was observed in the northern and southeastern subareas. 


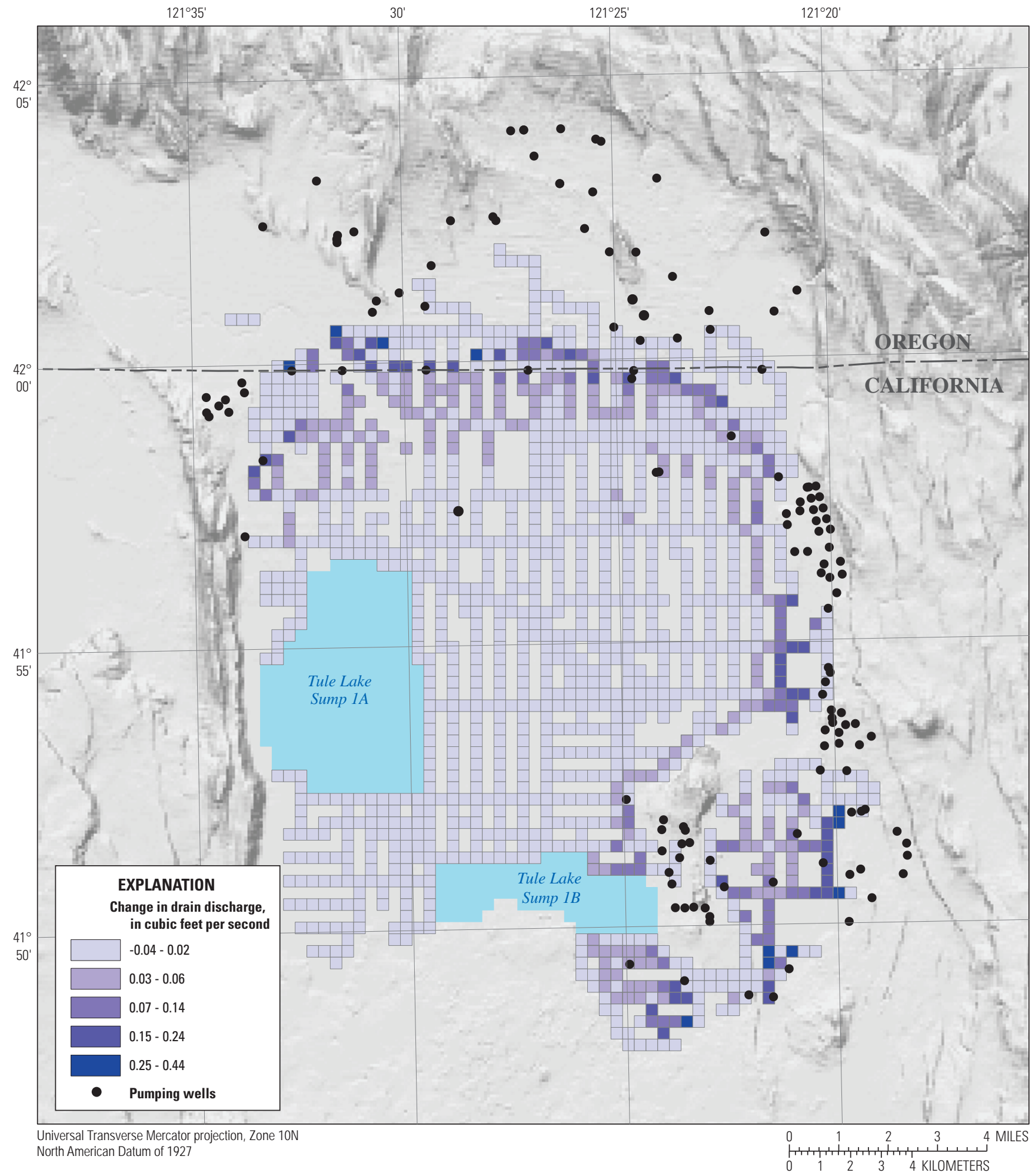

Figure 21. Spatial distribution of simulated reduction in discharge to drains, calculated as the discharge to drains in 2006 (year of maximum drain effect) subtracted from the discharge to drains in 2000, Tule Lake subbasin, Oregon and California. 


\section{Potential Implications}

Decreases in drain flow could affect water availability for the Lower Klamath and Tule Lake National Wildlife refuges. Irrigation return flows delivered by agricultural drains are the main source of water for both refuges. For water years 2003-05, the percentage of total inflow to the Lower Klamath and Tule Lake refuges from irrigation return flow was 67 and 75 percent, respectively. Because most of the water to both refuges is composed of return flow in drains, a decrease in this flow will affect both refuges.

Diminished drain flows could also affect downstream irrigators, including the TID. To date, growers who irrigate primarily with Project return flow from the drain system have not been affected by decreases in drain flow. With continued pumping and a drying climate, further reductions in drain flow are expected, which may require the TID to alter operations to meet the water demand of its member farmers. Recent management modeling by Wagner and Gannett (2014) suggests that practical and regulatory limits on drawdown in the aquifer would likely limit pumping before drain flows diminish to the point that there would be insufficient water to irrigate lands in the southern part of the Project.

The results of this study also have implications for the Project in a broader sense. In 2010, stakeholders in the basin developed an agreement that would balance the benefits of water for both aquatic wildlife and agriculture. The Klamath Basin Restoration Agreement (KBRA) (Klamath Basin Restoration Agreement, 2010) defines the limits on the "adverse impacts" of Project groundwater pumping on flow in certain streams and springs in the upper Klamath Basin to 6 percent of baseline flow (defined by pre-2001 pumping conditions). Drain data, along with the results of the groundwater model, show that the effects of Project pumping are largely limited to agricultural drains and changes in groundwater storage within the Project area, and that effects to KBRA listed streams, which are outside the Project area, are small or unlikely. This is consistent with the findings of Wagner and Gannett (2014), who showed that effects from probable future on-Project pumping to listed streams are well below the 6 percent limit.

\section{Study Limitations and Uncertainty}

\section{Uncertainty in the Drain-Flow Analysis}

The time series of volumes pumped from agricultural drains used in the drain-flow analysis were collected according to the operational needs of the Project or the irrigation districts. Estimates of volumes pumped from drains were determined using the pump rating and time of operation of each pump. Volumes of operational spills were determined using weirs and spill points. Water depths at weirs were sometimes estimated visually (Mark Stuntebeck, Klamath Irrigation District, oral commun., 2013). As such, there is uncertainty associated with these measurements.

The method by which changes in groundwater discharge to drains were estimated from pump data also introduced uncertainty. Water was pumped from the drains and reused in parts of the subbasin, so the drain flow analysis focused on three subareas with drain pumps that best integrate flow for each subarea to avoid double accounting of drain flow. However, some drain flow still may be accounted for more than once. Finally, the only quantifiable source of surface water available for this analysis was operational spill to drains from the KID. There may be other sources of surface water to drains, such as overland flow from precipitation or direct runoff from fields. Changes in unaccounted surface-water sources in this analysis could potentially affect estimates of the changes in the groundwater component of drain flow. Given that total diversions have not changed markedly, these other surface-water sources likely did not change during 2000-10.

\section{Uncertainty in the Groundwater Model}

Groundwater models are representations of complex natural systems. As such, simplifications must be made in order to create a practical groundwater model. Because the subsurface geology of the Tule Lake subbasin is complex and poorly known where well data are not available, it must be simplified and its structure inferred. For example, the boundary flow of groundwater into the Tule Lake subbasin from adjacent subbasins has not been directly measured. The final structure of the interbasin flow boundaries was determined by experimentation during model calibration. There was also uncertainty in the recharge and pumping data used in the model. Recharge in the model is based on a water balance by Burt and Freeman (2003), which itself used uncertain data. However, it is the best data available on recharge in the upper Klamath Basin. The pumping data used in the model is imprecise because the spatial distribution and seasonality of the pumping are poorly known. Additionally, unmeasured pumping took place during the study years, as evidenced by supplemental pumping signals in well hydrographs during 2008 and 2009, years when there was no supplemental pumping accounted for under government programs. In addition to data uncertainty, some processes could not be simulated with the model. The stresses that were not simulated were the decadal climate signal present in the upper Klamath Basin and localized recharge from leaky irrigation canals. Future work may include incorporating a climate signal within the modeled recharge and integrating localized recharge using the MODFLOW One-Water Hydrologic Flow Model (MODFLOW-OWHM), which simulates a wide range of processes relating to conjunctive use (Hanson and others, 2014). 


\section{Summary}

The allocation of water in the Tule Lake subbasin is challenging for resource managers and water users. Groundwater is used increasingly in the subbasin to make up for shortages due to reallocation of surface water for in-stream uses. U.S. Geological Survey regional groundwater flow model simulations and records of irrigation return flow pumped from the Tule Lake subbasin into the adjacent Lower Klamath Lake subbasin indicate that increased groundwater pumping has decreased the volume of shallow groundwater that discharges to agricultural drains. These drains, designed to convey excess irrigation water that percolates to the shallow subsurface, are an important source of water to downstream irrigators and are the primary source of water to the Lower Klamath and Tule Lake National Wildlife refuges. Changes in the volume of water discharging to drains and the causes of that change are of interest to water managers. The U.S. Geological Survey entered into a cooperative study with the Bureau of Reclamation and U.S. Fish and Wildlife Service to develop a quantitative evaluation of the connection between volcanic and overlying sedimentary aquifers in the Tule Lake subbasin of the Upper Klamath Basin to assess the effect of pumping on agricultural drains.

In the study, data from the Klamath Irrigation District (KID) and Tulelake Irrigation District (TID) were analyzed to quantify drain flow changes over time. Additionally, a groundwater model of the Tule Lake subbasin was constructed to integrate data regarding pumping, geology, structure of the subbasin, and proximity of stresses to other boundaries such as drains, the Lost River, the Tule Lake sumps, and interbasin flow margins to quantify how the interplay of these variables manifest as changes to drain flow.

Results of the drain flow analysis indicate that flow to agricultural drains had decreased since 2000. In all three subareas evaluated (North KID/TID, Copic Bay, and the Lease Lands), drain flows decreased to varying degrees. The greatest change occurred in the North KID/TID and Copic Bay subareas, where the differences between the 2012 drain flows and pre-2001 flows were 22,300 and 7,300 acre-ft, respectively. The Lease Lands showed a comparatively small overall change of 2,800 acre-ft. In total, combined drain flow for all three subareas in 2012 was approximately 32,400 acre-ft less than the pre-2001volumes.

In addition to increases in pumping, diminished recharge likely results in decreases in drain flows. Changes in recharge were probably a major influence on reduced drain flows in 2001 and 2010, dry years in which irrigation diversions were curtailed. This is evident in an analysis of the calculated and simulated yearly loss of groundwater flow to drains.
The groundwater model indicates that drain flows are being decreased primarily by groundwater pumping. Analysis of the model budget shows that in the early 2000s, pumped water is sourced from both groundwater storage and diminished groundwater discharge to drains, and with time the source shifts from aquifer-storage depletion to capture of agricultural drain flows. The Lost River, interbasin flow, and Tule Lake sumps all provide a comparably small amount of water to pumping wells.

Simulations and data show that the effect of supplemental pumping on drains remained relatively constant after 2001, and the contribution from groundwater storage began to decrease. The system was approaching a new equilibrium until 2010, when a large increase in pumping and decreased recharge resulted in increased reductions in drain flow and groundwater storage. These findings are consistent with what is known about the behavior of groundwater systems that undergo pumping stress.

\section{Acknowledgments}

The authors thank the following individuals for their help and their knowledge, both of which were keys to this study. Brad Kirby of the Tulelake Irrigation District and Mark Stuntebeck of the Klamath Irrigation District provided critical data on pump and drain flows, operational spills, and cropping patterns, and patiently explained the complex plumbing of their districts. The Bureau of Reclamation Klamath Basin Area Office provided information on Project operations and diversions, as well as funding for this effort. Tim Mayer of the U.S. Fish and Wildlife Service provided useful discussions on refuge water operations, and was instrumental in securing funding for the first year of the project. 


\section{References Cited}

Anderson, M.P., and Woessner, W.W., 1992, Applied groundwater modeling-Simulation of flow and advective transport: San Diego, Academic Press, 381 p.

Barlow, P.M., and Leake, S.A., 2012, Streamflow depletion by wells - Understanding and managing the effects of groundwater pumping on streamflow: U.S. Geological Survey Circular 1376, 84 p.

Freeze, R.A., and Cherry, J.A., 1979, Groundwater: Englewood Cliff, N.J., Prentice-Hall, 604 p.

Gall, I.K., 2011, Technical assistance for the U.S. Bureau of Reclamation water bank in the upper Klamath Basin, 2011: Oregon Water Resources Department Report prepared for the U.S. Bureau of Reclamation under agreement R10AC20099, 17 p., plus tables and appendices.

Gannett, M.W., Lite, K.E., Jr., La Marche, J.L., Fisher, B.J, and Polette, D.J., 2007, Ground-water hydrology of the Upper Klamath Basin, Oregon and California (ver. 1.1, April 2010): U.S. Geological Survey Scientific Investigations Report 2007-5050, 84 p.

Gannett, M.W., Wagner, B.J., and Lite, K.E., Jr., 2012, Groundwater simulation and management models for the upper Klamath Basin, Oregon and California: U.S. Geological Survey Scientific Investigations Report 2012-5062, 92 p.

Hanson, R.T., Boyce, S.E., Schmid, W., Hughes, J.D., Mehl, S.M., Leake, S.A., Maddock, Thomas, III, and Niswonger, R.G., 2014, One-Water Hydrologic Flow Model (MODFLOW-OWHM): U.S. Geological Survey Techniques and Methods 6-A51, $120 \mathrm{p}$.

Harbaugh, A.W., Banta, E.R., Hill, M.C., and McDonald, M.G., 2000, MODFLOW-2000, the U.S. Geological Survey modular ground-water model-User guide to modularization concepts and the Ground-Water Flow Process: U.S. Geological Survey Open-File Report 00-92, $121 \mathrm{p}$.

Hill, M.C., 1998, Methods and guidelines for effective model calibration: U.S. Geological Survey Water-Resources Investigations Report 98-4005, 90 p.

Hill, M.C., Banta, E.R., Harbaugh, A.W., and Anderman, E.R., 2000, MODFLOW-2000, The U.S. Geological Survey modular ground-water model-User guide to the observation, sensitivity, and parameter-estimation processes and three post-processing programs: U.S. Geological Survey Open-File Report 00-184, 209 p.
Klamath Basin Restoration Agreement (KBRA), 2010, Klamath Basin restoration agreement for the sustainability of public and trust resources and affected communitiesFebruary 18, 2010: Klamath Basin Restoration Agreement, 378 p., accessed January 17, 2012, at http:// klamathrestoration.gov/.

La Rue, E.C., 1922, Klamath River and its utilization: Salem, Oregon, Report to the Office of the State Engineer, 204 p.

McDonald, M.G., and Harbaugh, A.W., 1988, A modular three-dimensional finite-difference ground-water flow model: U.S. Geological Survey Techniques of WaterResources Investigations, book 6, chap. A1, 586 p.

National Research Council, 2004, Endangered and threatened fishes in the Klamath River Basin: National Research Council, 384 p.

Palmer, P.C., Gannett, M.W., and Hinkle, S.R., 2006, Isotopic characterization of three groundwater recharge sources and inferences for selected aquifers in the upper Klamath Basin of Oregon and California, USA: Journal of Hydrology, v. 336, 13 p.

Reilly, T.E., Dennehy, K.F., Alley, W.M., and Cunningham, W.L., 2008, Ground-water availability in the United States: U.S. Geological Survey Circular 1323, 70 p.

Risley, J.C., and Gannett, M.W., 2006, An evaluation and review of water-use estimates and flow data for the Lower Klamath and Tule Lake National Wildlife Refuges, Oregon and California: U.S. Geological Survey Scientific Investigations Report 2006-5036, 18 p.

Theis, C.V., 1940, The source of water derived from wellsEssential factors controlling the response of an aquifer to development: Civil Engineering, v. 10, no. 5, p. 277-280.

Wagner, B.J., and Gannett, M.W., 2014, Evaluation of alternative groundwater-management strategies for the upper Klamath Basin, Oregon and California: U.S. Geological Survey Scientific Investigations Report 2014-5054, 48 p. 


\section{Appendix A. Model Observation Wells}

Water-level measurements from 24 wells located throughout the Tule Lake subbasin were used to calibrate the Tule Lake subbasin groundwater model. Spring (March, or sometimes March and April) water levels were used to minimize error due to drawdown during pumping. A selection of these wells with observed and simulated water levels is shown in figure 16 . The remaining wells are shown in figure A1, which can be accessed as a PDF at http://pubs.er.usgs.gov/publication/sir20155087.

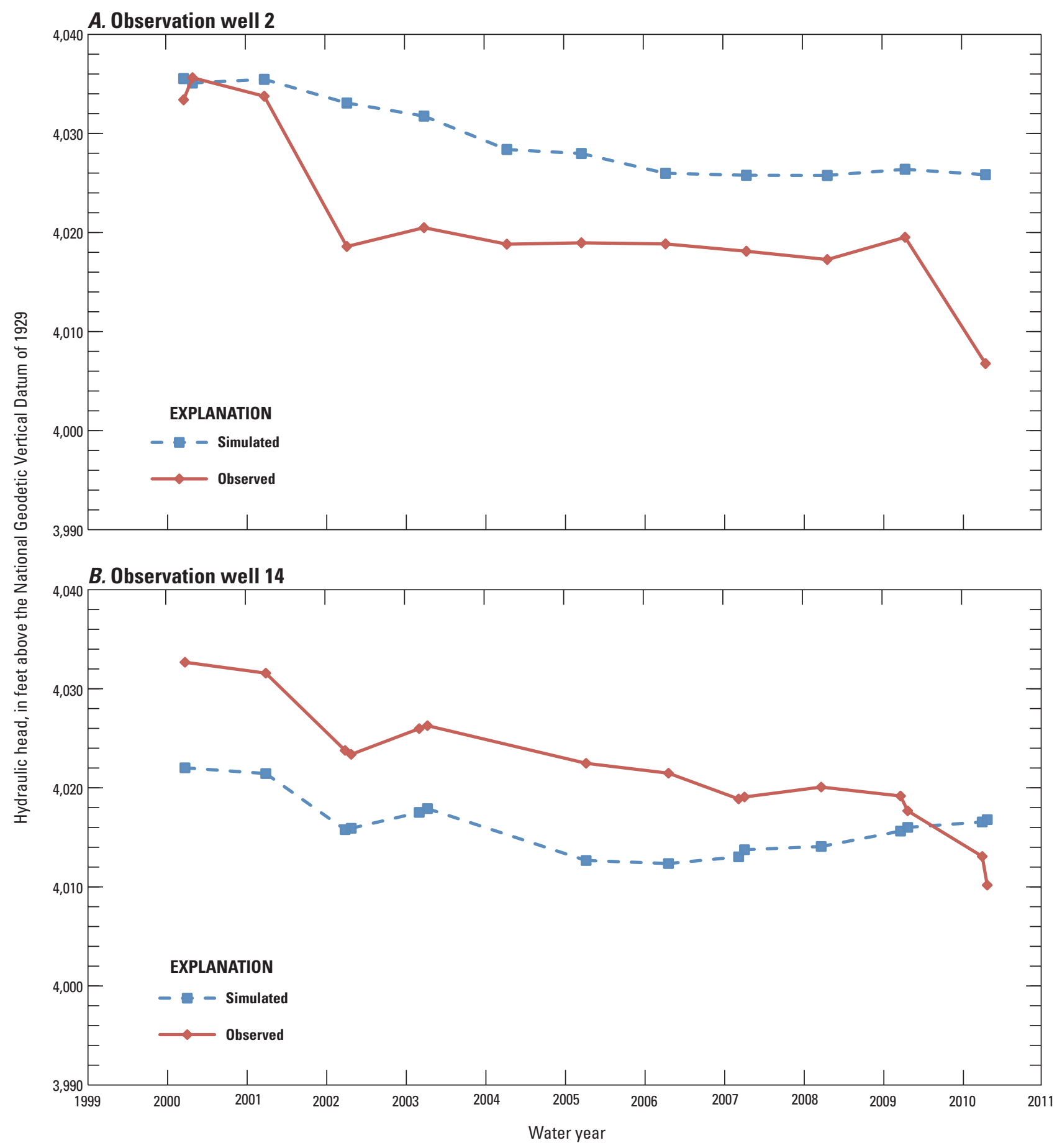

Figure A1. Simulated and measured hydraulic head data for the Tule Lake groundwater model, Tule Lake subbasin, Oregon and California, water years 2001-10. 


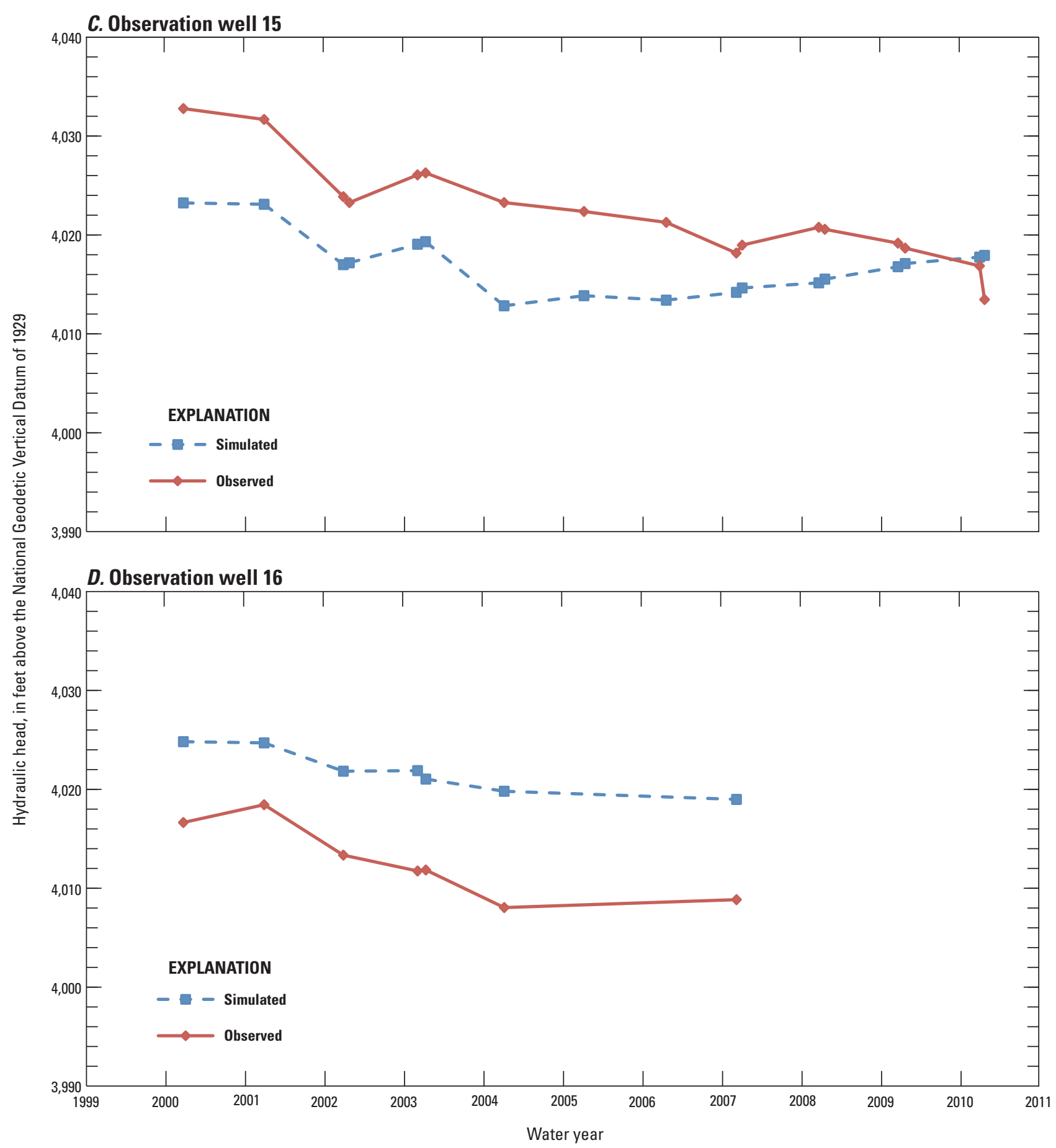

Figure A1.-Continued 


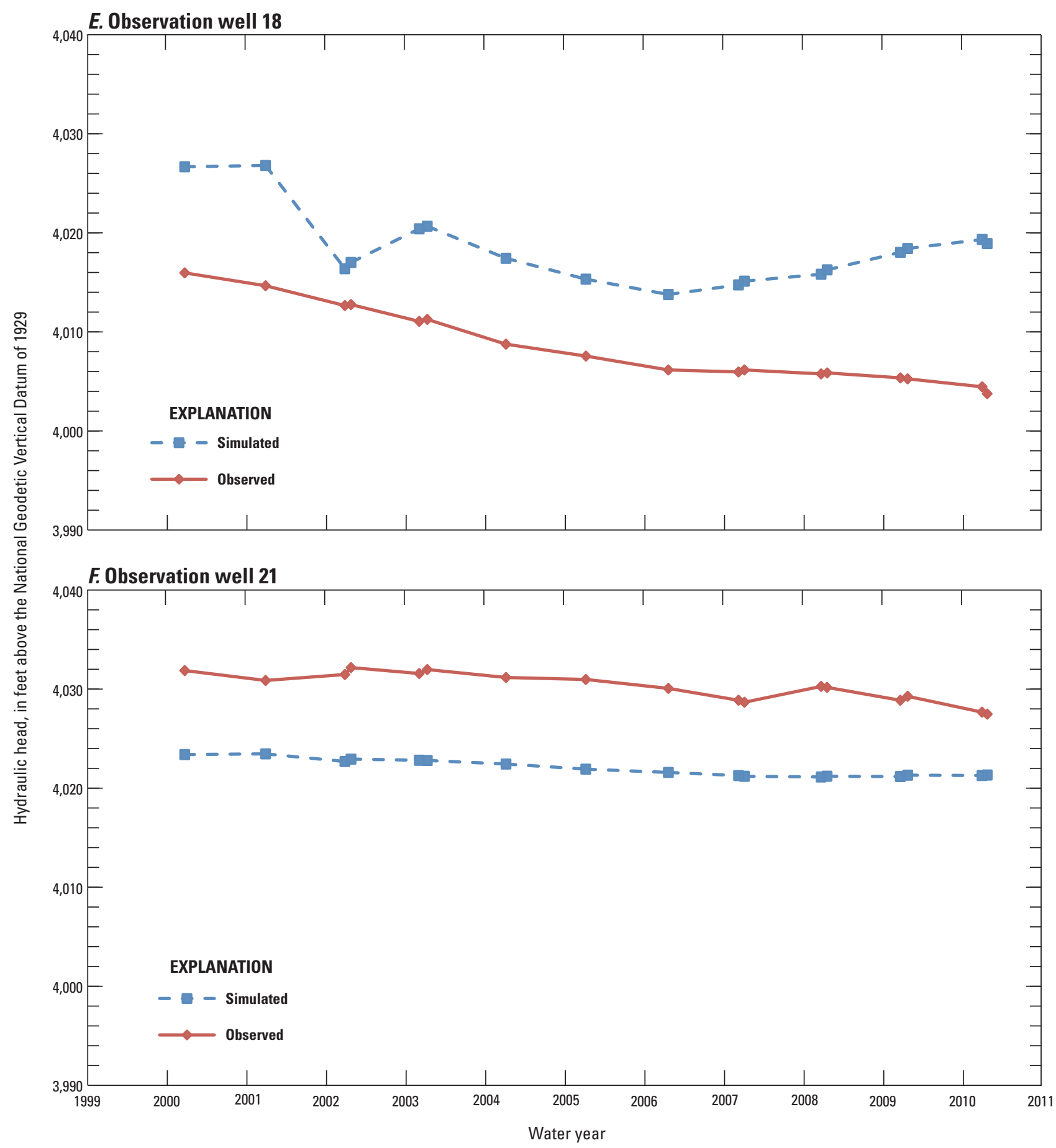

Figure A1. - Continued 


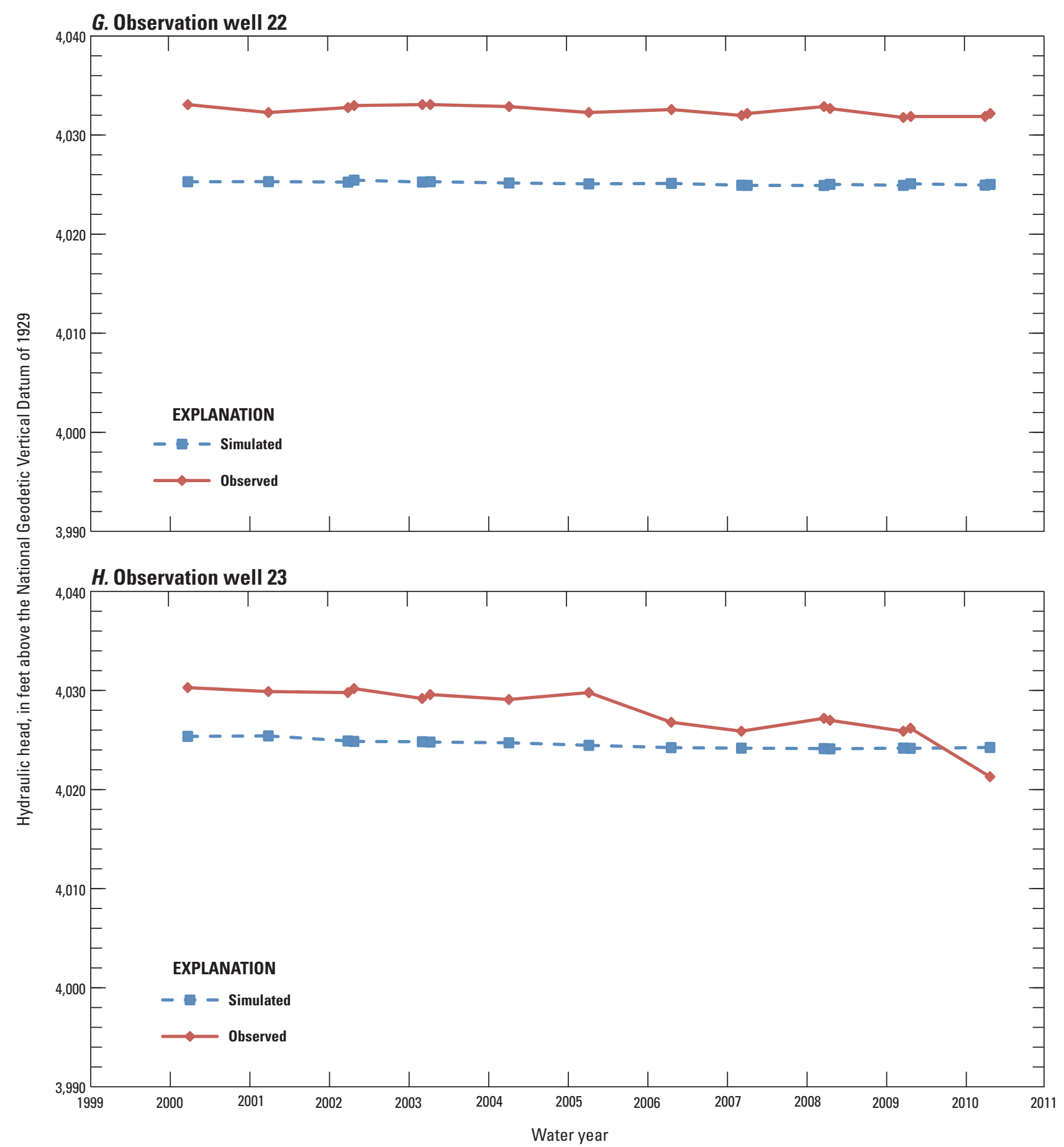

Figure A1.-Continued 


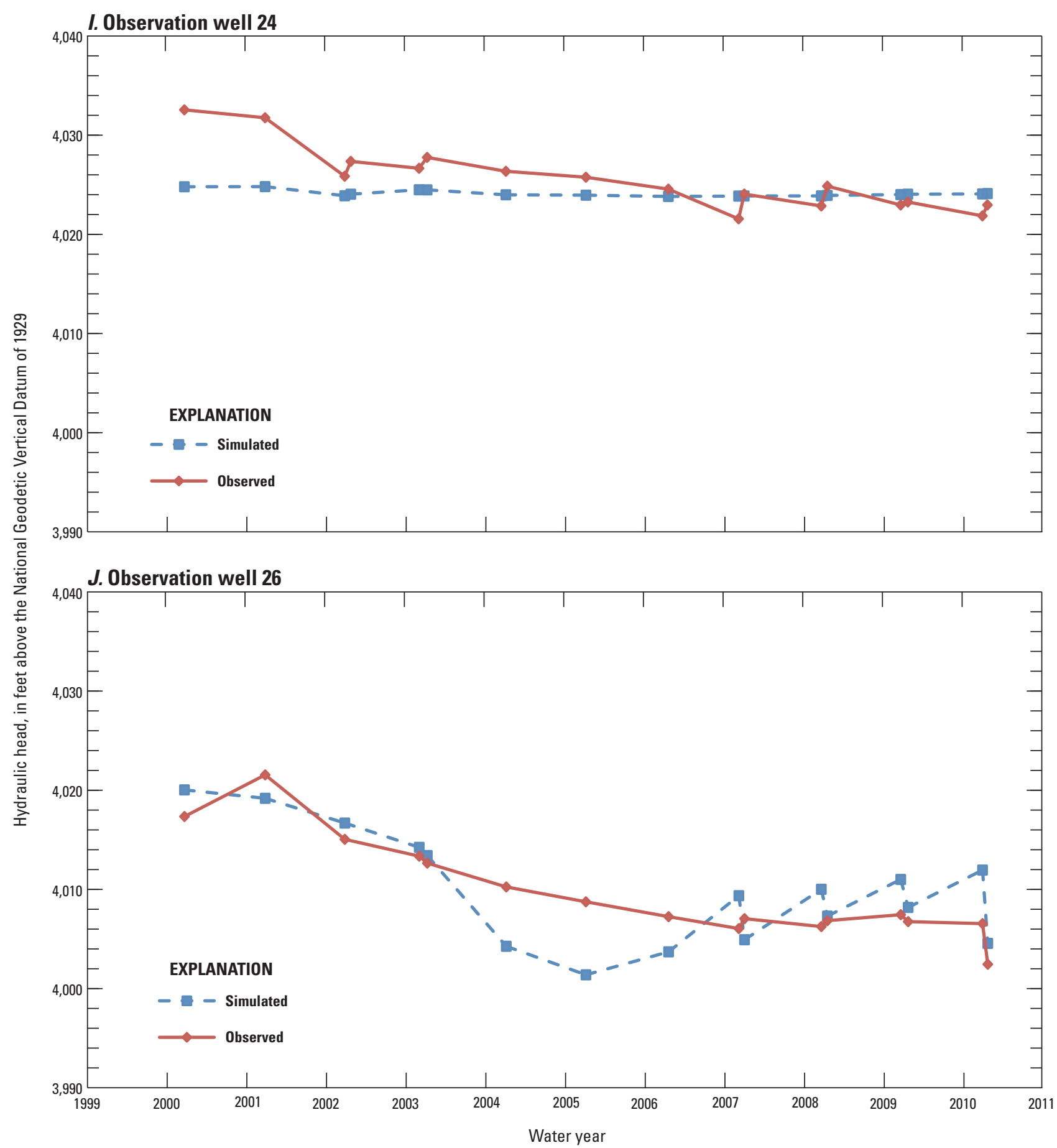

Figure A1.-Continued 


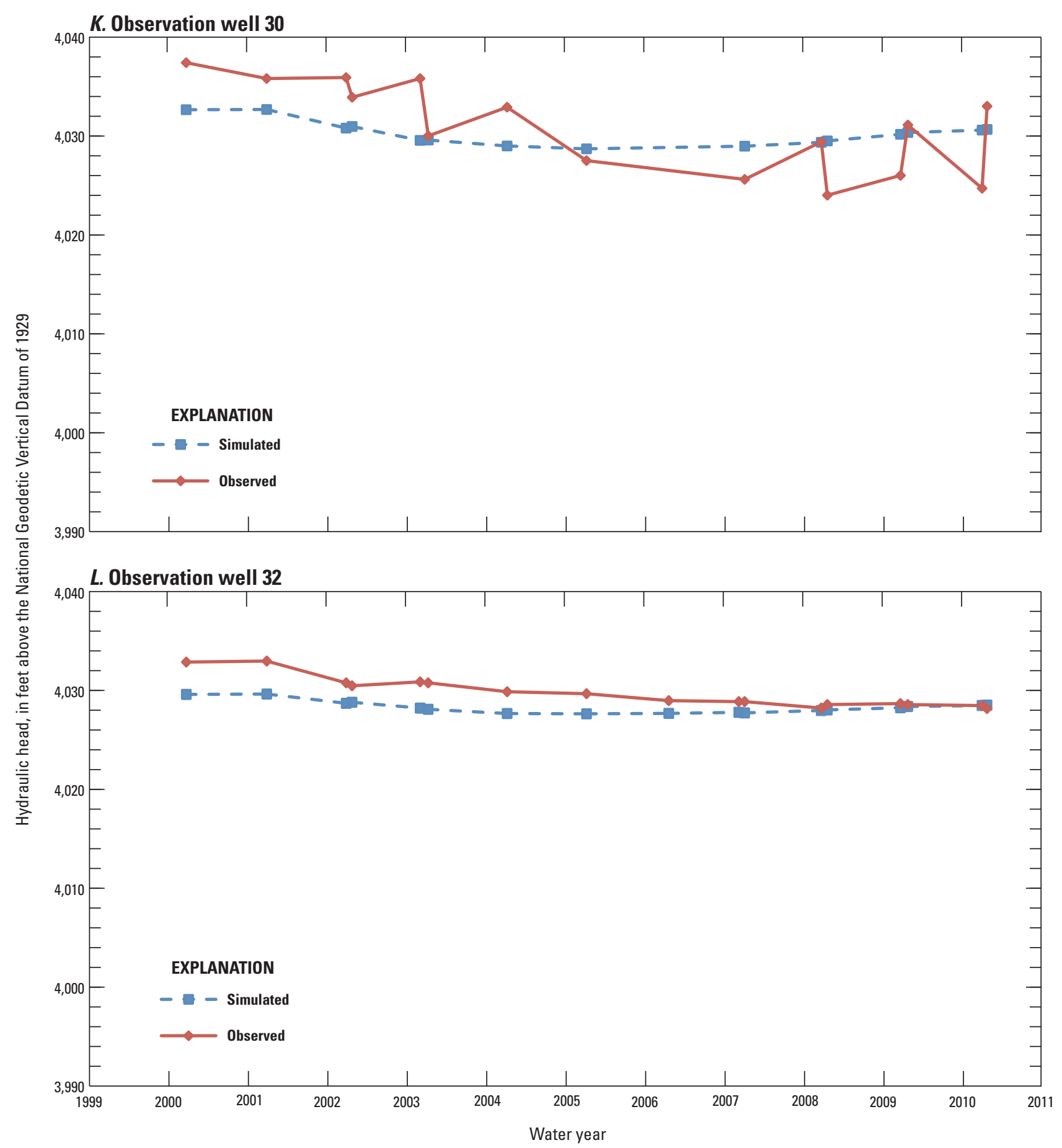

Figure A1.-Continued 


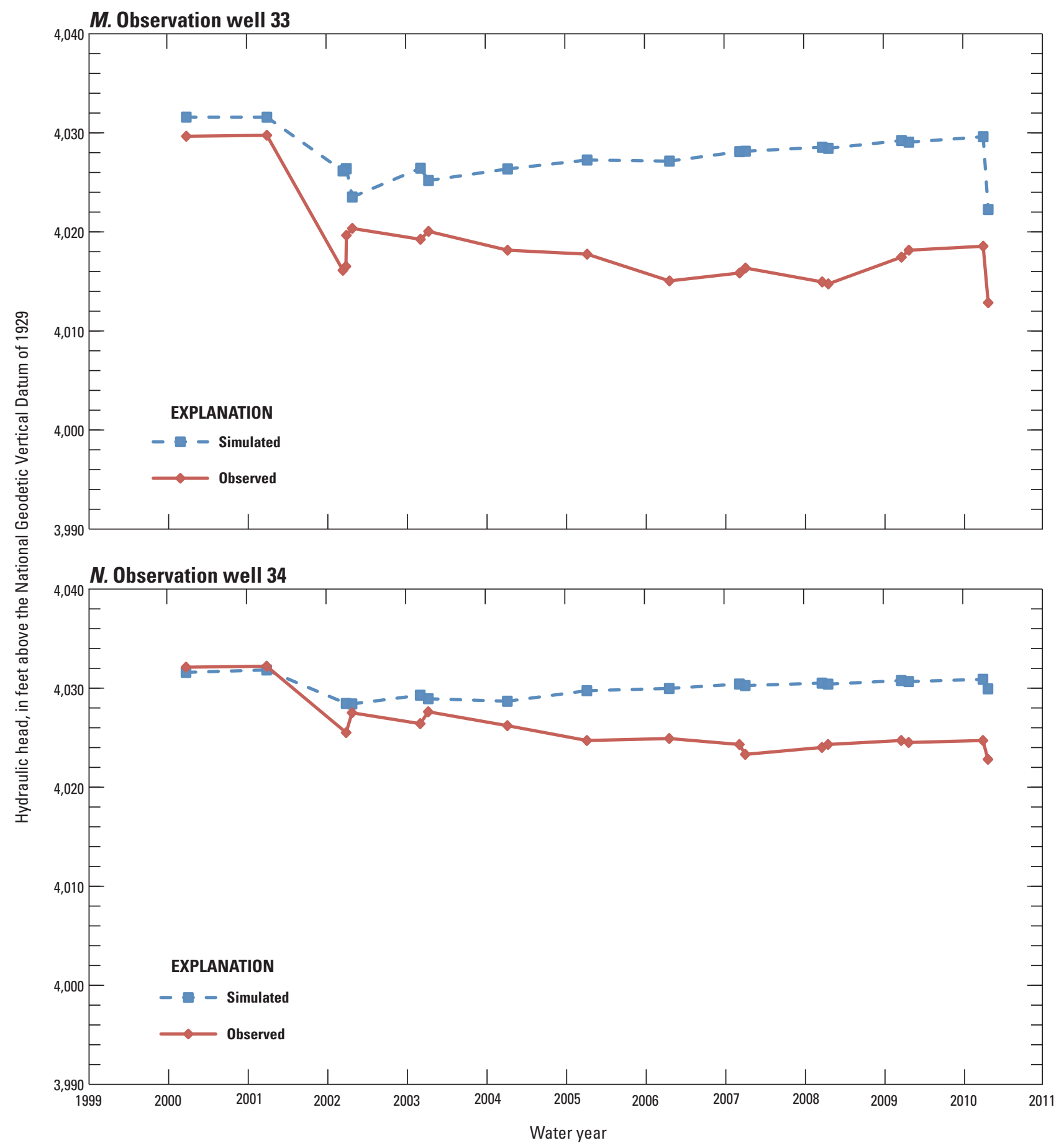

Figure A1. - Continued 


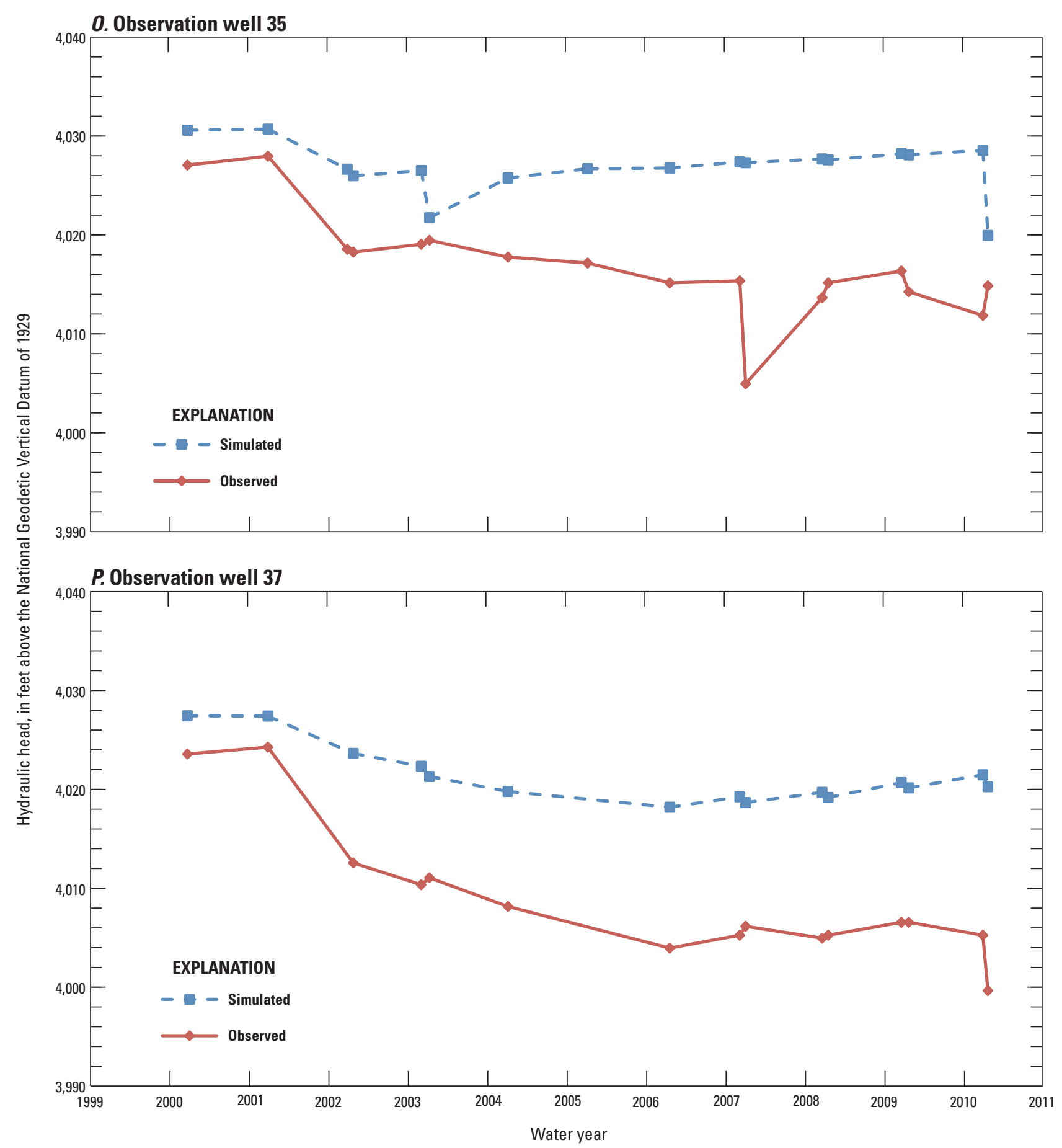

Figure A1.-Continued 
Publishing support provided by the U.S. Geological Survey Science Publishing Network, Tacoma Publishing Service Center

For more information concerning the research in this report, contact the Director, Oregon Water Science Center

U.S. Geological Survey

2130 SW 5th Avenue

Portland, Oregon 97201

http://or.water.usgs.gov 
음

a

을

苛

T

吾.

음

흠

言 